\title{
تأثير رياضة الدماغ على النظيم الذاتي لدى الأطفال ذوى صعوبات التعلم
}

إعداد

علا مُحَُّّ زكي الطيباني

أستاذ مساعد بقسم العلوم النفسية - كلية التربية للطفولة المبكرة- جامعة الإسكندرية

$$
\text { نشوة عبد الحميد يونس }
$$

مدرس بقسم العلوم الأساسية - كلية التربية للطفولة المبكرة- جامعة الإسكندرية

$$
\text { الإستشهاد المرجعى: }
$$

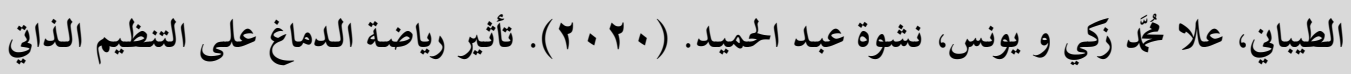
لدى الأطفال ذوى صعوبات التعلم. مجلة بجوث ودراسات الطفولة. كلية التربية للطفولة المبكرة، جامعة لئل

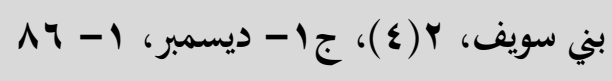


كلية التربية للطفولة المبكرة- جامعة بني سويف

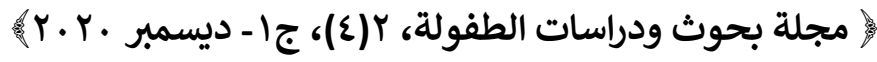




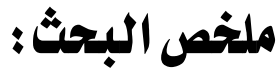

هدف البحث الحالي للتحقق من فعالية رياضـة الدماغ في تحسين التنظيم الذاتي لدى

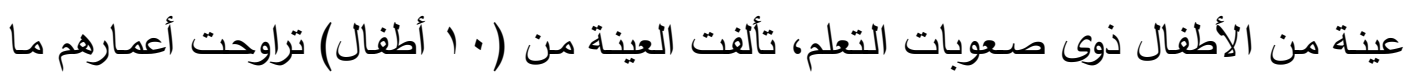

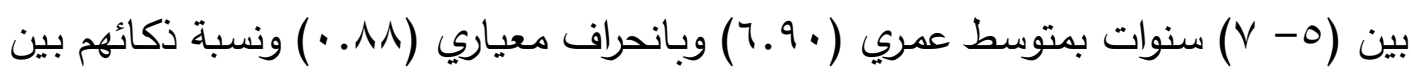

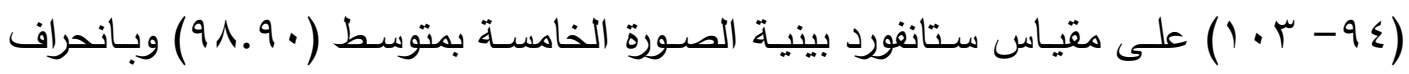

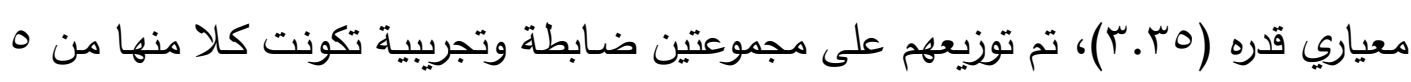

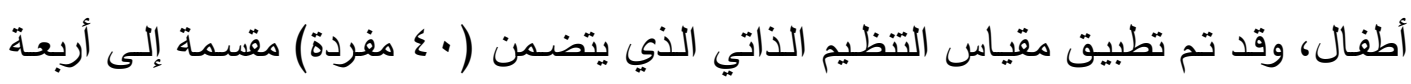
محاور هي مراقبة الذات، التخطيط ووضع الأهداف، التظظيم السلوكي، تقويم الذات (إعداد

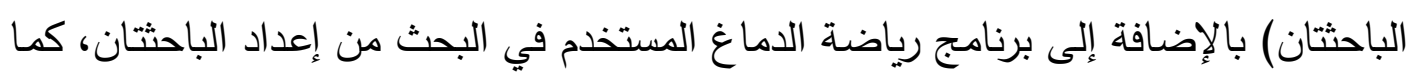

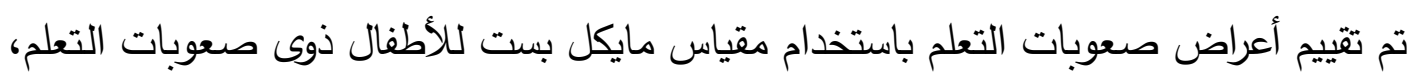
وقد أسفرت البحث عن وجود فروق ذات دلالة إحصائية بين متوسطات رتب درجات أفراد المجموعـة التجريبيـة قبل تطبيق البرنامج وبعده على أبعاد التتظيم الذاتي والدرجـة الكليـة

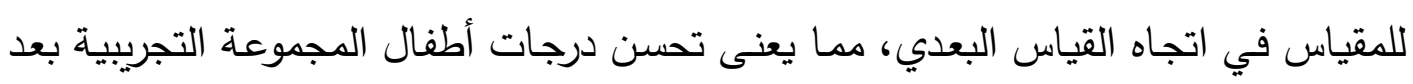

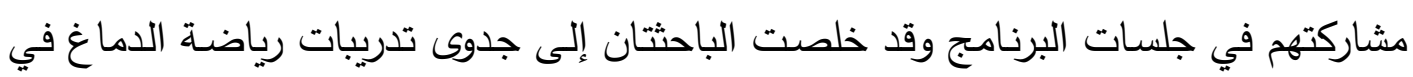

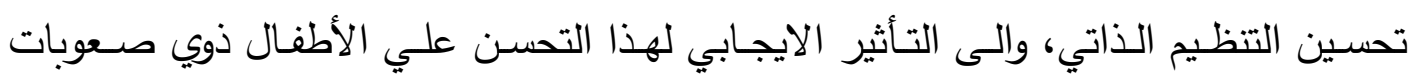

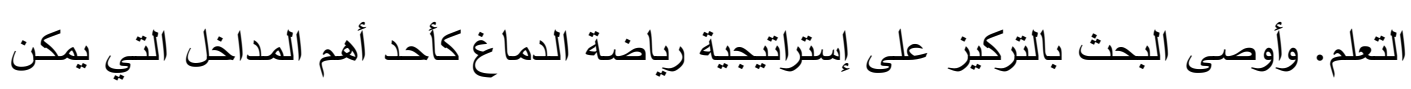
الاعتماد عليها في التدخل مع الأطفال ذوى صعوبات التعلم. الكلمات المفتاحية : صعوبات التعلم، التنظيم الذاتي، رياضة الدماغ 


\section{Abstract:}

The current research aimed to determine the effectiveness of a program based on brain gym in improving self-regulation of learning disabled children. The sample consisted of (10) children. Their ages varied from (5-7) years old, with mean average of 0.88 . Their IQ was (94 - 103) degree on Stanford Binet IQ test "fifth image", with mean average of 88.90 and standard deviation of 3.35. They were distributed into two groups: control and experimental. Each group consisted of (5) children. The sample was tested by the Self-regulation scale which consisted from 40 sentences, divided into (5) dimensions: selfmonitoring, planning, setting goals, organizing and self-evaluating (prepared by the researchers) and also the gym brain program used in the study (prepared by the researchers). Learning disabilities symptoms were evaluated by Michael Best scale for Learning disabilities. The results indicated that there are statistically recognized differences between the average ranks of experimental group pre - post program implementation on self-organization scale dimensions and the total scores in favor of post application. This indicates the improvement of children scores in the experimental group after participation in program sessions. The research suggested that the benefits of Brain gym exercises in improving self-regulation. They also have positive effect on improving the performance of children with learning disabilities. The research stressed the importance of focusing on brain gym strategy as one of the reliable methods in intervention programs for learning disabled children.

Keywords: Learning disabilities - self-organization - Brain gym 


\section{المقدمة والإطار النظري}

يُعد الأشخاص ذوى الاحتياجات الخاصة هم الأشخاص الذين يختلفون اختلافاً ملحوظاً

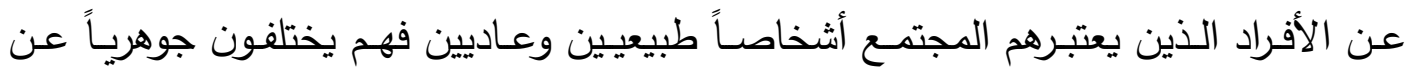
الأشخاص الأخريين في واحدة أو أكثر من مجالات النمو والأداء المعرفي والحسي والسلوكي واللغوي والتعليمي، مما يستلزم تقديم خدمات خاصة داعمة لهم يتسنى لهم تحقيق أقصى ما لها يمكنهم منه قداتهم وشعورهم.

أنّ الأطفال ذوي صعوبات التعلّم هم الذين يعانون من قصورٍ في واحدةٍ أو أكثر من

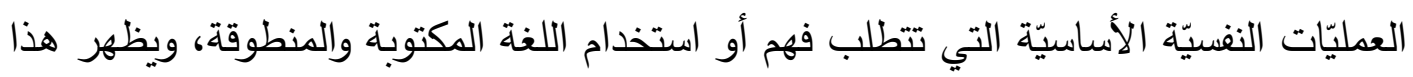

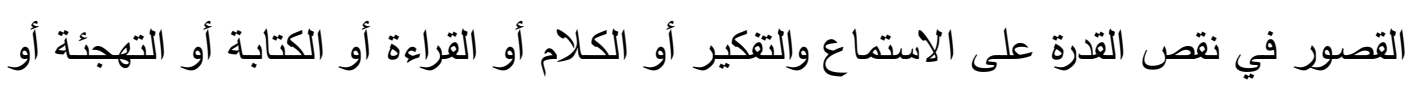

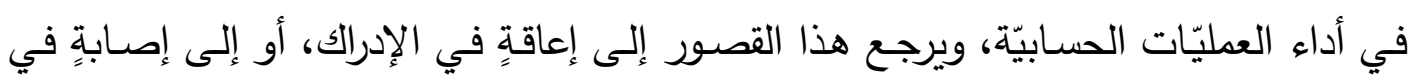

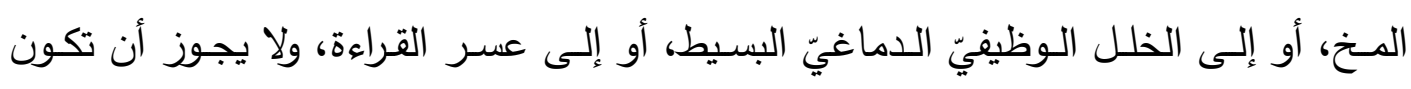

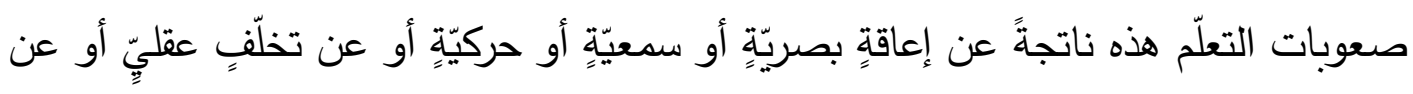

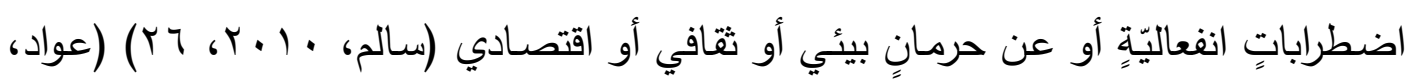
$\cdot(1 \cdot$. $4 \cdot 1)$

وذوو صعوبات التعلم Learning Disability هم أولئك الذين يمتلكون ذكاءً طبيعياً. ولكن لديهم صعوبة في القدرة على معالجة المعلومات وتختلف هذه الصعوبة من فرد إلى

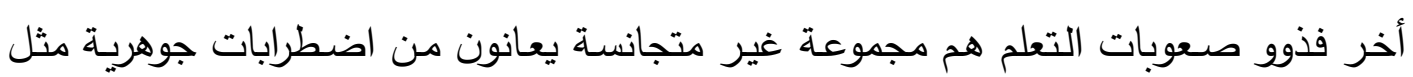

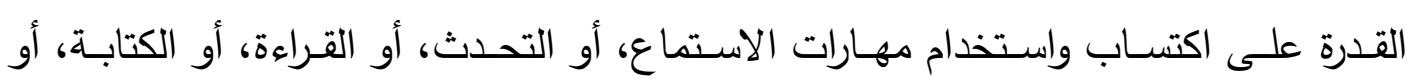
الحساب وهى ليست ناتجة عن عدم توافر فرص للتعليم أو أعاقة عقلية أو مشكلة حسية، ولا الا تظهر هذه المشكلات في جميع المجالات الأكاديمية ولكن في مجال محدد مثل القراءة 5

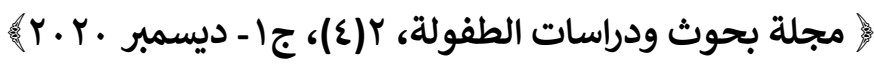




\section{كلية التربية للطفولة المبكرة- جامعة بني سويف}

والحساب (Reynolds, 2014, 1899). وتُعد مشكلة صعوبات التعلم من المشكلات الأساسية لاى الأطفال وخاصة في المرحلة الابتدائية، حيث يقدر نصف متلقي خدمات التربية

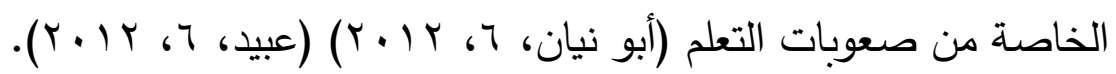

حيث يتسم الأطفال ذوى صسوبات التعلم بالذكاء المتوسط أو فوق المتوسط، ولديهخ العديـد مـن المشكلات الانفعاليـة والسـلوكية والاجتماعيـة وفقدان الدافعيـة، وضـفف التنظيم الذاتي، حيث تستتفذ جزا كبيراً من طاقتهم العقلية والانفعالية والمعرفية، ويؤثر هذا الضعف على عملية التعلم، وقدرتهم على بناء المعلومـات ومـا وراء المعرفـة وتعرضههم للرفض مـن الآخرين، كما يتعامل هؤلاء الأطفال مـع المشكلات إما عن طريق الانسحاب وعدم التفاعل مع الآخرين أو الانخراط في السلوكيات المشكلة والتي تفرغ ما يشعرون بـه من ضيق وتوتر .(Butler, 2015, 124)

خصـائص ذوي صسوبات التعلم: رغم اختلاف العلماء في تحديد خصـائص ذوي صعوبات التعلم إلا أنهم اتفقوا حول مجموعة منها يمكن حصرها في: مظاهر سلوكية: وتتمثل فيما يلي: - تدنى الانتباه وضعف التركيز مع شرود الذهن وسهولة التشتت. - صعوبة في الإدراك السمعي والبصري والحركي. - نشاط وحركة زائدة، لا يستقرون على وضع معين. - عدم التوازن في الحركة والمشي. - الفشل في إتمام المهام، فهو سريع التشتت.

يعد التعلم محور التقدم والتطور والحضارة وعدم التعلم يعني عدم حدوث تغيرات في السلوك إذ تشكل صعوبات التعلم مشكلة كبيرة ليست في مجال التعليم والمدرسة فقط بل هي

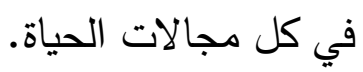


وظهور صعوبة في العمليات العقلية كالفهم والتفكير، والإدراك والذكاء التي تؤثر على القراءة والكتابة والاستيعاب ينعكس على الحياة الاجتماعية وطريقة التفاعل مع الناس، خاصـة إذا اتصف بالسلوك الانسحابي عن المواقف الاجتماعيـة وضعف التفاعل والمشـاركة وزيـادة الشعور بالخجل.

ومن خلال مـا تقدم نلخص إلى أن صعوبات التعلم أصبحت حالة اجتماعية تفرض على المجتمع وضـع حلول وطرق ووسـائل محاولـة منـه تقليل أو الحد مـن الظـاهرة (عواد،

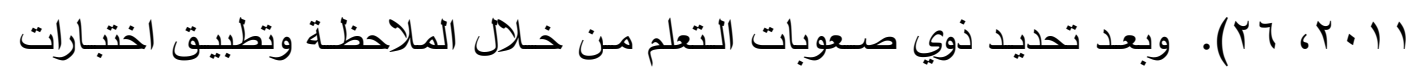
ومقاييس صعوبات التعلم على الطفل يمكن من خلالها تحديد نقاط الضعف، وأسبابها بهدف تحديد سبب المشكلة قبل محاولة حلها بوضـع برنامج مبدئي، وتحديد مدى استجابة الطفل للبرنامج بعدها يتم وضـع البرنامج النهائي، والذي سيتم تطبيقه على الأطفال ذوي صعوبات التعلم، كل طفل حسب إمكاناته العقلية.

تصنيف صعوبات التعلم: تعددت التصنيفات الخاصـة بصعوبات التعلم، فمن المتخصصين من أكد أن مشكلات القراءة والكتابة واللغـة تعتبر أسـاس لصسوبات التعلم، في حين ذكر آخرون أن صعوبات الانتباه، وتثتت الحركة هي الأساس.

ولقد أكد مصطفى (1 + . r) أن أشهر تصنيفات صعوبات التعلم هي صعوبات التعلم النمائية، وصعوبات التعلم الأكاديمية. وصـوبات الـتعلم الأكاديميـة: تعـرف بأنهـا اضــرابات القـراءة والكتابـة والمهـارات الحسابية. أما صعوبات التعلم النمائية هي الصعوبات التي تظهر في مرحلة الروضـة، لكون الصعوبات الأكاديمية تظهر بعد ذلك في المدرسة الابتدائية. 


\section{كلية التربية للطفولة المبكرة- جامعة بني سويف}

وتعرف صـوبات التعلم النمائية أنها اضطراب في الوظـائف والمهارات الأولية التي يحتاجها الطفل، بهدف التحصيل في المجالات الأكاديمية، وتظهر الصعوبات في مرحلة ما قبل المدرسة، وهي صعوبات تتعلق بالوظائف الدماغية، والعمليات العقلية، والمعرفية، ومنها:

$$
\text { - - اضطراب الانتباه. - اضطراب الذاكرة. - اضطراب التفكير. }
$$

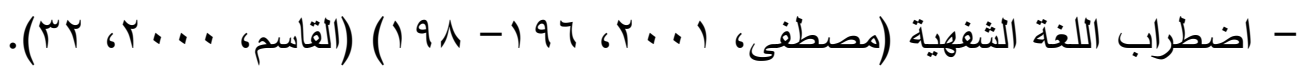
كمـا يواجـه الأطفـال ذوي صـعوبات التعلم العديـــــــ المشكلات عند بدايـة دخـولهم المدرسة، ودائمـا مـا يتم اكتشاف هذه الصعوبات من خـلال الاختبارات الإكلينيكية، ودراسـة الحالة، وغالبا ما يتم "إهمال دراسة الحالة النفسية لهؤلاء الأطفال؛ حيث نجد أن السمة الغالبة عليهم هي تدني اعتبار الذات، وكذلك العديد من المشكلات النفسية مثل الانعزال، والاكتئاب .(John W., Robert R., 2006, 3-10)

1- التنظيم الذاتي: هناك العديد من العوامل المؤثرة في صعوبات التعلم مثل الذاكرة والذكاء العام، والإدرالك البصـري، والإدراك السمعي، والفهم اللغوي، غير أن لقصسور التظيم الذاتي دوراً حيوياً في صعوبات التعلم الأكاديمية، فهو عملية توجيه ذاتي من داخل الطفل نفسه يقوم من خلالها بالمراقبة الذاتية والمثابرة والانتباه والإدرالك الواعي والقدرة على التحكم في التفكير والسلوك والانفعـالات لتحقيق الأهداف المنشـودة ومن ثم فـالمنظم ذاتياً يتحكم في جهوده ودوافعها ويحدد الأهداف التي يسعى إليها، والاستراتيجيات التي يستخدمها ثم يراقب سلوكه ويتأمـل ذاته، فالأطفال ذوى صـوبات التعلم الذين يعانون من قصسور في التتظيم الذاتي 


\section{كلية التربية للطفولة المبكرة- جامعة بني سويف}

يفشلون في معالجة المعلومات فهم أقل في الكفاءة المعرفية، مما يؤثر سلباً على النواحي

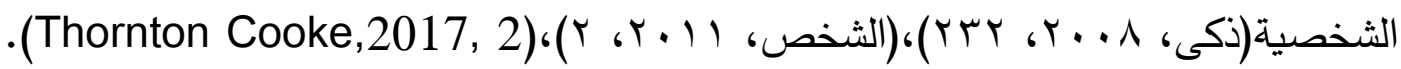

التنظيم الذاتي هو عملية توجيه ذاتي من داخل الفرد نفسه، يقوم من خلالها بالمراقبة الذاتية، والمثابرة، والانتباه والإدرالك الواعي والقدرة على التحكم في التفكير والسلوك والانفعالات للسعي لتحقيق الأهداف المنشودة ومن ثم فالثخص المنظم ذاتياً يتحكم في جهوده ودوافعه، ويحدد الأهداف التي يسعى إليها والاستراتيجيات التي يستخدمها ثم يراقب سلوكه ويتأمل ذاته .(Monteriro, 2015, 5) (Wong \& Butler, 2012, 148)

ويعرف التظظيم الذاتي هو الدرجة التي يمكن أن يكون بها الأطفال الانعكاس الذاتي ويمكنهم التخطيط والتفكير في المستقبل، ويتحكم الأطفال بهذه القوه في أفكارهم ويراقبون سلوكياتهم، ويقيمون قدرتهم على أداء الأشياء، ويضبطون سلوكهم، مثال ذلك إذا كان الطفل الذي يخضـع للتتظيم الذاتي يعلم أن هنـاك اختبـاراً قادمـاً فسيختار هـو أن يكـون مستعداً للاختبار بدلاً من الخروج مع أصدقاؤه.

أن التظيم الذاتي لـه قدرة على منع الاستجابات السلبية وتأخير الإشباع، فالفرد الذي لديـه القدرة على التحكم في ردود أفعالـه العاطفية تجاه المواقف الإيجابية والسلبية، كما في حالـة الطفل الذي يمكنهـ مقاومـة ميلـة الفوري إلى الغضـب عندما يتخطى نظيراً أمامـهـ في طـابور طلب الأكل، والتحسن في التنظيم الذاتي يؤثر علي النواحي الانفعاليـة والمعرفيـة والسلوكية والأكاديمية وحل المشكلات (Lens, 2008, 142)، (Greene, 2018, 3). التظظيم الذاتي لا يعتبر قدرة من القدرات العقلية ولا مهارة من مهارات الأداء الأكاديمي فقط إنمـا عمليـة توجيـه يـتم مـن خلالهـا توجيـه الطفل لقدراته العقليـة والأفكـار والمشـاعر 


\section{كلية التربية للطفولة المبكرة- جامعة بني سويف}

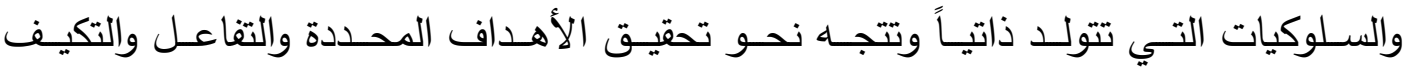
الاجتماعي.

وقد أضافت دراسة (2013) Felver إلى أن التظيم الذاتي لدى الأطفال يعد بمثابة منبأ لكل مـن التطـور الاجتمـاعي والانفعـالي والتكيف النفسي في مرحلـة الطفولـة المبكرة والمراهقة، كما يعتبر تنظيم الانتباه أمرا أساسيا في القدرة على التنظيم الذاتي للسلوك.

ولقد أكد كل من Bandy (2010), Jarvela (2011) على أهمية التنظيم الذاتي حيث انه ذو تأثير على قدرة الفرد لتحمل الرغبات المطلوبة والتعامل مـع الفشل وخيبة الأمل والعمل نحو النجاح ويمكن وصف التظظيم الذاتي باعتباره عملية يتم بواسطتها إعداد وضع الأهداف المستقبلية ومحاولة المراقبة الذاتية والتتظيم والتحكم في المعرفة والدافعية والسلوك

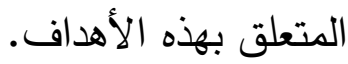

كما يمكن أن ينتج عن القصور في التنظيم الذاتي مستويات مرتفعة من الإحباط في المواقف التعليمية لأسباب مختلفة من أهمها مشكلات التذكر وضعف الانتباه وصعوبات أتباع التعليمات وصعوبات الإدراك البصري والسمعي، وتوقع الإخفاق بسبب خبرات الفشل المتكرة في الماضي وفى ضوء ذلك ثمة حاجة ماسة إلى تعليم هؤلاء الأطفال مهارات فعالة ومنظمة، تسـاعدهم على أن يصـبحوا متعلمـين ايجـابيين - كمـا تسـاعدهم على اكتسـاب المعلومـات وتعزيزها واستدعائها وتطبيقها في المواقف المختلفة (الخطيب، الحديدي، ؟ ا • ؟، ـ9- (9)، .(Bjork, Dunlosky \& Kornell, 2013, 22)

وكما أشار (eyva $(2015,776)$ إلى هناك تتوع في مهارات التنظيم الذاتي تثتمل على عمليات معرفية وسلوكية واجتماعية، وتركز العمليات المعرفية على تحديد الهدف، والقدرة على الاندماج، والمرونة المعرفية، وتحويل الانتباه، كما تركز العمليات السلوكية على 
مدى القدرة في التحكم في السلوكيات النشطة أو القدرة على التحكم في الانفعالات أو خفض أو إنهاء السلوك وتهدف العمليات الاجتماعية إلى مراقبة وتتظيم التفاعلات الاجتماعية

Ursache et al $(2012,181)$ Thirry $(2016,34)$ وقد أوضحت دراسة كل من أن هناك علاقة ارتباطيه بين التتظيم الذاتي والجوانب الإنمائية في مرحلة الطفولة المبكرة، خاصـة على النمو الانفعالي والاجتماعي والمعرفي حيث أن التفكير يؤثر على الانفعالات والانفعالات تؤثر على النمو المعرفي والأكاديمي فالأطفال الذين لا يستطيعون تنظيم القلق بفاعلية يميلون إلى الابتعاد على أنشطة التعلم، أن تتظيم الانفعالات يمكنهم من الاسترخاء والتركيز على مهارات التعلم المعرفية والذي بدوره يؤثر على الدافعية للتعلم وخاصـة أن مرحلة الطفولة المبكرة من المراحل التي يمكن فيها التنبؤ بالاضطرابات والمشكلات التي يمكن أن يتعرض لها الطفل فيما بعد فترتبط المستويات العالية من التتظيم الذاتي بالقدرة على أقامة علاقات جيدة مـع الآخرين وبالتالي التكيف مـع البيئة المحيطة كمـا أن التنظيم الذاتي يتنبأ بالنجاح الأكاديمي للأطفال. واكتساب التنظيم الذاتي يعتمد على عدة عوامل هي تقييم الذات ومراقبة الذات والقدرة على التخطيط والتنظيم وجميعها مناطق نقص أو قصور للى الأطفال ذوو صـوبات التعلم، وتعتبر فترة الطفولة المبكرة والمتوسطة من الفترات الهامـة في حياة الطفل لما لها من أهمية في تعزيز مهارات التظيم الذاتي، حيث تسهل مهارات التنظيم الذاتي القدرة على التركيز على الأهداف المحددة - والاسـتجابة الصـحيحة والايجابيـة للمثيرات الانفعالية والمعرفية، كما انه من خلال التنظيم الذاتي يستطيع الطفل التحكم والتتظيم الفعال في انفعالاته وإدراكه وسلوكياته، ويتضمن التنظيم الذاتي عمليتان رئيسيتان أولهما التحكم في الانتباه كالقدرة على حل النازعات، وعدم التشتت في مثيرات أخرى، والثاني تنظيم الانفعالات (Zimmerman, 2009, 249), كالقدرة على التعبير عن الانفعالات والسيطرة عليها .(Gross, 2007, 4), (Tuncay, 2019, 27) 


\section{كلية التربية للطفولة المبكرة- جامعة بني سويف}

ويمكن تقسيم أبعاد التنظيم الذاتي إلى أربعة أبعاد سوف تعتمد عليها الباحثتان في بناء البرنامج لذوى صعوبات التعلم، وذلك بعد الإطلاع على الأدب النظري للتنظيم الذاتي، وهى: r - مراقبة الذات Self Monitoring: في هذا البعد يتعلم الطفل كيف يلاحظ ذاته ويراقب أفعاله ويعطيها الأهمية الكافية للتعامل معها وتحليلها، وتثمل تركيز الانتباه والمراجعة من خـال فهمـه لمـا يدور حوله، وهـى من أكثر التقنيات دقـة وأهميـة في التتظيم الذاتي، يتعلم الأطفال مراقبة أخطاؤهم، ويتعلمون تفقد استجاباتهم ويصبحون واعين لأخطائهم واستجاباتهم .(Panadero, Klug\& Järvelä, 2016, 723) (Dembo\&Seli, 2013, 3) ويعرف إجرائياً "بالدرجة الكلية التي يحصل عليها الطفل علي فقرات مراقبة الذات في

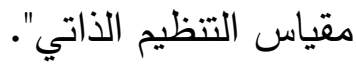

r- التخطيط وتحديد الأهداف Planning: وأشار (Dawson \& Guare، 2009، 231) إلى أن التخطيط هو القدرة على عمل خارطة طريق للوصول إلى هدف أو إكمال مهمة فضلا عن القدرة على اتخاذ القرار حول ما هو هام والتركيز عليه أولا. والتخطيط وتحديد الهدف يساعد الأطفال على تحفيز الأداء وتزيد الدافعية، وتبنى جهود الأطفال ومهمة في التنظيم الذاتي، وتعمل على توفير المعلومات، وأكثر الأهداف مناسبة للأطفال ذوى صعوبات التعلم هي الأهداف المعياريـة محددة المعيـار، قريبة المدى، وتتحدى القدرات بمستوى الصـعوبة، شـريطة الواقعيـة، لان مثل هـذه الأنـواع مـن الأهـداف قـد تعـزز الكفــاءة الذاتيـة والتحفيـز .(Wong\& Butler, 2012, 149)

ويوصى (2011, 35 بأهمية تدريب الأطفال في سن مبكر على التخطيط، وتجزئة المهام الكبيرة إلى سلسلة من الخطوات الصغيرة وتحفيز الطفل على تنفيذ كل خطوة وتبدأ بمهام صغيرة مثل المساعدة في التجهيز لرحلة أو كيفية قضـاء 


\section{كلية التربية للطفولة المبكرة- جامعة بني سويف}

العطلة، كما يجب على الآباء التخطيط أمام الأطفال لكي يكونوا نموذج يحتذي به، وعمل قوائم كمتابعة الأطفال، وتقديم نماذج مختلفة للخطط وكيفية تنفيذ خطواتها. ويعرف إجرائيا "بالدرجة الكلية التي يحصل عليها الطفل علي فقرات التخطيط ووضع الأهداف في مقياس التنظيم الذاتي". ؛ - التنظيم السلوكي Behavioral regulation:

أن التظيم هو القدرة على وضع ترتيب مسلسل للأنثطة المطلوبة لإنجاز المهام، في خطوات متسلسلة متفاعلة، ويؤدى الاضطراب في التنظيم إلى تداخل مربك لحل المشكلات

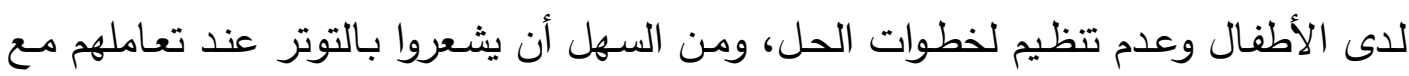
المشكلات المركبة بهدف حلها.

وتعليم الطفل التنظيم أمر ضروري لنجاحه في المدرسة وفى الحياة اليومية وذلك بما يضـمن لـه تجميع وتخزين المعلومـات بطريقـة فعالـة يستطيع استرجاعها عندما يحتاجها ويستطيع التعبير عنها بسهولة، كما يجب التواصل مع المعلم وتعريفه بهذا النظام وتدريب الطفل عليه وعمل ملف خاص بالواجبات المدرسية والأنشطة المطلوبة من الطفل وعمل تقييم دوري للتعرف على مدى استخدام الطفل لهذا النظام ويمكن استبدال هذا النظام أو التعديل فيه، يجب استخدام المصنفات أو الصور لتركيز البصري للطفل والتعرف على أي مكان

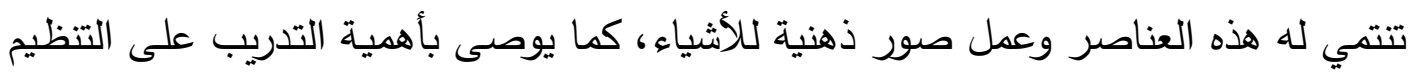

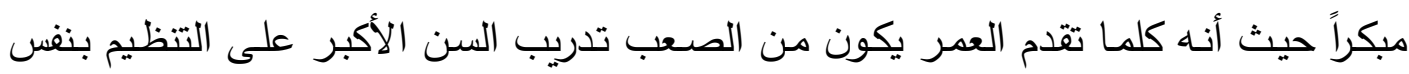

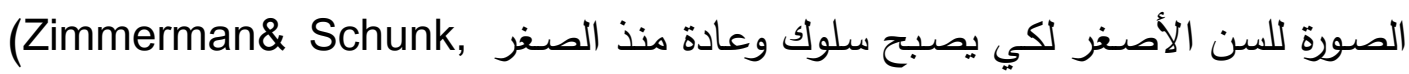
$.2011,33)$ 


\section{كلية التربية للطفولة المبكرة- جامعة بني سويف}

ويعرف إجرائيا "بالدرجة الكلية التي يحصل عليها الطفل علي فقرات التظيم السلوكي في مقياس التنظيم الذاتي".

$$
\text { ه - تقويم الذات Self - Evaluation: }
$$

تعد بمثابة المراجعة المنتظمة لما تم إنجازه وتثبيته من سلوكيات صحيحة، ويقارن بين المعلومات التي تتم مراقبتها ذاتياً مع الهدف أو معيار ) التقويم الذاتي عملية أساسية في تقييم الأهداف ويمكن للأطفال الاختبار بين عدة معايير لتقييم مدى كفاية تعلمهم وأدائهم ويرتبط بالمراقبة الذاتية، ويتطلب من الأطفال تقييم فترات سلوكية كان يقوم الأطفال (Zimmerman, 2008, 186). ويُعرف إجرائياً "بالدرجة الكلية التي يحصل عليها الطفل علي فقرات تقويم الذات في

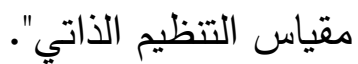

وتظهر مشكلات التظيم الذاتي لدى الأطفال ذوو صعوبات التعلم في صورة صعوبة في الاستمرار في الأنشطة إلى الانتهاء منها والسيطرة على السلوكيات وانتظار الدور وتتبع المهام التي يقوم بها، وتخطيط وتوجيه الأهداف نحو ما يريد فعله - Harris, 2012, 142) .(Santangelo, 2007, 1, 16) 143)

ويحتاج الأطفال ذوى صعوبات التعلم لتدعيم التنظيم الذاتي حيث أنهم يملكون العديد من التحديات التي تحتاج إلى التنظيم الذاتي، على سبيل المثال فهم يواجهون مشكلات في القراءة والفهم القرائي والكتابة والحساب، كما يعانون من مشكلات في التخطيط ومراجعة ما تم (Wong\&Butler, إنجازه وتحديد أهدافهم، مما يؤثر على مهارات التحصيل الأكاديمي 
استراتيجيات التنظيم الذاتي: - n

لقد توصل كل من (Tuncay, 2019, 9) (Milligan, 2015, 562) إلى أن

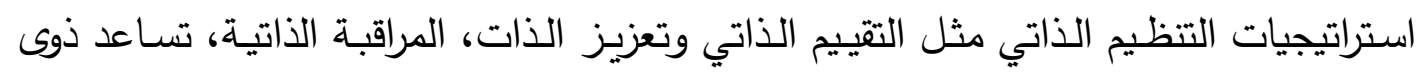

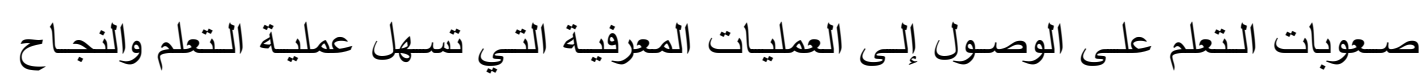

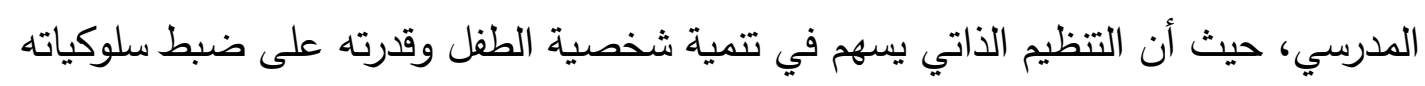

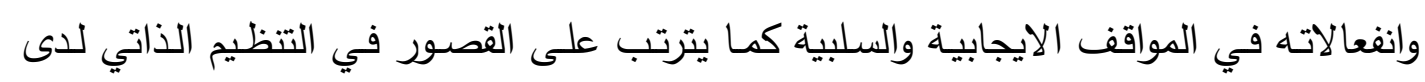

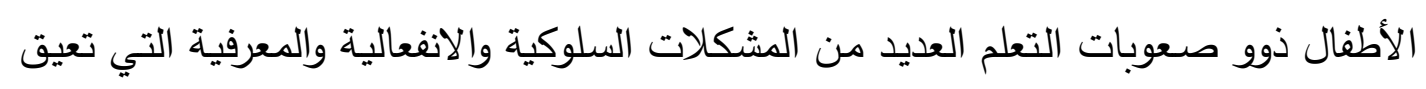
بدورها تفاعل الطفل مع البيئة المحيطة به ومن ثم النجاح في التكيف الاجتماعي. ووجد أن هناك تداخل في العلاقة الارتباطية بين التتظيم الذاتي والأداء الأكاديمي

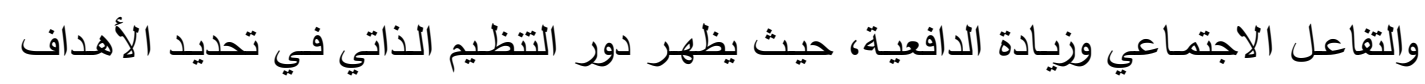

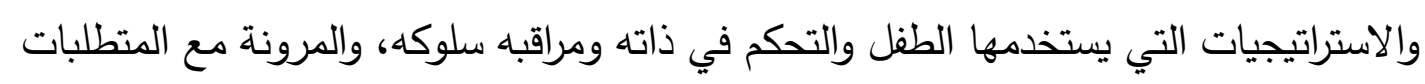
الاجتماعية التي يواجهها يومياً كما انه يمتلك علاقات اجتماعيه ناجحة وقدرة على النجاح

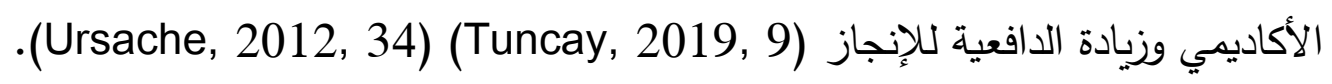
مما سبق تظهر أهمية تعليم الأطفال ذوي صعوبات التعلم التظظيم الذاتي في سن مبكر حيث يؤثر ذلك على الوظائف في شخصية الطفل ويدعمها بشكل إيجابى مثل الانتباه والتخطيط وحل الشكلات، الذاكرة، كما يساعد أيضا في إدارة الوقت، يساعد تعليم التنظيم

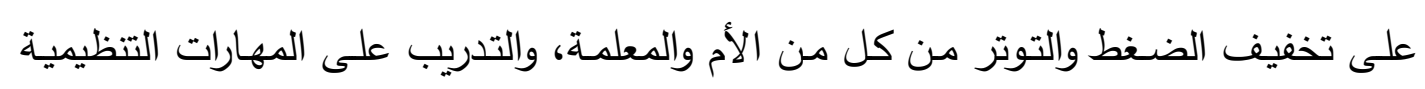

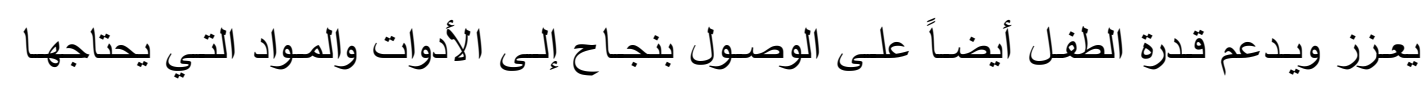

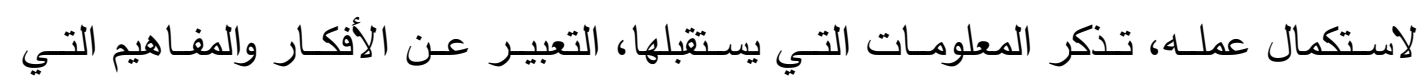

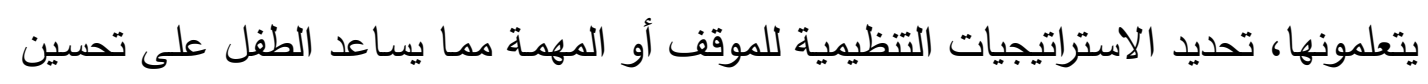

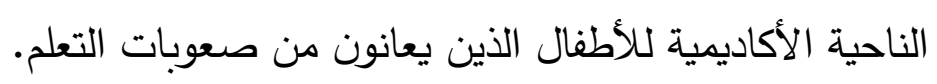




\section{كلية التربية للطفولة المبكرة- جامعة بني سويف}

رياضة الدماغ Brain Gym: (رئ

أن مرحلـة الطفولـة المبكرة مرحلـة هامـة للتعلم حيث أن جزء كبير من دماغ الطفل يتكون في هذه المرحلة، فيحتوى الدماغ على مليارات الخلايا العصبية، فيقوم الدماغ في

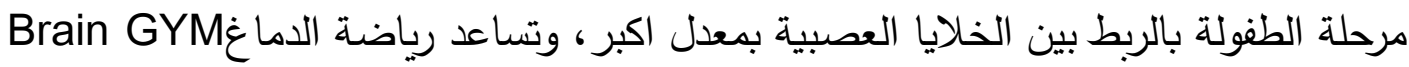
على زيادة الروابط العصبية مما يعمل على تحسين وظائف المخخ ) (Howard, 2007, $)$ .(Lengel, 2010, 6)

Coch (2009), Fischer (2009), Ellis \&Newton (2010) ولقد أوصي كل من على أهمية وعي المعلمون بمعرفة الدماغ وكيف يؤثر علي التعلم في عمر مبكر ، ومعرفة أهم الاستراتيجيات التي تعمل علي تحفيز الوصلات العصبية وزيادة تثابكها حيث أن الأطفال مبكراً تكون استجاباتهم سريعة، ومعالجتهم للمعلومات تكون أفضل. والأطفال الذين يشاركون في أنثطه وتجارب تعتمد على الحركة في عمر مبكر ، يعمل ذلك على زيادة وتفعيل الوصـلات العصبية لديهم، مما يؤدى إلى شخصيه متعلمة ايجابية

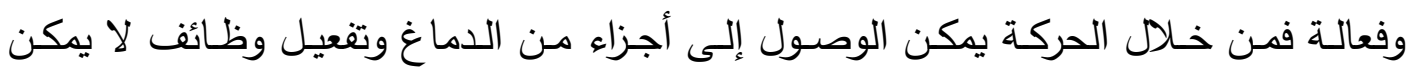
الوصول لها بأي استراتيجيه أخرى (Kubesch et al., 2009, 238).

وتستتد تدريبات رياضه الدماغ Brain GYM نظريات علم الحركة التربوي وعلم الأعصاب، فهو عبارة عن سلسلة من الحركات البسيطة والمتكاملة والمتقاطعة التي لها أساس لهاس في علم الأعصاب وتعمل على تتثيط كلا نصفى الدماغ التي يمكن للمعلمين استخدامها لتعزيز خبراتهم في تعلم الدماغ بالكامل، حيث أن معظم مشاكل التعلم تحدث عندما لا يكون

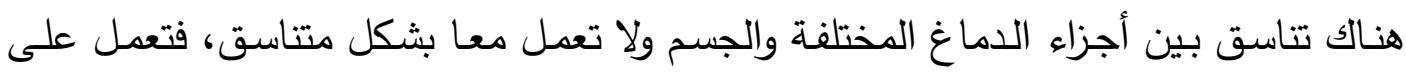
تتشيط التشرة الحسية، وتحفيز النظام الدهليزي لتحقيق التوازن، كما أن هذه التدريبات تساعد

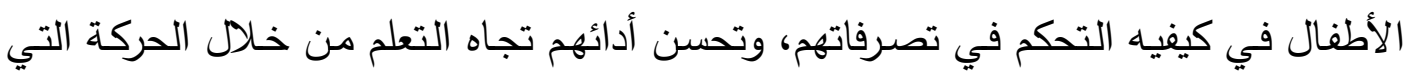


تستخدم الدماغ بأكمله للتكامل بين كل من الجسم والدماغ، مما يؤدى إلى تعلم أكثر سهولة وفعالية، حيث تقوم بتنسيق الجسم كله بما في ذلك العينين واليدين، وتتكون من بr حركة، تساعد فبزيادة التركيز وتعزيز الذاكرة والجوانب الأكاديمية، والمهارات التتظيمية، والاتجاهات

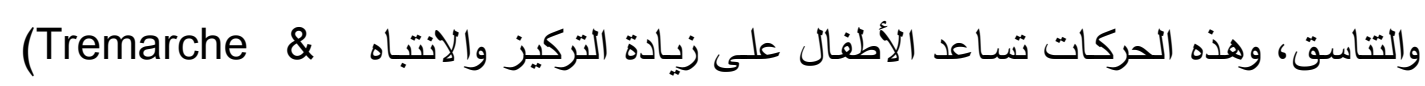
.Graham, 2007, 99), (Flatin, 2012, 13)

كما يحقق التواصل بين أجزاء الدماغ المختلفة والتوازن والتتظيم بين الناحية العقلية والناحية الانفعالية فيعمل على تقليل الاندفاعية، كما يعزز الناحية المعرفية والأكاديمية، كما تعمل أنشــة رياضــة الـدماغ أيضـاً على التطـور العصبـي والاسـتعداد للتعلم في جميـع

الأعمار (Bennison\&Dennison, 2010, 7), (Brain gym Website, 2005, 4).

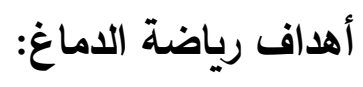
أن أنثطة رياضـة الدماغ تهدف لتحسين الناحية الجسمية والعقلية كمـا أنها تستخدم أيضـاً لتحفيز وتهائـة الأطفال في المواقف التعليمية المختلفة، ولان النشاط البدني والحركي يعززان وظائف المخ وينتج عنهما فوائد كثيرة للنمو المعرفي، كما أن النشاط البدني ليس مفيد فقط للصــة البدنيـة ولكن أيضــاً مفيد للوظـائف الإدراكيـة خاصــة، ويمكن أيضـاً تحسـين الوظائف التنفيذية التي ترتبط ارتباطاً وثيقاً بتحقيق التعلم من خلال النشاط المركز والمتكرر (Brown, 2012, 160); (Kubesch, Walk, (Spaulding, 2010, 66) والمستمر .2009, 237);

وتعمل رياضــة الـماغ علـي زيـادة المهارات السـلوكية ومستوي الفهم الإدراكي، فقد توصـلت نتـائج الدراسـات أن هنـاك زيـادة في الفهم الإدراكي، وتحسـن في مسـتوي الأداء

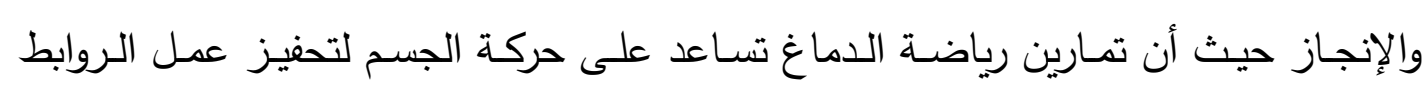




\section{كلية التربية للطفولة المبكرة- جامعة بني سويف}

العصبية بشكل متوازن حيث أن وسط الدماغ يقع في منطقة مقابلة لجميع الجوانب التي تعمل بانسجام وفى بعض الأحيان لا تعمل هذه الجوانب، بشكل متوازن ومنسجم وذلك بسبب التأثر بأحد العوامـل كالتوتر والضـغط في هذه الحالـة يصبح للرياضــة الدماغ دور مهم في قيام الأثخاص بالحركات الجسمانية المختلة بسهولة، بالإضـافة إلى تدفق المعلومات من مراكز (Peterson, 2002); (Wolfsont, 2002, 5) (الدماغ مما يؤدى إلى تحسن الأداء كما أضـافت Hannaford $(2005,121$ أن تمارين رياضـة الدماغ تساعد الأطفال على خفض السلوكيات السلبية، وتعزيز الوعي بالذات كما تعمل كمحفز للأطفال وتخفيف التوتر والإحباط الناتج عن الضغوط الصفية، فيعتبر وسيلة لتعزيز وقت الطفل في المهمة، والتحكم الذاتي، حيث أن الدماغ البشري يحتاج إلى أكسجين وماء للدعم عميلة التنكير في التعلم وهذا تقوم علية تدريبات الدماغ.

Brain وإذا كانت الحركة والأنشطة البدنية توقظ الدماغ فان تدريبات رياضـة الدماغ gym تذهب إلى أبعد من هذا، فهي تقوم باستثارة كلا من جانبي الجسم والتآزر والتتاسق بين كـلا مـن العينين واليدين، كمـا تتمى العمليات العقلية كـالتركيز والانتباه والتتكير والإبـداع، فتـدريبات رياضـة الدماغ تتشط النظـام النفسي فسيولوجي وتهيئ الطفل للتعلم عن طريق حركات بسيطة وسـهلة التطبيق وهذه الحركات هامسة في عمليـة التعلم حيث يقوم بإيقاظ وتنشيط عدد من إمكانياته العقلية (Hannaford, 2011, 16, 120). كما ينظر إلى الأنشطة الفعالـة والمتوازنـة التي تحث عليها رياضــة الدماغ على أنها لا يتجزأ من برنـامج شامل للتطوير الذاتي والذي يعمل على تحقيق التوازن بين الحركة والتعلم بشكل منسجم كما على تحدى واجتياز أي صعوبات في التعلم وبالتالي التقدم بشكل أفضل نحو الهدف المنشود .(Hyatt, 2007, 118) 


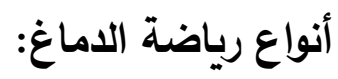

ورياضة الدماغ أربعة أنواع مختلفة حيث يشمل هذا التتوع تنشيط أكثر من جانب من الجسم، ويشمل بعضها التكامل بين كل جزء والجزء الأخر مثل:

تمرينات حركة خط الوسط Midline Movement: ويركز هذا النوع من التدريبات على تتشيط كل من الجانبين الأيسر والأيمن مما يساعد على تتشيط جانبي الدماغ

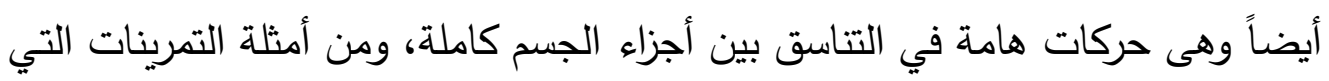
تعزز هذا الجانب الزحف المتقاطع والتنفس البطني. تمرينات الإطالة Lengthening Activities: وتساعد المخخ على عمل روابط بين ما يعرفونه في الجزء الخلفي من الدماغ والقدرة على معالجة المعلومات في مقدمة الدماغ

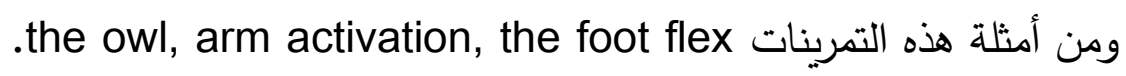

تمرينات الطاقة The Energy Exercises:

تمرينات المواقف المتعقة Deeping Attitudes التي تعدل على زيادة وتتشيط الروابط العصيبة بين أجزاء مختلفة من الدماغ والجسم، كما تعمل على تتشيط معالجة المعلومات (Official Brain Gym Website, 2009 (Dennison, 2010).

ولقد أضاف Berninger \& Richards $(2009,15$ أن هناك اتصالات وتبادلات

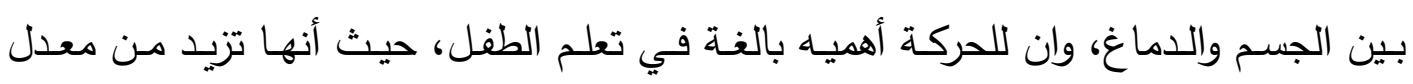

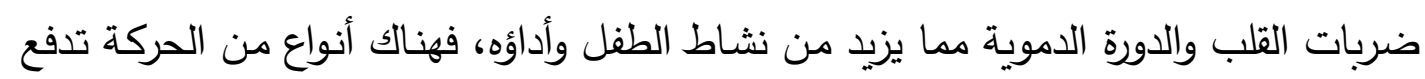

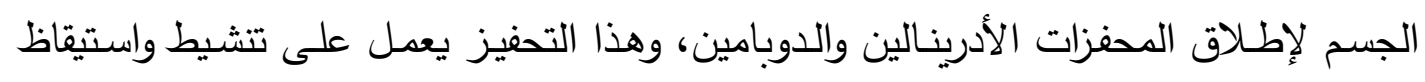
الدتعلمين وزيادة مستوي الطاقة، وتحسين تخزين المعلومات الخاصة بهم واسترجاعها أيضاً، فالجلوس الكثير يؤدي إلى عوامل خطرة منها التوتر والتعب في الجسم، وضعف التتنس. 


\section{كلية التربية للطفولة المبكرة- جامعة بني سويف}

وبمعرفـة أهداف وأهميـه الحركـة بالنسـبة للطفـل، والتـي تتمثل في استعادة انتبـاههم وتركيزهم وتعزيز قدرتهم على التعلم، كما أنه يمكن استيعاب الكثير من المعلومات وتتشيط الذاكرة، كما أن للحركة مجموعه من الأهداف منها تحضير وتجهيز الدماغ، حيث أن الطريقة التي يفكر بها الأطفال ويتعلمون بها تتأثر بشكل مباشر بالنشاط الجسدي، كما أن الحركة Epema,2010,7; تعمل على توفير استراحات للمـخ مما يساعد على تتشيط الأطفال .(Flatin, 2012, 18

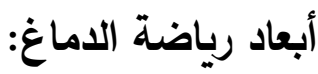

تتضمن رياضـة الدماغ ثلاثة أبعاد رئيسية تهدف إلى تحقيق التكامل في عمل أجزاء

$$
\text { الدماغ المختلفة وهذه الأبعاد هي: }
$$

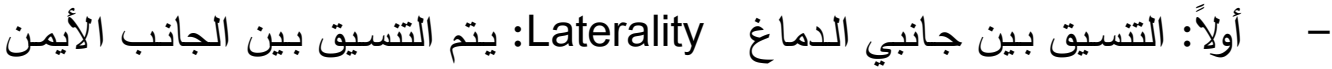
والأيسر للـدماغ والذي يعتبر ضـرورة ملحـة للقيـام بمهارات مثل القراءة والكتابـة والاستماع والمحادثة والمقدرة على الحركة والتركيز فئ نفس الوقت. - - ثانياً: التركيز Focusing: حيث يتضمن التتسيق بين الجانبين الأمامي والخلفي للدماغ ويرتبط هذا البعد بالمقدرة على الفهم وصعوبة القدرة على الانتباه والتركيز . - - مالثاً: التوسيط Centering: ويعمل هذا البعد على ربط الأجزاء العليا والسفلى لللدماغ كما يرتبط بالتوازن العاطفي (Brain GYM, 2016, 71). كما أوضحت (Hannaford,2005,79) أن هناك علاقة تكاملية بين كل من الجسم والدماغ، التي أجريت على الأطفال ذوى صسوبات التعلم، على افتراض مفاداة أن التعلم والتفكير والذكاء هي عمليات للجسم كله وليس فقط للدماغ وحدة، فيلعب جسمنا دورا مهما في جميع عملياتتا الفكريـة منذ الولادة وحتى الموت، فيتكون فهمنـا للعالم ممـا يستثعره جسمنا 
ويتغذى علية عليه الدماغ وحركتنا تزداد تعقيدا لأنها تعبر عن المعرفة وتساعد على اكتساب

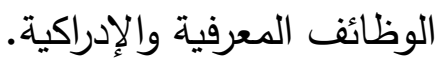

\section{وتقوم رياضة الاماغ على ثلاث أسس نظرية:}

- أولها: إعادة القولبة العصبية Neurological Re- patterning: يعتمد هذا الجزء على Domain Delacato العديد من النشاطات المرتكزة على ما يسمى بالحساسية للمجال والتي ترى بان على الطفل أن يتقن مهارات الحركة خلال المراحل المختلفة لنموه. ولكن إذا

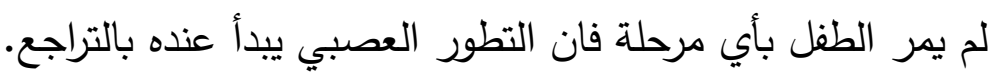
- ثانياً: السيطرة الدماغية Crerbral Dominance: يقوم هذا الافتراض على أن تفاوت واضطراب السيطرة الدخيـة هو السبب الرئيسي والمسئول عن نقص الانتباه وصسوبة

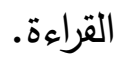

- ثالثا: التدريب الإدراكي الحركي Perceptual- Motor Training: يقوم هذا الافتراض

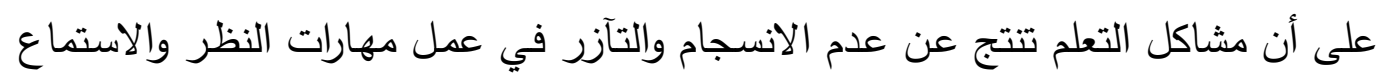
والحركة (التآزر البصري السمعي الحركي) وبالتالي فان هنالك بعض الاستراتيجيات التي تم وضعها لتعليم مهارات حركية مثل الزحف ورمى الكرة والمشي على الخط أو دعامة متوازنة وغيرها من الحركات (Bennison \& Dennison, 2010, 3); (Brown, 2012, 7).

وقد خلصت الدراسات إلى أثر التدخل القائم على رياضـة الدماغ في تسهيل عملية التعلم وتعزيز التحكم الذاتي، وزيادة المرونـة العصبية بما تعمل على تثكيل الجسور التي تربط بين الجسم والدماغ، وتتكامل عمل وظائف الدماغ مع حركات الجسد، مما يساعد على تذكر الطفل للمفاهيم لفترة أطول، فالحركة تجعل عملية التعلم أكثر كفاءة وتثرك الدماغ بأكمله لفهم المفاهيم، حيث أن رياضـة الدماغ طريقة فريدة ومتميزة لأننا من خلالها تمنح 


\section{كلية التربية للطفولة المبكرة- جامعة بني سويف}

المتعلمين حافزاً قوياً للتقدم والعمل بنشاط وفاعلية عن طريق مجموعه من الحركات البسيطة ولذلك يوصى بالقيام بتمـارين رياضـه الدماغ قبل البدء بعمليـة التعلم لأنها تؤدى لاكتسـاب (Lengel,Kuczala,2010,16);(Flatin,2012,19) (المهارات التي تزيد من سهولة التعلم

وأشـارت دراسـة (2012) Flatin إلى دور رياضـة الدماغ في مرحلة الطفولة المبكرة

هدفت هذه البحث إلى اثر استخدام أنشطة رياضـة الدماغ Brain GYM لتقليل السلوكيات خارج نطاق المهام للطلاب داخل غرفة الصف في مرحلة الطفولة المبكرة خلال وقت الدائرة (وهى التحدث بدلاً من الاندماج في وقت الدائرة واللعب مع الزميل) وكانت أعمار الأطفال ع سنوات ثم تطبيق أنشطة رياضـة الدماغ Brain Gym لمدة ب أسابيع بواقع مرتين باليوم ثم قام بمراقبة الأطفال لمدة r أسابيع دون القيام بأنشطة رياضـة الدماغ، ثم طبق الأنشطة لمدة r أسابيع أخرى، كما أشارت نتائج هذه البحث إلى تأثير تمرينات رياضة الدماغ على تتظيم سلوك الأطفال خارج نطاق المهمة.

وفى هذا الصدد جاءت نتائج دراسة (Wimpy,2011) حيث أظهرت التأثير الايجابي لتدريبات رياضة الدماغ Brain Gym على إدارة سلوك الأطفال وتعزيز التركيز لديهم، حيث كان الهدف منها فحص سلوك الطفل أثناء أداء المهام وقدرته على التحكم الذاتي، والتعرف على تأثير رياضة الدماغ على سلوك الأطفال وكيف أن الارتباط والتكامل بين الجسم والدماغ

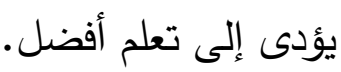

رياضة الدماغ وأثرها على التظيم الذاتي لاى الأطفال ذوى صعوبات التعلم: أن الأطفـال ذوى صـعوبات الـتعلم يعـانون مـن قصـور في التنظيم الـذاتي، وحـل المشكلات فهم يفشلون في معالجة المعلومات فهم اقل في الكفاءة المعرفية، هذا القصور يؤثر سلبياً على النواحي الشخصية والانفعالية والسلوكية. 


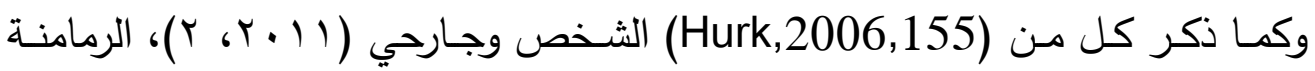

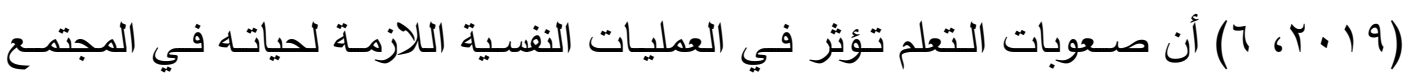
وتشمل الانتباه والذاكرة والإدراك والتي بدورها تؤثر في استعداد الطفل للمهارات الأكاديمية كالقراءة والكتابة والحساب.

والقصور في التنظيم الذاتي لدى صعوبات التعلم يؤثر على رصد وتتفيذ المهام الموكلة إليهه، كما أنهم يعانون من صعوبة في التخلي عن الاستراتيجيات غير الفعالة في عملية التعلم أو استبدالها بإستراتيجية جديدة، مما يجعلهم يحتاجون إلى مهارات التظيم الذاتي، والتي تسـاعد في تعلم واكتساب استراتيجيات جديدة تسهل لهم عملية التعلم، وبالتالي فان تتمية المهارات التظظيم الذاتي تساعد في إصـلاح ذلك القصور مدا يؤثر على النواحي الأكاديمية والاجتماعية.

وقد أوضـحت الدراسـات أن هنـاك صـلة قويـة بـين تحسين التتظيم الذاتي وتحسين المهارات الأكاديميـة بصسورة إيجابيـة مثل دراسـة (2008,234) التعرف على فعالية التظظيم الذاتي في تحسين المهارات الكتابة لدى الأطفال وتحسين قدرتهم على إكمال القصص، وزيادة مفرداتها وجودتها، وزيـادة الزمن المستغرق في النشاط الكتابي، وتكونت عينـة البحث من أطفال الصف الثاني الابتدائي، ممن يعانون من صعوبات تعلم الكتابـة، وتكونـت عينـة البحث مـن أطفـال، وتراوحت أعمـارهم مـا بـين (0- ^) سـوات، وتراوحت معاملات ذكائهم بين (ع 9- r • () وقد استخدم الباحثون مقياس وكسلر للذكاء، واختبار اللغة المكتوبة، ومقياس التقييم السريع للمعرضين لصعوبات تعلم القراءة. (Klassen,2010,27-29);(Butler,2015,123);(Rice\&Carter, وقد أثـار (2016,132. إلى حاجه الأطفال ذوى صسوبات التعلم إلى أسـاليب مناسبة تساعدهم على التحكم بسلوكياتهم ومـن هذه الأسـاليب التنظيم الذاتي هيث أن هؤلاء الأطفال يواجهون 


\section{كلية التربية للطفولة المبكرة- جامعة بني سويف}

تحديات كبيرة في التنظيم الذاتي لذا هم بحاجه إلى السيطرة المعتمدة لبناء أشكال المعرفة، كما أكد (2006) Hurk إلى أهمية التتظيم الذاتي وأثرة على الجوانب الأكاديمية للأطفال وتتضـح أثاره بشكل عام على سلوكيات الأطفال وبشكل خاص على الجوانب الاجتماعية والانفعالية فالأطفال ذوى صعوبات التعلم يفتقرون إلى مهارات التتظيم الذاتي التي تجعلهم يشعرون بالخوف الدائم من الفشل وقلة الدافعية والتي بدورها تؤثر على التحصيل الأكاديمي. والتظظيم الذاتي يعطى الطفل القدرة على التحكم في الأفكار والأهداف الثخصية (Dembo \& Seli, والاستجابة لمطالب البيئة فالتنظيم الذاتي عنصراً أساسياً للنجاح كما أكد $.2013,172)$, (Kirk, 2017, 3)

لذا فقد عمد البحث الحالي إلى استخدام رياضة الدماغ لتدريب التنظيم الذاتي لدى عينة من الأطفال ذوى صعوبات التعلم للتعرف على تأثيره في تحسين التظظيم الذاتي لديهر.

\section{مشكلة البحث}

يعانى الأطفال ذوى صعوبات التعلم من القصور في التظظيم الذاتي الذي يؤثر على رصد وتنفيذ المهام الموكلة إليهم، كما أنهم يعانون من صعوبة في التخلي عن الاستراتيجيات غير الفعالـة في عملية التعلم أو استبدالها بإستراتيجية جديدة، ممـا يجعلهم يحتاجون إلى مهارات التنظيم الذاتي بصورة كبيرة.

وتظهر بعض هذه المشكلات نتيجة قصور التظيم الذاتي لاى الأطفال مما يؤثر على نظـام الفصـل بشكل كبير ويحتـاج المعلمون إلى توفير بيئة تعليميـة مواتيـة للتعلم والنمو والنجاح، كما يعانون من ضـوط وإجهاد بسبب المشكلات السلوكية لذوى صسوبات التعلم التي تتؤدى إلى تشتت الانتباه في الفصل الدراسي، كما يحتاج المعلمون إلى قضـاء أوقات 
إضـافية لتحسين التنظيم الذاتي لدى هؤلاء الأطفال لكي يؤدوا بشكل أفضل سواءً سلوكياً أو أكاديمياً (Hannaford, 2011, 148).

والأطفال في وقتنا هذا يميلون للجلوس على الأجهزة الالكترونية وألعاب الفيديو مما يؤدى إلى زيـادة وزن الأطفال وظهور العديد من المشكلات كما يواجه الأطفال المزيــ من الصعوبات في الفصل الدراسي مع مشكلات الانتباه، وصعوبات التعلم، والتوتر ، أن تطوير المهارات الحركيـة تحفز الاستعداد للتعلم وتزيـــ من تحصيل الأطفـال بشكل سريع وتحسن عملية الإدراك، كما أنها تعمل على تطوير المهارات الاجتماعية والانفعالية، فالأطفال الأكثر نشـاطـا خـلال اليـوم الدراسـي يحقتـون أداء أكـاديمي أفضــل وهـو مــا ذكرتـهـه دراسـة كـل من (Howard, 2007, 17); (Lengel, 2010, 65)

ولقد ركزت معظم الدراسات العربية على البرامج الأكاديمية والعلاج السلوكي للأطفال ذوى صعوبات التعلم، بينما اهتم القليل منها بالتركيز على التتظيم الذاتي، ودوره في خفض أعراض صعوبات التعلم، وذلك على الرغم من أن العديد من الدراسات الأجنبية قد أشارت إلى

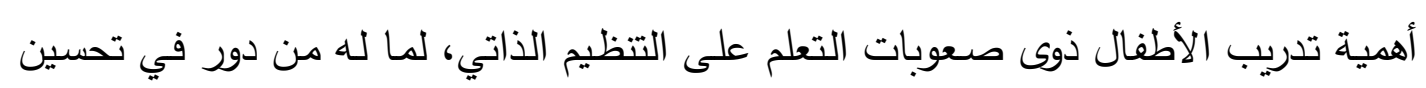
عملية التعلم كدراسة (Graham, 2012) (Viglas, 2018) (Hausand, 2008) حيث أن التدريب على التظظيم الذاتي يسـاعد على التعلم النشط، كما يسهم في بنـاء المعلومـات والمعتقدات ومهارات ما وراء المعرفة، ويضـاف إلى ذلك تركيز الانتباه، وإدراك أكثر ايجابية لفاعلية الذات، كما أن للتظيم الذاتي له أثر في تعلم اللغة وتحسين مهاراتها مثل مهارة الكتابة والقراءة والتعبير عن الأفكار، كما أن الأطفال المنظمون ذاتيا يمتلكون دافعية للتعلم تعكس تقييمهم للتعلم وامتلاكهم للإرادة التي تساعدهم على توجيه الاستراتيجيات المعرفية والسلوكية من خلال التعلم. 


\section{كلية التربية للطفولة المبكرة- جامعة بني سويف}

كما أكدت مجموعة من الدراسات أن الأطفال ذوى صعوبات التعلم يعانون من قصور في التنظيم الذاتي، وحل المشكلات فهم يفشلون في معالجة المعلومات فهم اقل في الكفاءة المعرفيـة، هــا القصــور يـؤثر سـلبيا علـى النــواحي الأكاديميـة والثخصـية والانفعاليـة (Hurk, 2006); (Mantague, 2008); (Lane, et al, 2008); (Reid, 2012); .(Wong, 2012)

وقد أوصـت دراسـة كل من دراسـة كل من (2007,6) و بضرورة دمج الحركة داخل اليوم الدراسي لما لها من أهمية في تحفيز الدماغ وتجهيزه للتعلم وتحفيز وظائف الانتباه حيث يؤثر على التحصيل الدراسي، كما يساعد الأطفال على النجاح في حياتهم في وقت لاحق حيث أن الحركة تسمح للأطفال باستعادة تركيزهم وتقوية قدرتهم على الانتباه، كما أنها تعمل على تعزيز التعلم بشكل كامل، وتعمـل على تحسـين أكثر مـن جانـب مـن جوانـب النمـو مثل النمـو الجســي والمعرفي والانفعالي.

Brain GYM Gو وأظهرت بعض نتائج الدراسـات السـابقة أن استخدام رياضـة الدماغ خاصة في مرحلة الطفولة المبكرة يحسن الأداء الأكاديمي، كما يعمل على خفض السلوكيات السلبية، لا يتوقف على ذلك فقط بل يساعد على إدارة سلوكيات الأطفال وتعزيز التركيز لديهخ وتعزيز الوعي بالذات وزيادة الثقة بالنفس (Miller, 2010, 4) (Flatin, 2012, 2).

ولان تدريب الأطفال على التنظيم الذاتي في مرحلة الطفولة المبكرة يزيد من القدرة على التحكم في الأفكار والأهداف الثخصية والوعي بالذات، فمن الأهمية العمل على تدريبه وتحسينه مبكرا بقدر الإمكان حتى تتحقق النتائج المرجوة، خاصـة بالنسبة للأطفـال ذوى صـعوبات التعلم حيث أنهم بحاجـه إلى تعلم أسـاليب مناسـبة تسـاعدهم على التحكم في سلوكياتهم والتفاعل مع البيئة (Yamada, 2017, 3) (Butler, 2015, 11). 
والأطفال المنظمون ذاتيا يكونون منظمين انفعاليا وسلوكيا، فمثلا يتعلم الأطفال مبكرا

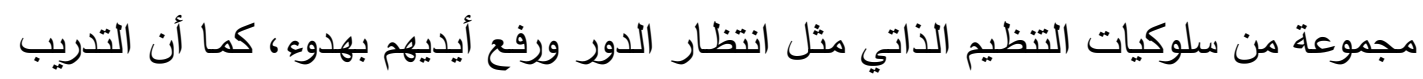
على التنظيم الذاتي في الطفولة المبكرة يجعلهم يصبحون أكثر قدرة على التفكير فيما يفعلونه

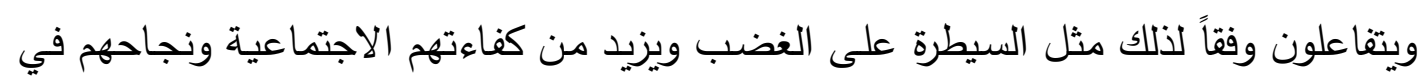
(Lakes, 2004, 283); (Trentacosta, (Zimmerman, 2008, 54); .2009, 89); (Bandy, 2010, 5) أن التظيم الذاتي يعطى الطفل القدرة على التحكم في الأفكار والأهداف الثخصية

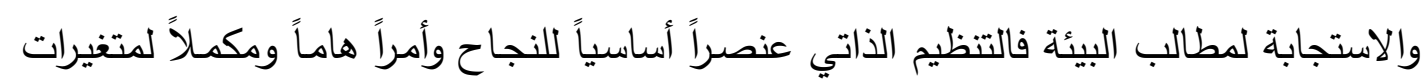

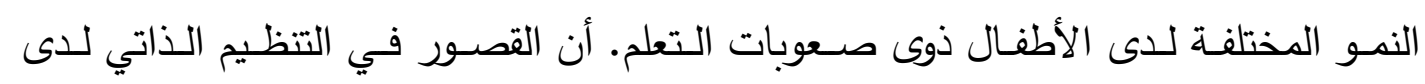
الأطفال ذوى صعوبات التعلم يؤثر على رصد وتتفيذ المهام الموكلة إليهم، كما أنهم يعانون مـن صـعوبة في التخلـي عن الاستراتيجيات غيـر الفعالـة في عمليـة التعلم أو استبدالها

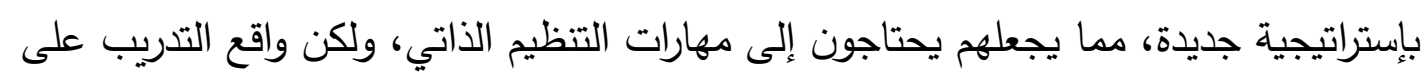

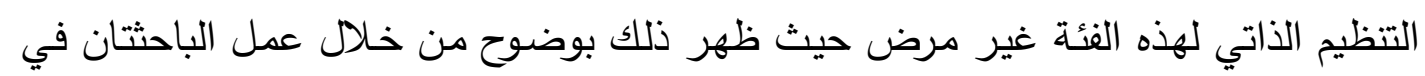

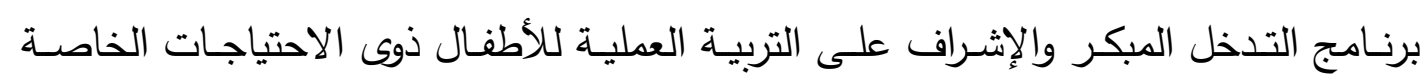
وخاصة صعوبات التعلم مما يمكن وصف هذا الواقع في النقاط التالية:

- أن البرامج التعليمية المقدمة لهؤلاء الأطفال تخلو من عناصر تطوير المهارات وخاصة التي تهتم بالتنظيم الذاتي.

- أن منهاج الصفوف الأساسية الدنيا لا يراعي في محتواه وأهدافه الاهتمام بالتظيم الذاتي لذوي صعوبات التعلم.وعلى ضوه ذلك فقد هدف البحث الحالي تصميم

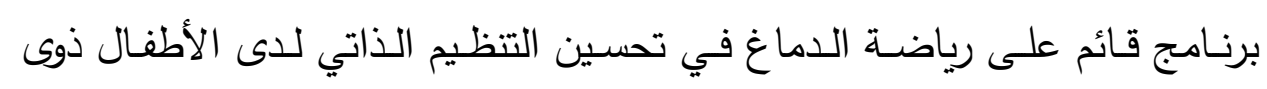

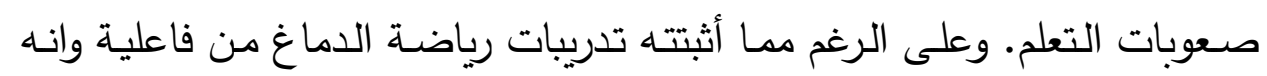
27

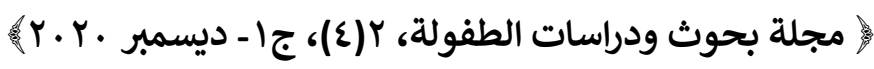




\section{كلية التربية للطفولة المبكرة- جامعة بني سويف}

معروف من أكثر من 9؟عامل، إلا انه لا يوجد سوى القليل من الأدلة التجريبية التي تؤكد أن لبرامج رياضــة الدماغ فوائد وتدعم تطبيقها وهذا مـا ذكره كل من

.(Hyatt, 2007, 43) (Stephenson, 2009, 6)

كما أثـارت دراسة (2011) Wimpy إلى التأثير الأمثل لتدريبات رياضـة الدماغ على السلوك والتواصل الجيد بين الجسم والدماغ والى انه يعد إستراتيجية من استراتيجيات التدخل المبكر لذا يحاول البحث الحالي تقييم فاعلية رياضـة الدماغ على تحسين التظيم الذاتي لدى مجموعة من الأطفال ذوى صعوبات التعلم من خلال برنامج تدريبي قائم على رياضة الدماغ. ومن ثم يمكن بلورة مشكلة البحث الحالية في الأسئلة التالية:

-مـا فاعليـة برنـامج قائم على رياضــة الدماغ في تحسين التظظيم الذاتي لدى الأطفال ذوى

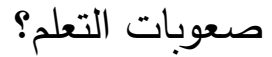

- ما درجه استمرارية فعالية برنامج رياضة الدماغ في تحسين التظيم الذاتي لدى الأطفال ذوى صعوبات التعلم بعد تنفيذه؟

\section{فروض البحث}

وفى ضوء الإطار النظري والدراسات السابقة وما أسفرت عنة من نتائج، وتمت صياغة فروض البحث على النحو الأتي:

1- توجد فروق دالـة إحصـائياً بـين متوسطي رتب درجـات أطفـال المجمـوعتين التجريبيـة والضـابطة في القياس البعدي لأبعاد التنظيم الذاتي ومجموعها الكلى لصـالح أطفـال المجموعة التجريبية. 
ץ- توجد فروق دالة إحصـائياً بين متوسطي رتب درجات أطفال المجموعـة التجريبية في القياسين القبلي والبعدي لأبعاد التنظيم الذاتي ومجموعها الكلى لصالح القياس البعدي. r- لا توجد فروق دالة إحصـائياً بين متوسطي رتب درجات أطفال المجموعة التجريبية في القياسين البعدي والتتبعي لأبعاد التظيم الذاتي ومجموعها الكلى.

\section{أهداف البجثث}

- - هدف البحث الحالي إلى التعرف على فعالية برنامج رياضـة الدماغ Brain GYM في تحسين التنظيم الذاتي لاى الأطفال ذوى صعوبات التعلم.

ويتفرع من هذا الهدف الرئيس الأهداف الفرعية الآتية:

- - التحقق من وجود علاقة بين صعوبات التعلم وضعف التظظيم الذاتي. - - الكثف عن درجة استمرارية فعالية برنامج رياضـة الدماغ في تحسين التظيم الذاتي لدي الأطفال ذوى صعوبات التعلم.

\section{أهمية البحث}

- - يوفر البحث برنامج رياضـة الدماغ Brain GYM "بوصفه يعتمد على الحركة" لإكساب التتظيم الذاتي للأطفال ذوى صعوبات التعلم. - - يوفر البحث أداة لقياس التنظيم الذاتي للأطفال ذوي صعوبات التعلم. - - لفت أنظـار القـائمين على رعايـة الأطفـال ذوى صـوبات التعلم إلى تأثيرات الحركـة الايجابية على سلوك الطفل بصفة عامة، وتأثير رياضة الدماغ بصفة خاصة. 


\section{كلية التربية للطفولة المبكرة- جامعة بني سويف}

- تزويد القائمين على العملية التعليمية من الأخصائيين ومديري المدارس والمعلمين وأولياء الأمور بنتائج علمية حول فعالية رياضة الدماغ وتتمية مهارات الأطفال الأكاديمية.

\section{حلود البحث}

• المحددات المكانيـة: تم انتقاء العينـة من المدرسـة الأوربية بمحافظة الإسكندرية جمهوريـة مصـر العربيـة، وتم تطبيق البرنـامج لتوفير مكان يتم فيـه تدريب الأطفال فيـه وسـهولة التواصل مع الإدارة وتوافر العينة، مما يعين على تطبيق تجربة البحث.

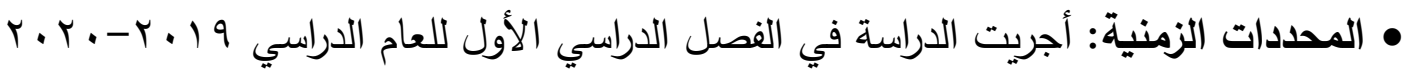

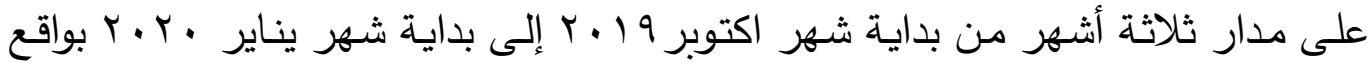
خمس جلسات أسبوعياً، وبذلك يتكون البرنامج التدريبي من ( • ؟) جلسة يتراوح زمن الجلسة

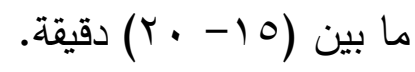

المحددات البشريةة:

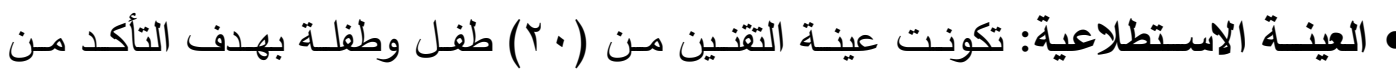
الخصـائص السيكومترية لأدوات البحث من أطفال ذوى صسوبات التعلم بمدرستي جـلال قريطم وهدى شعراوي الرسمية إدارة شرق التعليمية محافظة الإسكندرية، جمهوريـة مصر

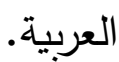

• العينة الأساسية: تكونت العينة الدراسة من (• () أطفال من الأطفال ذوى صعوبات التعلم بالمركز التربوي للطفولـة كلية التربية للطفولـة المبكرة جامعـة الإسكندرية جمهوريـة مصر العربيـة، بمدي عمر زمني (0-0) سنوات بمتوسط عمري (·.9.7) وبـانحراف معياري

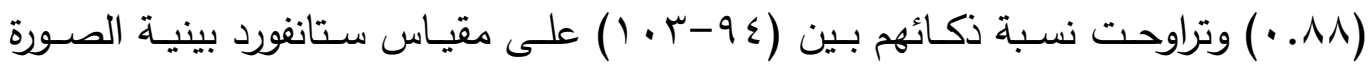

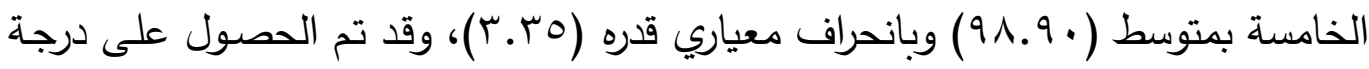


ذكـاء الأطفـال مـن ملفـاتهم الموجـودة بالمدرسـة، وتـم تقسيمهم بالتسـاوي إلى مجمـوعتين تجريبية وضابطة.

\section{منهج البحث}

استخدم المنهج شبه التجريبي تصميم المجموعتين التجريبية والضـابطة(القياس القبلي والبعدي) وذلك لتحديد فاعلية برنامج رياضـة الدماغ في تحسين التنظيم الذاتي لاى الأطفال ذوى صعوبات التعلم

\section{مصطاحسات البحث}

\section{:Brain GYM ر [1 ] [باضة الاماغ}

هي سلسلة منتظمة من الحركات البسيطة والسريعة والممتعة والمشابهة إلى حد بعيد للحركات التي يقوم بها الأطفال في أول ثلاث سنوات من حياتهم والتي تساعد على تهيئة المتعلم للوصول إلى إتقان مهارات التفكير والتنسيق المنظم، والتي تؤدى إلى تتشيط الدماغ وتحسين عملية إعادة الترتيب العصبي (Dennison \& Dennison, 2010). التعريف الإجرائي: هي مجموعة من التدريبات التي تعتمد على الحركة التي تساعد على التكامل بين جانبي الجسم والدماغ مما يعمل على تحفيز الهدوء للأطفال ومسـاعدتهم على التركيز في المواقف الحياتية المختلفة.

[ץ] التظظيم الذاتي Self Regulation

عرفه (2008) Zimmerman (نـه عمليات التوجيه الذاتية والاعتقادات الذاتية التي تساعد على تحويل قدرات الطفل العقلية كالاستعداد اللغوي إلى مهارات أكاديمية، كالكتابة، 
وهو شكل من إثكال النثـاط المتكرر الذي يقوم به الأطفال لاكتساب مهارة أكاديمية مثل وضـع الأهداف واستعراض واختيار الاستراتيجيات والمراقبة الذاتيـة الفعالة على العكس من أنواع النشاطات التي تحدث لأسباب غير شعورية. ويُعرف التتظيم الذاتي إجرائياً بالدرجة التي يحصل عليها الطفل ذوى صعوبات التعلم على مقياس التتظيم الذاتي إعداد الباحثتان.

[ץearning Disabilities صعوبات التعلم

يعرفها (2018) بأنهم هم الأطفال الذين يعانون من خلل في واحدة أو Hallahan

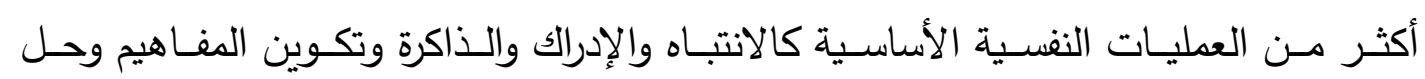
المشكلات وغيرهـا مـن الجوانب المعرفيـة، وترتبط بصـوبات التعلم الأكاديميـة مثل القراءة والكتابة والحساب، ويجب أن لا تكون هذه المشكلات الأكاديمية ناتجة عن إعاقة عقلية أو سمعية أو حركية أو بصرية أو حرمان أو ثقافي أو بيئي أو اقتصادي.

\section{أدوات البحثث}

[ ] مقياس صعوبات التعلم (تعريب وتقنين/ عبد الوهاب كامل 199 1)): أ- الهدف من المقياس:

يهدف هذا المقياس قياس صعوبات التعلم لدى الأطفال وفقًا لقائعـة من الخصـائص السلوكية المنتشرة عادة بين الأطفال ذوى صعوبات التعلم. ب- وصف المقياس:

أعدة مايكل بست Myklebest وعربه وقننه على البيئة المصرية عبد الوهاب كامل (99 (19) يتكون المقياس من ( (Y) فقرة موزعه على خمسة مقاييس فرعية، ويقوم الملاحظ 
(المعلم أو ولي الأمر أو غيرهما) بتحديد درجة كل بند على أحد درجات خمس، والدرجة (r)

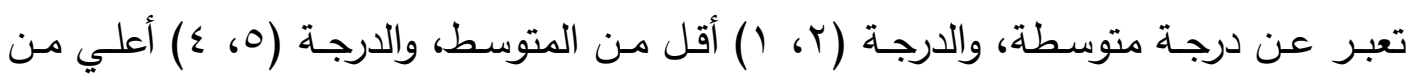
المتوسط، والدرجة العالية تعبر عن عدم وجود صعوبة في التعلم، في حين تشير الدرجة المنخفضة إلى وجود حالة من حالات صعوبات التعلم. ويوضـح الجدول الآتي عدد المفردات المُخصصة لكل مهارة من مهارات صعوبات التعلم في المقياس.

$$
\text { جدول (1) }
$$

عدد المفردات المُخصصة لكل بعد من أبعاد صعوبات التعلم في المقياس

\begin{tabular}{|c|c|c|}
\hline عدد المفردات & \multicolumn{2}{|l|}{ 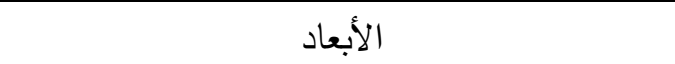 } \\
\hline$\varepsilon$ & الاستيعاب. & \multirow[t]{3}{*}{ الجزء اللفظي } \\
\hline 0 & اللغة. & \\
\hline$\varepsilon$ & المعرفة العامة. & \\
\hline r & التناسق الحركي. & \multirow[t]{2}{*}{ الجزء غير اللفظي } \\
\hline$\wedge$ & السلوك الثخصي والاجتماعي. & \\
\hline$r \varepsilon$ & \multicolumn{2}{|c|}{ المجموع الكلي } \\
\hline
\end{tabular}

ج- صدق المقياس:

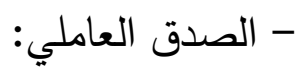
يعتمد الصدق العاملي علي أسلوب التحليل العاملي، وهو أسلوب يكثف مدي تشبع المقياس بالعوامل التي يتكون منها. 


\section{كلية التربية للطفولة المبكرة- جامعة بني سويف}

ولحساب الصدق العاملي لمقياس صعوبات التعلم استخدمت الباحثتان التحليل العاملي

Principal بطريقة المكونات الأساسية Exploratory factor Analysis الاستكثافية Varimx Method مع تدوير المحاور بطريقة الفاريماكس Components Method كما استخدمت الباحثتان اختبار بارتلت Bartlett's Test of Sphericity للتأكد من أن مصفوفة الارتباط لا تساوى مصفوفة الوحدة (Field, A, 2009, 648), وكانت نتيجة اختبار بارتلت Bartlett's Test دالة إحصائياً عند مستوى دلالة ( ( ...)، وهذا يُثير إلى خلو مصفوفة الارتباط من معاملات ارتباط تامة أي أن مصفوفة الارتباط لا تساوى مصفوفة الوحدة وأنه يوجد ارتباط بين بعض المتغيرات في المصفوفة مما يوفر أساسًا سليمًا إحصائًًا لاستخدام أسلوب التحليل العاملي. ويوضح الجدول الآتي نتائج التحليل العاملي الاستكشافي لمقياس صعوبات التعلم.

جدول (r)

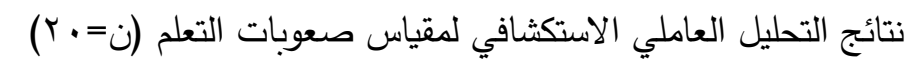

\begin{tabular}{|c|c|c|c|c|c|c|}
\hline \multicolumn{5}{|c|}{ التشبعات } & \multirow[t]{2}{*}{ 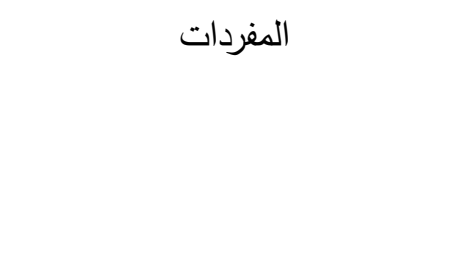 } & \multirow[t]{2}{*}{ ? } \\
\hline الخامس & العامل & الثامل & الثامل & العامل & & \\
\hline & & & & $.0 Y \varepsilon$ & فهم معاني الكلمات. & 1 \\
\hline & & & & $.01 \%$ & إتباع التعليمات. & $r$ \\
\hline & & & & .041 & الدحادثة (فهم المناقشات الصفية). & $\Gamma$ \\
\hline & & & & . . & 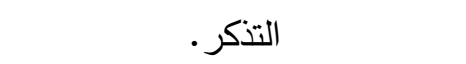 & $\varepsilon$ \\
\hline & & &..$\leqslant 10$ & & 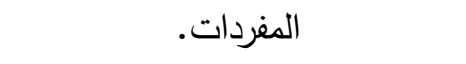 & 0 \\
\hline & & &..$\Sigma \wedge \wedge$ & & القواعد. & 7 \\
\hline
\end{tabular}


كلية التربية للطفولة المبكرة- جامعة بني سويف

\begin{tabular}{|c|c|c|c|c|c|}
\hline & & & $. . \leqslant 9 \leqslant$ & تذكر المفردات. & v \\
\hline & & & $\cdot . \leqslant 79$ & سرد القصص. & $\wedge$ \\
\hline & & & ..$\leqslant T V$ & بناء الأفكار . & 9 \\
\hline & &.$r q$. & & إدراك الوقت. & 1. \\
\hline & & .rvo & & إدراك المكان. & 11 \\
\hline & &.$r \wedge q$ & & إدراك العلاقات (مثل صغير - كبير، قريب- & ir \\
\hline & & .04 & & معرفة الاتجاهات. & $\pi$ \\
\hline & $.0 \leqslant 0$ & & & التتاسق الحركي العام/ مثل (المشي، الركض، & $1 \varepsilon$ \\
\hline & $.0 Y \leqslant$ & & & التوازن. & 10 \\
\hline & $.0 \%$. & & & الدقة في استخدام اليدين في التقاط الأشياء & 17 \\
\hline .0 .9 & & & & التعاون. & iv \\
\hline תTा & & & & الانتباه والتركيز • & 11 \\
\hline$\therefore \leqslant 10$ & & & & التظيم. & 19 \\
\hline$\therefore \leqslant 79$ & & & & التصرفات في المواقف الجديدة (رحلة، حفلة، & $r$. \\
\hline . . « 1 & & & & التقبل الاجتماعي. & r \\
\hline . . थ & & & & المسئولية. & r \\
\hline
\end{tabular}




\section{كلية التربية للطفولة المبكرة- جامعة بني سويف}

\begin{tabular}{|c|c|c|c|c|c|c|}
\hline$\cdot \varepsilon \vee \wedge$ & & & & & إنجاز الواجب. & r \\
\hline$\cdot . \varepsilon \vee 9$ & & & & & الإحساس مع الآخرين (احترام مشاعر الآخرين). & $r \varepsilon$ \\
\hline r.91 & $\varepsilon . \mu$. & $0 . \wedge 7$ & $V . \varepsilon q$ & 9.74 & الجذر الكامن & \\
\hline$V .01$ & $11 . .9$ & 10.14 & 19.r & $r \leqslant . \wedge 0$ & ن التباين & \\
\hline VV.A9 & V. r & 09.19 & $\varepsilon \varepsilon .1 V$ & $r \leqslant . \wedge 0$ & نسبة التباين التجميعي & \\
\hline
\end{tabular}

يتضح من الجدول السابق أن:

العامـل الأول: تثبع عليه عدد (ع) مفردات وبلغت قيمـة جذره الكامن (ب7.9)

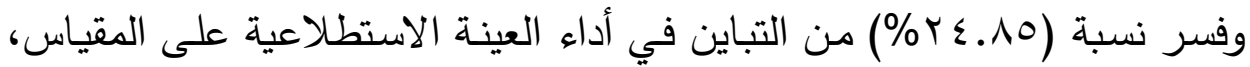
وتشـتمل عباراتـه على فهم معـاني الكلمـات، إتبـاع التعليمـات، المحادثـة (فهـ المناقشات الصفية)، التذكر ، وعليه يُمكن تسميه هذا العامل "بالاستيعاب". العامل الثاني: تشبع عليه عدد (0) مفردات وبلغت قيمـة جذره الكامن (9. (9) وفسر نسبة (ץ.9 (\%)) من التباين في أداء العينة الاستطلاعية على المقياس، وتشتمل عباراتـه على المفردات، القواعد، تذكر المفردات، سرد القصص، بنـاء الأفكار ، وعليه يُمكن تسميه هذا العامل "باللغة". العامل الثالث: تشبع عليه عدد (ع) مفردات وبلغت قيمـة جذره الكامن (7.人.0) وفسر نسبة (r (0 1\%) من التباين في أداء العينة الاستطلاعية على المقياس، وتثتمل عباراته على إدراك الوقت، إدراك المكان، إدراك العلاقات (مثل صغير كبير ، قريب- بعيد)، معرفة الاتجاهات، وعليه يُمكن تسميه هذا العامل "بالمعرفة العامة".

العامل الرابع: تشبع عليه عدد (r) مفردات وبلغت قيمـة جذره الكامن (•r.؟) وفسر نسبة (9 . ـ1\%) من التباين في أداء العينة الاستطلاعية على المقياس، 
وتشـتمل عباراتـه على التناسـق الحركي العـام/ مثل (المشـي، الـركض، القفز، التسلق)، التوازن، الدقة في استخدام اليدين في التقاط الأشياء الدقيقة أو الصغيرة الحجم وعليه يُمكن تسميه هذا العامل "بالتناسق الحركي".

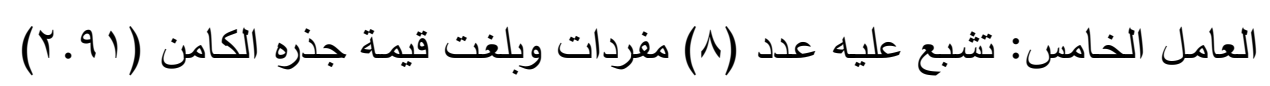

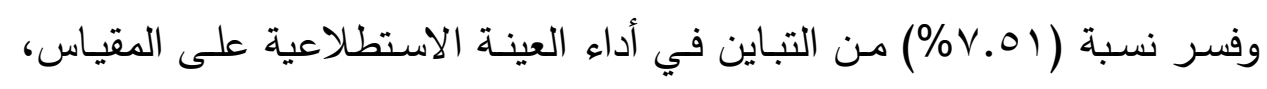
وتدل عباراتـه على التعـاون، الانتباه والتركيز ، التتظيم، التصـرفات في المواقف الجديـدة (رحلـة، حفلـة، تغييـرات في نظـام الحيـاة اليوميـة)، التقبـل الاجتمـاعي، المسئولية، إنجاز الواجب، الإحساس مع الآخرين (احترام مشاعر الآخرين)، وعليه يُمكن تسميه هذا العامل ب- "السلوك الثخصي والاجتماعي". والتشبع المقبول والدال إحصائياً يجب ألا تقل قيمته عن ( • ب. ·)؛ وعليه يتضح من الجدول

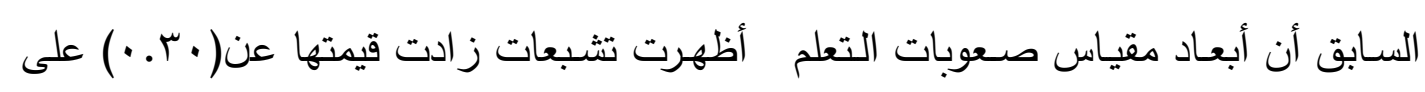
العامل الوحيد ولذلك فهي تشبعات دالة إحصائياً.

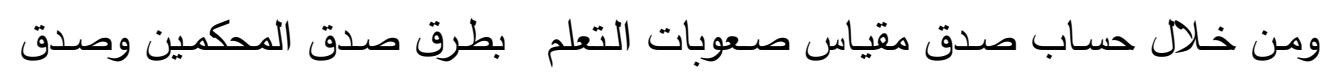
لاوشـي والصدق العاملي يتضـح أن المقياس يتمتع بمعامل صدق مقبول؛ مما يثير إلى لـ إمكانية استخدامه في الدراسة الحالية، والوثوق بالنتائج التي ستسفر عنها الدراسة.

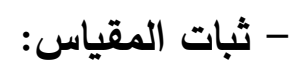

تم حسـاب ثبات المقيـاس بطريقتي ألفـا كرونبـاخ Cronbach's alpha وإعـادة التطبيقTest- Retest وذلك بعد تطبيقه على عينة التقنين المكونـة من ( • (ץ) طفل وطفلة، والنتائج يوضحها الجدول الآتي: 


\section{كلية التربية للطفولة المبكرة- جامعة بني سويف}

جدول (r)

معاملات ثبات مقياس صعوبات التعلم بطريقتي ألفا كرونباخ وإعادة التطبيق (ن=r)

\begin{tabular}{|c|c|c|c|}
\hline \multicolumn{2}{|c|}{ معامل ثبات } & \multicolumn{2}{|l|}{ الأبعاد } \\
\hline إعادة التطبيق & ألفا كرونباخ & & \\
\hline..$\wedge \Sigma 1 * *$ & $\cdot .1 \cdot 9$ & الاستيعاب. & صعوبات \\
\hline •.Aケ.*** & $\cdot . \wedge \cdot \varepsilon$ & اللغة. & التعلم \\
\hline ..А५ & $\cdot . \wedge \cdot \Lambda$ & المعرفة العامة. & \\
\hline •.Атケ*** &..$\wedge 1 \mathrm{r}$ & التناسق الحركي. & \\
\hline •.Ar & $\cdot . \wedge \cdot 1$ & السلوك الشخصي والاجتماعي. & \\
\hline$\cdot . \wedge \wedge . * *$ & . . Arr & المقياس ككل & \\
\hline
\end{tabular}

ومما تقدم ومن خلال حساب ثبات مقياس صعوبات التعلم بطريقتي ألفا كرونباخ وإعادة التطبيق يتضح أن المقياس يتمتع بدرجة مرتفعة من الثبات، مما يشير إلى إمكانية استخدامه في الدراسة الحالية، والوثوق بالنتائج التي ستسفر عنها الدراسة. - تصحيح المقياس: يتم تعبئة نموذج التقييم للمقياس، وذلك بوضع إشارة علي الخاصية التي تصف الطفل في الجانب المطلوب أكثر من غيرها، إذ إن كل فقرة في المقياس تشمل خمس صفات أو خمس بدائل، والمطلوب اختيار بديل واحد مـن هذه البدائل المتدرجة من اعلي الصفة أو الخاصية إلى أدناها، بتحديد درجة كل بند على احد درجات خمس، والدرجة (ب) تعبر عن درجـة متوسطة، والدرجـة (Y، () أقل مـن المتوسط، والدرجـة (0، ع) أعلي مـن المتوسط، والدرجة العالية تعبر عن عدم وجود صعوبة في التعلم، في حين تشير الدرجة المنخفضـة إلى 
وجود حالة من حالات صعوبات التعلم، وتعني الدرجة الكلية التي تقل عن 91. 1 متوسط وجود حالة من صعوبات التعلم.

يتم حساب الدرجة الكلية للمقياس عن طريق جمع الدرجات التي حصل عليها الطفل في المقياس بصورة كلية ثم قسمها علي عدد الفقرات. مجموع الدرجات من الفقرة رقم ( (l)- الفقرة رقم (؟)

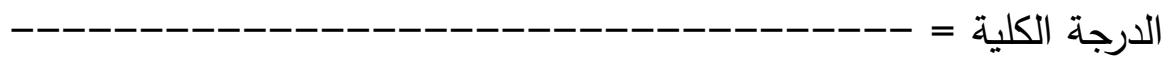

r

[ץ] مقياس التنظيم الذاتي (إعداد/ الباحثتان):

- الهدف من المقياس: يهدف هذا المقياس قياس التتظيم الذاتي لدى الأطفال ذوى صعوبات التعلم.

- وصف المقياس: يتضمن المقياس (• ع) عبارة تم توزيعها على أربعة أبعاد وهى: مراقبة الذات، التخطيط ووضع الأهداف، التتظيم السلوكي، تقويم الذات. ولبناء هذا المقياس اطلعت الباحثتان على العديد من الدراسات والبحوث والمقاييس العربية والأجنبية التي تتاولت موضوع (Zimmerman, 2000; Bandy \& Moore, 2010; التنظيم الذاتي مثل دراسة Klassen, 2010; Graham, \&Berman, 2012; Felver, 2013; Butler \& Schnellert, 2015; Roll, \& Winne, 2015) المُخصصة لأبعاد التنظيم الذاتي في الصورة الأولية للمقياس. 
جدول (飞)

عدد المفردات المُخصصة لأبعاد التنظيم الذاتي في الصورة الأولية للمقياس

\begin{tabular}{|c|c|}
\hline عدد المفردات & الأبعاد \\
\hline 1. & مراقبة الذات. \\
\hline 1. & التخطيط ووضع الأهداف. \\
\hline 1. & التنظيم السلوكي. \\
\hline 1. & تقويم الذات. \\
\hline$\varepsilon$. & المجموع \\
\hline
\end{tabular}

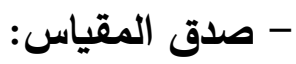

صدق المحكمين وصدق المحتوي للاوشي:

قامـت الباحثتـان بحسـاب صـدق مقيـاس التنظيم الذاتي باسـتخدام صـدق المحكمين

وصدق المحتوي للاوشي Lawshe Content Validity Ratio (CVR) حيث تم عرض المقيـاس في صـورته الأوليـة على عدد ( · () أسـاتذة مـن أسـاتذة الطفولـة المبكرة والتربيـة الخاصـة بالجامعـات المصـرية مصـحوباً بمقدمـة تمهيديـة تضــنت توضـيحاً لمجـال البحث، والهدف منـه، والتعريف الإجرائي لمصطلحاته، بهدف التأكد من صـلاحيته وصدقه لقياس التتظيم الذاتي، وإبداء ملاحظاتهم حول (مدي وضوح وملائمسة صياغة مفردات المقياس مدي وضوح تعليمات المقياس- مدي كفاية مفردات المقياس - مدي وضوح ومناسبة خيارات الإجابة- تعديل أو حذف أو إضافة ما ترونه سيادتكم يحتاج إلى ذلك). كما قامت الباحثتان بحسـاب صدق المحتوي باستخدام معادلة لاوشي Lawshe لحساب نسبة صدق المحتوي Content Validity Ratio (CVR) .(Johnston; Wilkinson, 2009, 5) 
واتضح أن نسب اتفاق السـادة أعضـاء هيئة التدريس بالجامعات علي كل مفردة من مفردات مقيساس التتظيم الذاتي تتراوح مـا بين (•^- . . (\%\%). كمـا اتضـح اتفـاق السـادة

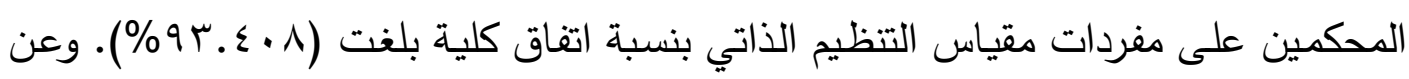
نسبة صدق المحتوى (CVR) للاوشى اتضح أن جميع مفردات مقياس التنظيم الذاتي تتمتع

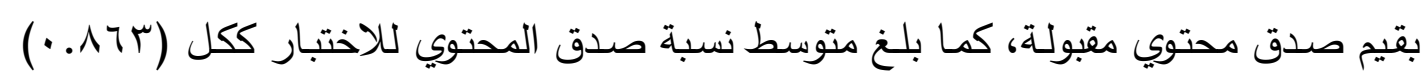

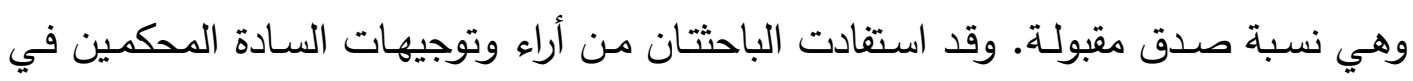

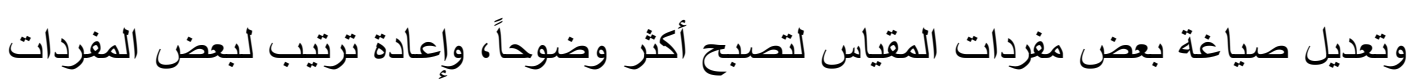
بتقديم بعضها على بعض والعكس صحيح.

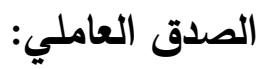
المهمة الأساسية للتحليل العاملي هي تحليل بيانات المتغيرات للتوصل إلى مكونات تتضمنها تلك المتغيرات. حيث يقدم التحليل العاملي نموذج عن التكوين النظري، ويتحدد هذا لهاتئل

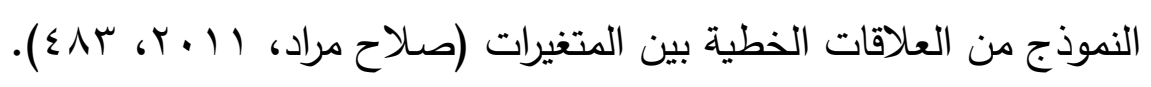

ولحساب الصدق العاملي لدقياس التتظيم الذاتي استخدمت الباحثتان التحليل العاملي

Principal بطريقة المكونات الأساسية Components Method استخدمت الباحثتان اختبار بارتلت Bartlett's Test of Sphericity للتأكد من أن مصفوفة الارتباط لا تساوى مصفوفة الوحدة. (Field, A, 2009, 648), وكانت نتيجة

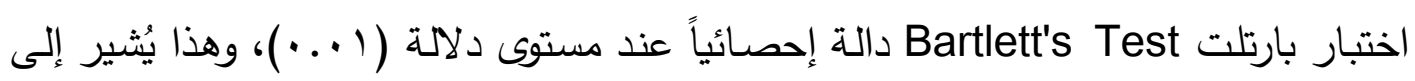

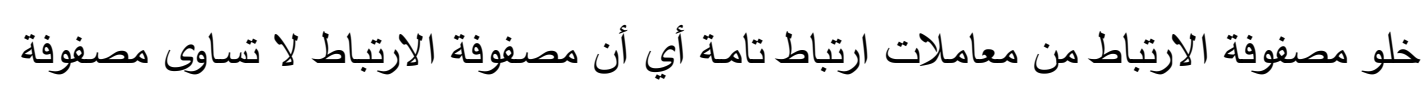
الوحدة وأنه يوجد ارتباط بين بعض المتغيرات في المصفوفة مما يوفر أساسًا سليمًا إحصائيًا 


\section{كلية التربية للطفولة المبكرة- جامعة بني سويف}

لاستخدام أسلوب التحليل العاملي. ويوضح الجدول الآتي نتائج التحليل العاملي الاستكشافي لمقياس التنظيم الذاتي.

جدول (0)

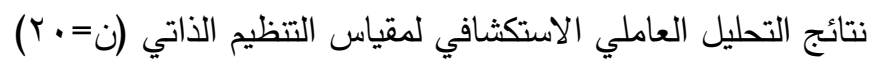

\begin{tabular}{|c|c|c|c|c|c|}
\hline \multicolumn{4}{|c|}{ التثبعات } & \multirow[t]{3}{*}{ 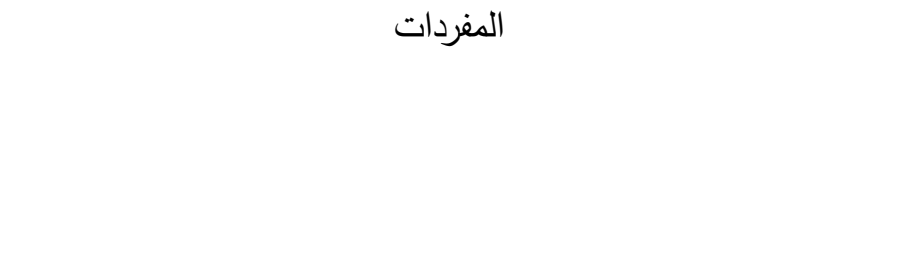 } & \multirow[t]{3}{*}{ s } \\
\hline 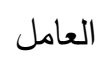 & العامل & 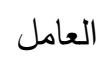 & 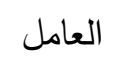 & & \\
\hline 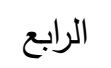 & 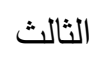 & الثاني & 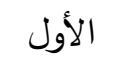 & & \\
\hline & & &..$\leqslant \leqslant$. & انتبه إلى الآثار أفعالي على الفور وليس بعد فوات الأوان & 1 \\
\hline & & & . . & لا ينصرف انتباهي بسهولة عندما أقوم بعمل يجب على فعله & r \\
\hline & & & $.00 r$ & اتبع التعليمات في المنزل والفصل بثكل منتظم & r \\
\hline & & &..$\leqslant \wedge 1$ & انتظر دوري في اللعب والنشاط & $\varepsilon$ \\
\hline & & &. $.00 r$ & اربط بين أدائي لواجبتي ومهامي وما سوف احصل عليه من تعزيز & 0 \\
\hline & & &. $.00 r$ & أفكر في عواقب الثيء قبل أن أقوم بفعله & 7 \\
\hline & & &. $.07 r$ & اطلب المساعدة من المحيطين عندما لا أستطيع فعل شيء ما & V \\
\hline & & & $. .0 \leqslant 1$ & عندما أحاول تغيير شيء ما فأنني انتبه كثيرا كيف افعله & $\wedge$ \\
\hline & & & $\cdot . \leqslant 07$ & انتهى من المهام والواجبات المطلوبة منى حتى إذا تطلبت جهدا كبيرا & 9 \\
\hline & & & $\therefore \leqslant 70$ & لا استغرق وقت كبير للانتقال من نشاط لأخر & 1. \\
\hline & & .094 & & أقوم بتحديد ما يجب على فعله خلال يومي & 11 \\
\hline & & $.00 \leqslant$ & & 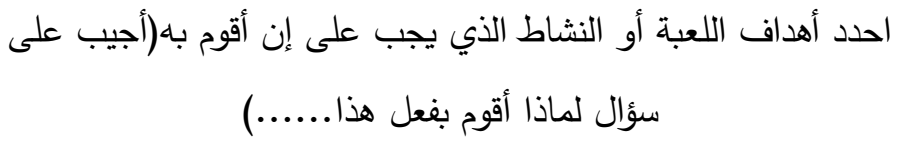 & ir \\
\hline & & $.00 \mathrm{r}$ & & أستطيع تقدير الوقت الذي احتاج إليه للانتهاء من مهامي & Tr \\
\hline
\end{tabular}




\section{كلية التربية للطفولة المبكرة- جامعة بني سويف}

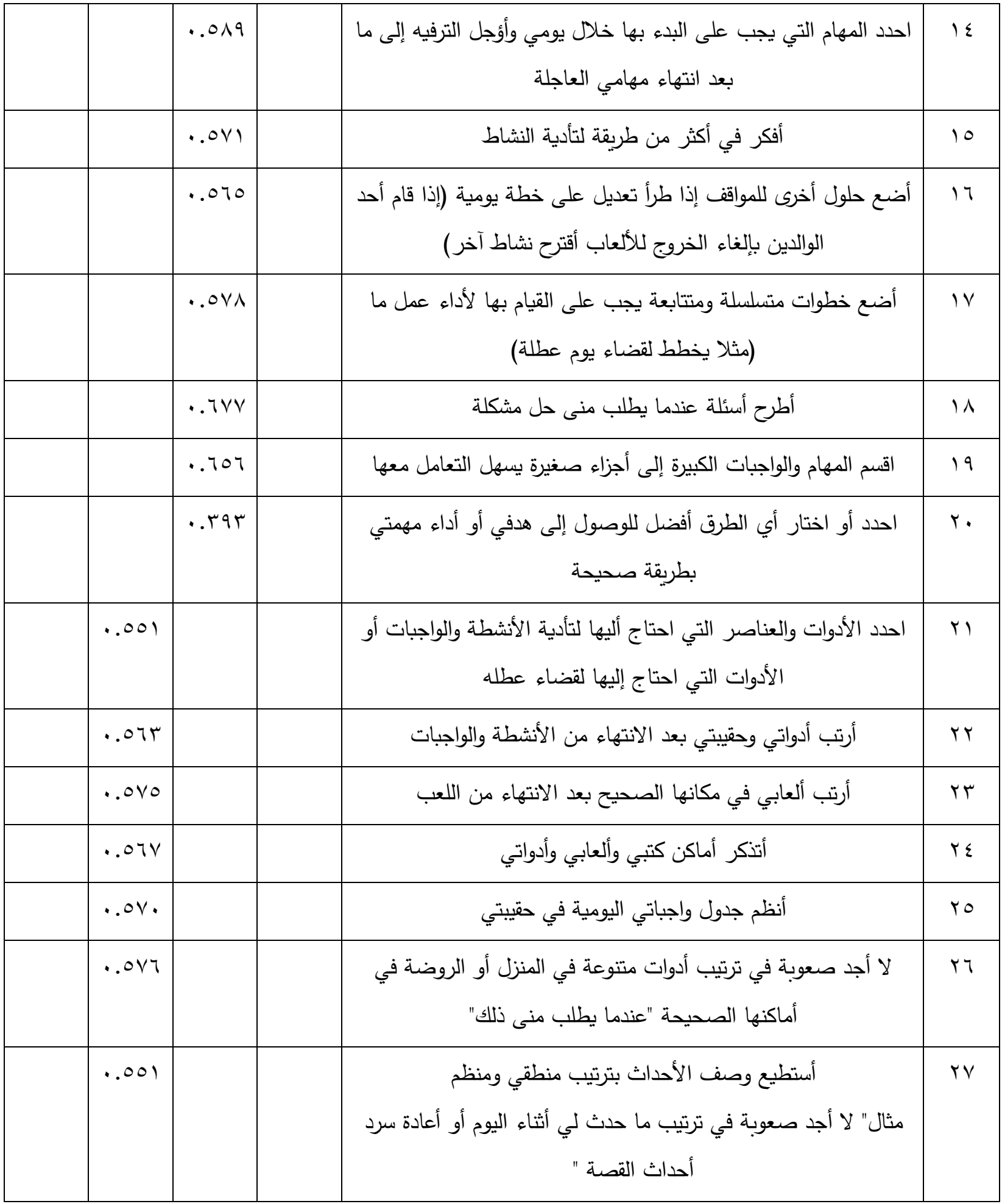




\section{كلية التربية للطفولة المبكرة- جامعة بني سويف}

\begin{tabular}{|c|c|c|c|c|c|}
\hline &. .079 & & & أعرض أفكاري وطلباتي بطريقة منظمة & rᄉ \\
\hline &. $.0 \mathrm{VI}$ & & & 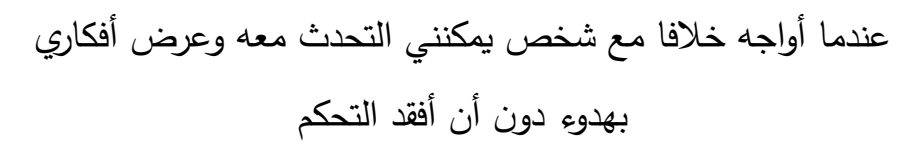 & rq \\
\hline &. .001 & & & أعمل بنظام عندما أعرف أن شيئًاً ما سيكون صعب & r. \\
\hline .010 & & & & أعيد المحاولة إذا أخفقت في تأدية نشاط أو عمل ما " لا استسلم & r \\
\hline .0 .7 & & & & أراجع خطواتي وما قمت به بشكل مستمر & rt \\
\hline$\cdot . \leqslant 77$ & & & & أستطيع التمييز بين المهام السهلة والمهام الصعبة & 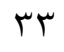 \\
\hline$\cdot . \leqslant 09$ & & & & أقوم بمكافأة نفسي عندما أنجز المهام المطلوبة منى & r纟 \\
\hline$\cdot . \leqslant \varepsilon$. & & & & أعتذر إذا ما قمت بخطأ في حق من حولي & ro \\
\hline$\cdot . \leqslant 7 \leqslant$ & & & & لا أقوم بعمل نفس الخطأ أكثر من مرة " أتعلم من أخطائي " & ד \\
\hline..$\leqslant 07$ & & & & أحدد ما أقوم به صواب أو خطأ من خلال نتائج أفعالي & rv \\
\hline .041 & & & & أقوم بتصحيح أخطائي عندما أعرف بذلك & ґᄉ \\
\hline. .071 & & & & 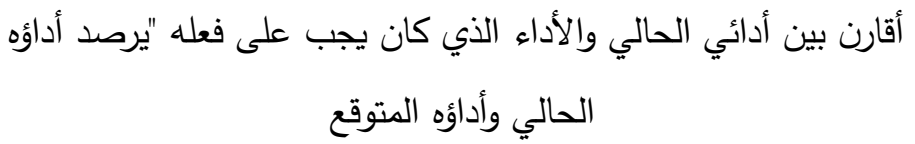 & rq \\
\hline. .011 & & & & أستطيع مقاومه فعل شيء عندما أعلم أنه لا ينبغي على فعل ذلك & $\varepsilon$. \\
\hline $1 . \varepsilon r$ & $r .91$ & $7 . \vee \mu$ & $1 \cdot .9 \leq$ & 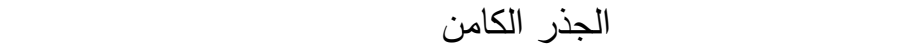 & \\
\hline 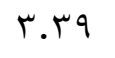 & q.รT & 17 & ro.9 & 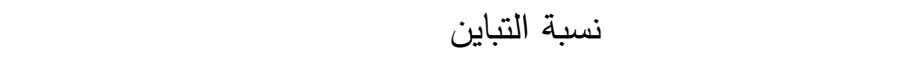 & \\
\hline $0 \leqslant . V$ & 01.1 & $\leqslant 1.9$ & ro.9 & نسبة التباين التجميعي & \\
\hline
\end{tabular}




\section{يتضح من الجدول السابق أن:}

> العامل الأول: تشبع عليه عدد (· () مفردات وبلغت قيمة جذره الكامن (؟9. • () وفسر نسبة (0.9\%\%) مـ التباين في أداء العينـة الاستطلاعية على المقياس، وعليه يُمكن تسميه هذا العامل "بمراقبة الذات".

العامل الثاني: تشبع عليه عدد (• ( ) مفردات وبلغت قيمة جذره الكامن (T.VT) وفسر نسبة (7 (\%) من التباين في أداء العينة الاستطلاعية على المقياس، وعليه يُمكن تسميه هذا العامل "بالتخطيط ووضع الأهداف". العامل الثالث: تثبع عليه عدد ( • () مفردات وبلغت قيمة جذره الكامن (1) (ب) وفسر نسبة (سء. 9\%) من التباين في أداء العينـة الاستطلاعية على المقياس، وعليه يُمكن تسميه هذا العامل "بالتنظيم السلوكي". العامل الرابع: تشبع عليه عدد ( • () مفردات وبلغت قيمة جذره الكامن (بــ ( ) وفسر نسبة (q ب.r\%) من التباين في أداء العينـة الاستطلاعية على المقياس، وعليه يُمكن تسميه هذا العامل "بتقويم الذات". والتشبع المقبول والدال إحصائياً يجب ألا تقل قيمته عن ( • . •)؛ وعليه يتضح من الجدول السابق أن مغردات مقياس التظيم الذاتي أظهرت تشبعات زادت قيمتها عن (•r. •) على العوامل الخمسـة من التحليل العاملي ولذلك فهي تشبعات دالة إحصـائياً. ومن خـلال حساب صدق مقياس التنظيم الذاتي بطرق صدق المحكمين وصدق لاوشي والصدق العاملي يتضح أن المقياس يتمتع بمعامل صدق مقبول؛ مما يشير إلى إمكانية استخدامه في البحث الحالي، والوثوق بالنتائج التي سيسفر عنها البحث. 
تم حساب ثبات المقياس بطريقتي ألفا كرونباخ Cronbach's alpha وإعادة التطبيق Test-Retest يوضحها الجدول الآتي:

جدول (7)

معاملات ثبات مقياس التظظيم الذاتي بطريقتي ألفا كرونباخ وإعادة التطبيق (ن=.ب)

\begin{tabular}{|c|c|c|c|}
\hline \multicolumn{2}{|c|}{ معامل ثبات } & \multicolumn{2}{|l|}{ الأبعاد } \\
\hline إعادة التطبيق & ألفا كرونباخ & & \\
\hline •.^.ケ** & $\therefore \vee \wedge \varepsilon$ & مراقبة الذات. & التنظ \\
\hline.$\wedge r V^{*} *$ &.$V V T$ & التخطيط ووضع الأهداف. & يم \\
\hline.$\wedge$ ^ $q * *$ &.$\vee \vee \vee q$ & التنظيم السلوكي. & الذاتي \\
\hline$\cdot . \wedge 11 * *$ & $\cdot \vee \vee \wedge \wedge$ & تقويم الذات. & \\
\hline$. \wedge \leqslant V^{*} *$ & $\cdot . \wedge \cdot 7$ & المقياس ككل & \\
\hline
\end{tabular}

ومما تقدم ومن خلال حساب ثبات مقياس التنظيم الذاتي بطريقتي ألفا كرونباخ وإعادة التطبيق يتضح أن المقياس يتمتع بدرجة مرتفعة من الثبات، مما يثير إلى إمكانية استخدامه في البحث الحالي، والوثوق بالنتائج التي سيسفر عنها البحث. - تصحيح المقياس: تم تصحيح مقياس التنظيم الذاتي وفقاً لتدريج ليكرت الثلاثي، ويوضـح الجدول الآتي الدرجات المستحقة عند تصحيح مقياس التنظيم الذاتي. 
(v) جدول

الدرجات المستحقة عند تصحيح مقياس التنظيم الذاتي

\begin{tabular}{|c|c|c|c|}
\hline \multicolumn{3}{|c|}{ الإجابة } & \multirow[t]{3}{*}{ المتغيرات } \\
\hline لا ينطبق & ينطبق & ينطبق & \\
\hline عليا إطلاقا & عليا أحياناً & عليا تماماً & \\
\hline 1 & r & r & المفردة الموجبة \\
\hline r & r & 1 & المغردة السالبة \\
\hline \multicolumn{3}{|c|}{ Kr. } & النهائية العظمى للمقياس \\
\hline \multicolumn{3}{|c|}{$\varepsilon$. } & النهائية الصغرى للمقياس \\
\hline
\end{tabular}

[r] [برنامج رياضة الاماغ (إعداد/ الباحثتان):

هو مجموعـة من التدريبات لها طبيعـة حركيه وتتفسيه كما تعتمد أيضـاً علي تدليك مراكز أو نقاط الطاقة بالجسم مـع التأكيد علي شرب الماء، تعمل هذه التدرببات علي تعزيز الجسم مما يعمل علي تدفق الدم للدماغ، وزيادة سرعة السيالات العصبية بين شقي الدماغ لكي يعملا معا بفعالية، مما يؤدي إلى تحسين الأداء. يتكون البرنامج من مجموعة من الجلسات والفنيات المستخدمة لتحقيق أهداف البرنامج مثل التعزيز ، والنمذجة، والمحاكاة والتغذية الراجعة بكافه أشكالها.

\section{ويعتمد برنامج رياضة الدماغ علي مجموعه من النقاط أهمها:}

1- شـرب المـاء بكميـات كافيـة تتناسـب واحتياجـات الجسـم: ويـتم تحديـ كميـة المـاء التي

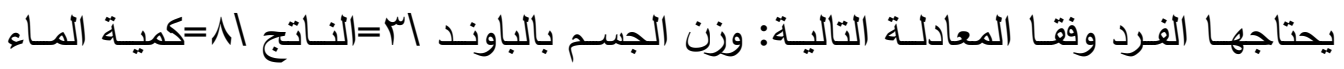

$$
\text { بالأكواب التي يحتاجه الفرد يوميا (الكوب = . . rملل). }
$$




\section{كلية التربية للطفولة المبكرة- جامعة بني سويف}

ץ- التمرينات التنفسية (المشبعة بالأوكسجين): هي عبارة عن تمرينات يتم فيها اخذ شهيق عميق وزفير كامل أثناء أداء التمرينات وهذه التمرينات تسهل عمل التنفس بعمق، وزيـادة كمية الهواء الاخلة الرئتين.

r- نقاط أو مفاتيح الجسم: هي مجموعه من النقاط موزعه في الجسم يتم تدليكها بواسطة الأصابع. كما تعمل هذه النقاط علي تدفق الدم الشبع بالأوكسجين إلي الدماغ. ع - التمرينات العكسية: استخدام تمرينات حركيه للأطراف بشكل متقاطع (تعاكس) أي ذراع يمين وقدم يسار بالعكس.

ه- تمرينات Lazy 8 تحريك الذراعين علي شكل 8المائلة تبدأ من الأعلى إلي الأسفل في الدائرة الأولي ومن الأسفل إلي الأعلى في الدائرة الثانية في التقاطع.

צ- تمرينات Hook- ups: مع وضع الوقوف تشبيك الأصابع وضم الذراعين إلي الصدر.

وقام الباحثتان بتطبيق البرنامج التدريبي وإجراء ما يلزم من تعديلات، تضمنت تقديما أو تأخيرا في ترتيب الجلسـات، وكذلك مـن حيث الأنشطة ودرجـه تعقيدها أو ترتيبها وفقـا لحاجات الأطفال، وبالتالي تمت صياغة تفاصيل الجلسات في صورتها النهائية، وتتقيحها ووضعها في صسوره مناسبة للاستخدام مـع أطفال المجموعـة التجريبية مـن ذوي صـوبات التعلم، وعددهم (• () أطفال، وقد استمر تطبيق البرنـامج علي مدار (Y ( أسبوع، حيث طبقت الجلسات بشكل يومي. وقد تم مراعاة ما يأتي عند تطبيق البرنامج:

1- التدرج من السهل إلي الصعب دائما ومن ثم التقدم مما يحضر العقل والجسد للرغبة في التعلم وهذا يسمح لجميع الأنشطة الجسدية بالمشاركة في عملية التعلم. 


\section{كلية التربية للطفولة المبكرة- جامعة بني سويف}

ץ- تحديد الأهداف مما يعزز من تحديد المشاكل ومن ثم تحليل المواقف فالمراقبة الذاتية

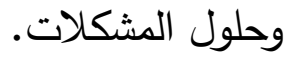

r- حركات التمرينات الموجهة للدماغ التي تتشط جميع النواحي الوظيفية أو البدنية للمتعلم والربط بين الجسم والدماغ، بحيث يشمل محاور الإحساس والقدرات للتجاوب من جميع أجزاء الدماغ.

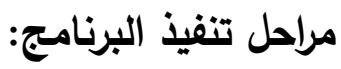
المرحلة التمهيدية: تم خلال هذه المرحلة: • تطبيق المقاييس المستخدمة في الدراسة وهي مقياس التنظيم الذاتي، مقياس مايكل بست للأطفال ذوى صعوبات التعلم، علي مجموعه من الأطفال ذوي صعوبات التعلم. • بـدأ علاقـة تعـارف مـع الأطفـال، وأوليـاء أمـورهم، والأخصـائيين القـائمين علـي رعـايتهح وإعطائهم فكرة عن الهدف البرنـامج، وكيفيـة تنفيذه، ومسـاعدة الطفل علي تعميم المهام والمهارات.

هلال هذه المرحلة يتم تحديد الأوقات في جدول الأطفال المناسبة لتنفيذ التدريبات. المرحلة التنفيذية:

قام الباحثتان بتنفيذ البرنـامج علي مدار ثلاثة أثشهر بواقع خمس جلسـات أسبوعيا،

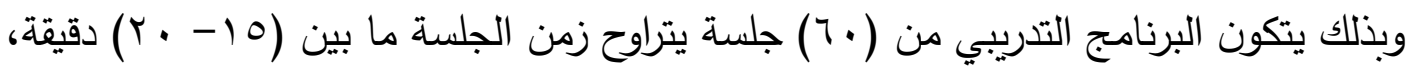
أول خمس دقائق يتم فيها التأكيد علي شرب الماء وتنفيذ التدريب أمام الأطفال كي يستطيعوا التعرف علي الخطوات، وتضمنت كل جلسة تحقيق مجموعة من الأهداف الإجرائية للبرنامج. 


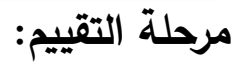

في هذه المرحلة أجرت الباحثتان تقييمـا لفاعلية برنـامج رياضــة الدماغ في تحسين

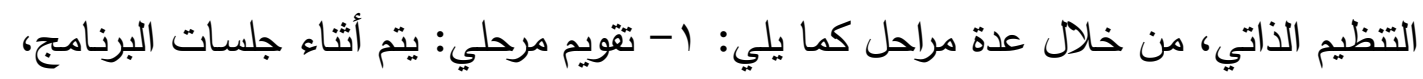

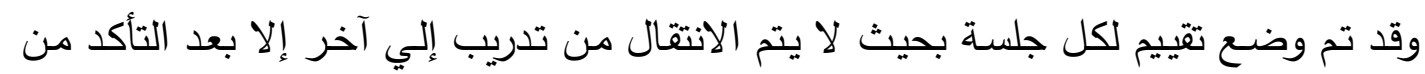
إتقان الطفل للتدريب الحالي.؟- تقويم نهائي: يتم تقييم كل طفل بعد الانتهاء من تطبيق البرنامج مباشرة (تطبيق بعدي).

جدول (^) المخطط العام لجلسات برنامج رياضة الدماغ

\begin{tabular}{|c|c|c|c|c|}
\hline الملاحظات & التمرينات & الوقت & رقم الجلسة & الأسبوع \\
\hline \multirow[t]{3}{*}{ 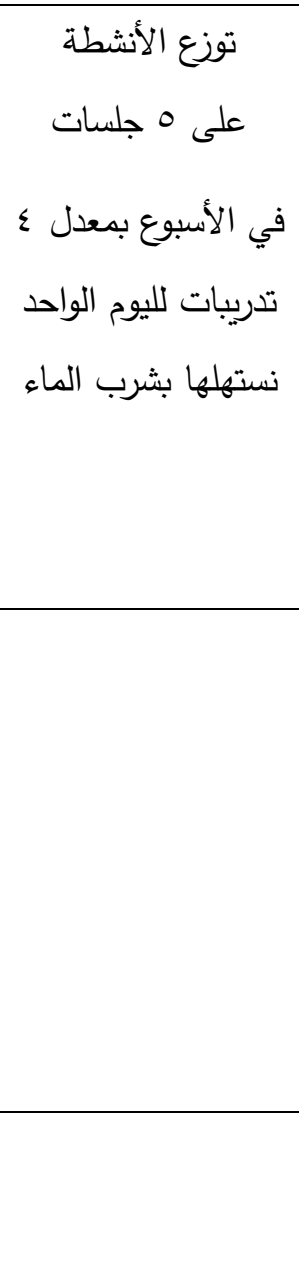 } & 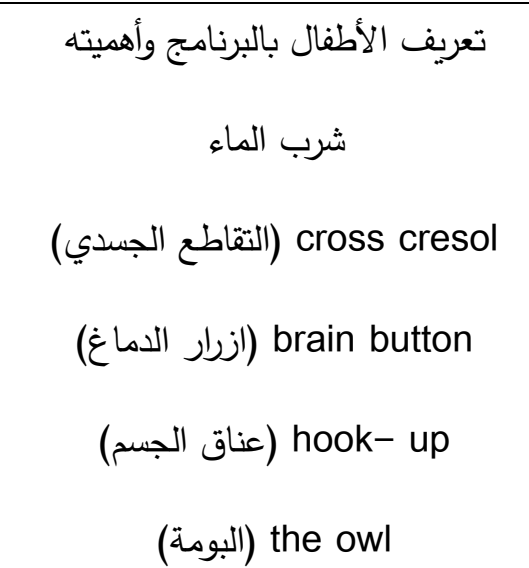 & • لب: 10 & $1: 0$ & الأول \\
\hline & $\begin{array}{c}\text { شرب الماء (تدريب عكسي) Eit up cross } \\
\text { Earth buttons. } \\
\text { (ازرار الأرض) Positive points } \\
\text { (النقاط الإيجابية) The arm activation } \\
\text { (الذراع النشط) }\end{array}$ & • لب: 10 & $7: 1$. & الثاني \\
\hline & شرب الماء & • ب: 10 & $11: 10$ & الثاتث \\
\hline
\end{tabular}

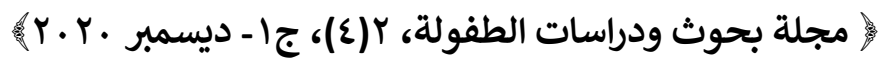


كلية التربية للطفولة المبكرة- جامعة بني سويف

\begin{tabular}{|c|c|c|c|}
\hline 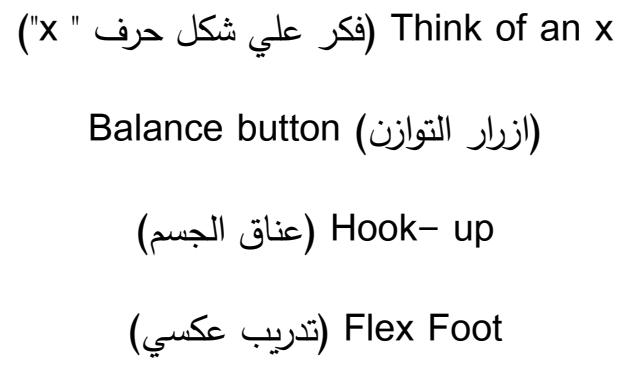 & الواحدة & & \\
\hline $\begin{array}{c}\text { شرب الماء lazy 8's } \\
\text { (الثمانية المائلة) Positive points } \\
\text { (ازرار الفضاء) Calf pump buttons } \\
\text { (ادفع الكتف) الإيجابية) } \\
\text { (النقاء) }\end{array}$ & • ب: 10 & $17: r$. & الرابع \\
\hline 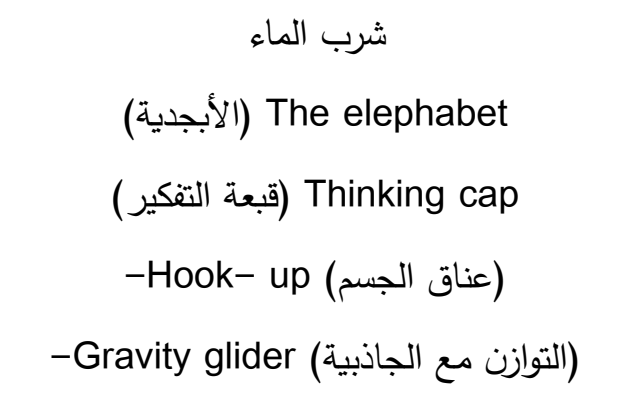 & 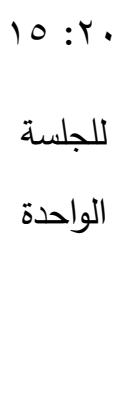 & r) & الخامس \\
\hline $\begin{array}{c}\text { شرب الماء } \text { The elephant } \\
\text { (الفيل) (The grounder }\end{array}$ & • ب: 10 & •r: & السادس \\
\hline $\begin{array}{c}\text { Double doodle } \\
\text { (الخربشة المزدوجة) Brain buttons } \\
\text { (ازرار الدماغ) }\end{array}$ & لب الجل: 10 & هץ: וس & السابع \\
\hline
\end{tabular}




\section{كلية التربية للطفولة المبكرة- جامعة بني سويف}

Positive points

The arm activation

$$
\text { شرب الماء }
$$

$10: r$

ץ

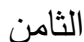

Neck rolls

-Earth buttons (ازرار الأرض)

ook upl

The owl

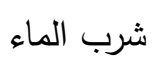

$10: r$.

«1: $\leqslant 0$

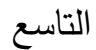

The rocker

Balance button

Positive points

The grounder

$$
\text { شرب الماء }
$$

$10: Y$

$\leqslant \uparrow: 0$.

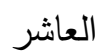

Belly breathing

Space buttons

Hook up

The gravity glider

$$
\text { شرب الماء }
$$

$10: r$

$01: 00$

الحادي

The energizer

The thinking cap

Positive points

Calf pump (ادفع الكتلة)

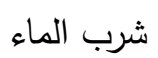

Cross cresol

The energy yawn

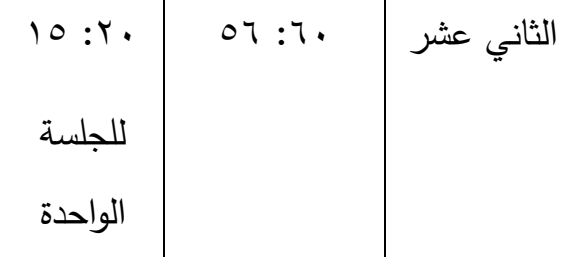




\section{كلية التربية للطفولة المبكرة- جامعة بني سويف}

The nock- up

Positive points

The arm activation

\section{صدق البرنامج القائم على رياضة الاماغ}

تم عرض البرنامج القائم على رياضـة الدماغ في صورته الأولية على عدد ( • () من

أساتذة الطفولة المبكرة والتربية الخاصة بالجامعات المصرية مصحوباً بمقدمة تمهيدية تضمنت توضـيحاً لمجال البحث، والهدف منـه، والتعريف الإجرائي لمصطلحاته، بهدف التأكد من صلاحيته وصدق بنائه وقدرته على تتمية التنظيم الذاتي لدى أطفال الروضـة ذوي صعوبات التعلم، ويوضح الجدول الآتي نسب اتفاق السادة المحكمين على البرنامج القائم على رياضـة الدماغ.

جدول (9)

نسب اتفاق السادة المحكمين على البرنامج القائم على رياضة الدماغ (ن=. ( )

\begin{tabular}{|c|c|c|c|c|}
\hline الاتفاق \% & عرات & عرات & 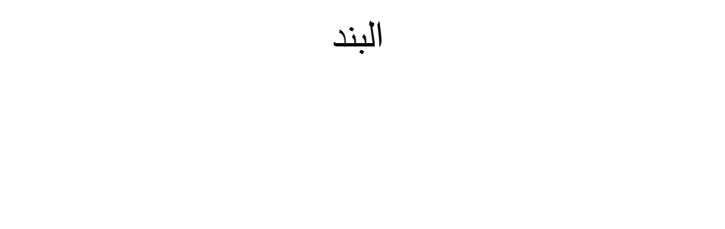 & r \\
\hline $1 \ldots$ & --- & 1. & وضوح أهداف البرنامج. & 1 \\
\hline $9 . .$. & 1 & 9 & الترابط بين أهداف البرنامج ومحتواه. & r \\
\hline $1 \cdots$ & --- & 1. & التسلسل المنطقي لمحتوي البرنامج. & r \\
\hline $9 \ldots$ & 1 & 9 & الترابط بين جلسات البرنامج. & $\varepsilon$ \\
\hline $1 \ldots$ & --- & 1. & كفاية المدة الزمنية المُخططة للبرنامج. & 0 \\
\hline $9 . .$. & 1 & 9 & فعالية الاستراتيجيات التدريسية ومدي ارتباطها بأهداف & 7 \\
\hline
\end{tabular}




\section{كلية التربية للطفولة المبكرة- جامعة بني سويف}

\begin{tabular}{|c|c|c|c|c|}
\hline $1 \ldots$ & --- & 1. & فعالية الوسائل التعليمية المستخدمة ومدي ارتباطها & V \\
\hline$\Lambda \ldots$. & r & $\Lambda$ & فعالية الأنثطة المختلفة ومدي ارتباطها بأهداف & $\wedge$ \\
\hline $9 \ldots$ & 1 & 9 & التكامل بين الأنشطة المختلفة داخل البرنامج. & 9 \\
\hline $1 \ldots$ & --- & 1. & كفاية وملائمة أساليب التقويم المستخدمة في البرنامج. & 1. \\
\hline \multicolumn{3}{|c|}{$\% 9 \leq$} & \multicolumn{2}{|l|}{ النسبة الكلية للاتفاق على البرنامج القائم على رياضـة الدماغ } \\
\hline
\end{tabular}

يتضـح مـن الجدول السـابق أن نسبة الاتفـاق الكليـة مـن قبـل السـادة المحكمـين علي صـالاحية البرنـامج القائم على رياضــة الدماغ بلغت (؟9\%) وهي نسبة اتفاق مرتفعة؛ مدا يُشير إلى صلاحية البرنامج للتطبيق والوثوق بالنتائج التي ستُشفر عنها الدراسة.

\section{خطوات البحث}

قامت الباحثتان باتباع الخطوات الآتية:

ا - دراسة الأبحاث والدراسات المرتبطة بموضوع الدراسة بهدف التعرف علي ما توصلت إليه من نتائج والاستعانة بها في صسياغة فروض الدراسـة الحاليـة واختيار وتصسيم الأدوات وتحديد الأساليب الإحصائية الملائمة للدراسة الحالية.

r- تطبيق مقياس مايكل بست للتعرف على صسوبات التعلم علي الأطفال لانتقاء عينـة البحث.

ع- تطبيق مقياس التظيم الذاتي علي مجموعـه من الأطفال ذوي صعوبات التعلم وتقدير درجاتهم عليه. 


\section{كلية التربية للطفولة المبكرة- جامعة بني سويف}

0- تقسيم العينـة إلى مجموعتين ضـابطه وتجريبية حسب التكافؤ بينهما في العمر الزمني، والذكاء، ومستوى التتظيم الذاتي، وأعراض صعوبات التعلم.

ج- تطبيـق برنـامج رياضــة الـدماغ علـي أطفـال المجموعـة الأطفـال ذوي صـعوبات التتعلم لتحسين التنظيم الذاتي لديهم.

V- تطبيـق الاختبـار البعدي للتنظيم الذاتي للأطفـال ذوي صـعوبات التعلم على أطفـال المجموعـة التجريبية والضـابطة عقب الانتهاء من تطبيق البرنـامج للمقارنة بين درجات الأطفال ذوي صعوبات التعلم.

^- تطبيق الاختبار التتبعي لأطفال المجموعة التجريبية بعد مرور ب شهور من 9- تصحيح الاستجابات وجدولة الدرجات، ومعالجة البيانات إحصائيا بالأساليب الملائمة. • ا - استخلاص النتائج ومناقتتها في ضـوء الإطـار النظري الدراسـات والبحوث المرتبطـة بموضوع الدراسة، وفي ضوء تجربة الدراسة الحالية. 1) - تقديم بعض التوصيات ذات الصلة بموضوع البحث في ضوء مـا أسفرت عنه البحث الحالي

\section{تكافؤ العينة (المجموعتين التجرببية والضابطة)}

التكافؤ في التظيم الذاتي: للتأكد من مدي تحقق التكافؤ بين متوسطي رتب درجات أطفال المجموعتين التجريبية والضـابطة في القياس القبلي لأبعاد التنظيم الذاتي ومجموعها الكلى استخدمت الباحثتان اختبار مان ويتني Mann- Whitney- U Test، والنتائج يوضحها

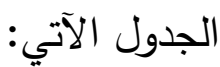




\section{كلية التربية للطفولة المبكرة- جامعة بني سويف}

$$
\text { جدول (·) (1) }
$$

نتائج اختبار "مان ويتي" لدلالة الفروق بين متوسطي رتب درجات أطفال المجموعتين التجريبية والضابطة

$$
\text { في القياس القبلي لأبعاد التتظيم الذاتي ومجموعها الكلى (ن =. (1) }
$$

\begin{tabular}{|c|c|c|c|c|c|c|c|c|c|}
\hline مستوي & "U" & ق" قيمة " Z" & لمجموع & متوسط & الانحراف & الحستوسط & العدد & المجموعة & المتغيرات \\
\hline \multirow{2}{*}{ غير } & \multirow[t]{2}{*}{ V.O } & \multirow[t]{2}{*}{1.111} & TY.O & 7.0 &. .19 & $1 \% .7$. & 0 & التجريبية & \multirow[t]{2}{*}{ مراقبة الذات. } \\
\hline & & & KT.O & $\varepsilon .0$ & 1.21 & IT.A. & 0 & الضابطة & \\
\hline \multirow{2}{*}{ غير } & \multirow[t]{2}{*}{1.} & \multirow[t]{2}{*}{.071} & $r$. & 1 & $1.1 \varepsilon$ & $11 . \varepsilon$. & 0 & التجريبية & \multirow{2}{*}{ التخطيط } \\
\hline & & & ro & 0 &.$v_{1}$ & 11 & 0 & الضابطة & \\
\hline \multirow{2}{*}{ غير } & \multirow[t]{2}{*}{$\wedge$} & \multirow[t]{2}{*}{$1 . .1 \mathrm{~V}$} & r & $\varepsilon .7$ & .00 & IT.E. & 0 & التجريبية & \multirow{2}{*}{ التنظيم. } \\
\hline & & & rr & $7 . \varepsilon$ & $1 . \varepsilon 1$ & $1 \varepsilon$ & 。 & الضابطة & \\
\hline \multirow{2}{*}{ غير } & \multirow[t]{2}{*}{ ᄉ. 0} & \multirow[t]{2}{*}{$\cdot . \wedge V T$} & r. 1.0 & $7 . r$ & $1 . r$. & IT.Y. & 0 & التجريبية & \multirow[t]{2}{*}{ تقويم الذات. } \\
\hline & & & rT.o & $\varepsilon . V$ &. .19 & $11 . \varepsilon$. & 0 & الضابطة & \\
\hline \multirow{2}{*}{ غير } & \multirow[t]{2}{*}{$\wedge$} & \multirow[t]{2}{*}{$\because 9 \leq 9$} & re & $7 . \varepsilon$ & r...V & $0 . .7$. & 0 & التجريبية & \multirow{2}{*}{ لأبعاد التتظيم المجىوع } \\
\hline & & & r & $\varepsilon .7$ & T. $\leqslant q$ & 纟q. . . & 0 & الضابطة & \\
\hline
\end{tabular}

يتضح من الجدول السابق أنه لا توجد فروق دالة إحصائياً عند مستوى دلالة (0...) بين متوسطي رتب درجات أطفال المجموعتين التجريبية والضـابطة في القياس القبلي لأبعاد التتظيم الذاتي (مراقبة الذات- التخطيط ووضـع الأهداف- التتظيم السلوكي - تقويم الذات) ومجموعها الكلي. 


\section{كلية التربية للطفولة المبكرة- جامعة بني سويف}

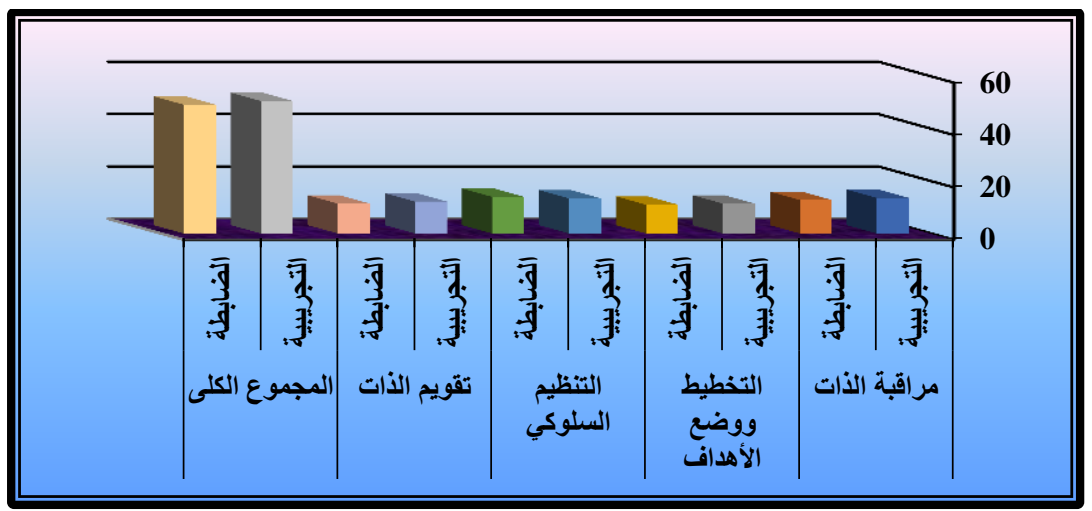

شكل (1)

الأعدة البيانية لمتوسطي درجات أطفال المجموعتين التجريبية والضابطة في القياس القبلي لأبعاد التنظيم الذاتي ومجموعها الكلي

التكافؤ في العمر الزمني: للتأكد من مدي تحقق التكافؤ بين متوسطي رتب درجات أطفال المجموعتين التجريبية والضـابطة في العدر الزمني استخدمت الباحثتان اختبار مـان ويتـي Mann- Whitney- U Test

$$
\text { جدول (1) }
$$

نتائج اختبار "مان ويتتي" لدلالة الفروق بين متوسطي رتب درجات أطفال الهموعتين التجريبية والضابطة

$$
\text { في العمر الزمني (ن =. (1) }
$$

\begin{tabular}{|c|c|c|c|c|c|c|c|c|c|}
\hline مستوي & ق" قيمة & " قيمة " Z" & مجموع الرتب & متوسط & الالحراف & الحسابي & العدد & المجموعة & المتغيرات \\
\hline \multirow{2}{*}{ غير } & \multirow[t]{2}{*}{11} & \multirow[t]{2}{*}{ צrT. } & YT & $0 . r$. & $\cdot . \wedge \varepsilon$ & T.А. & 0 & التجريبية & العمر \\
\hline & & & rq & $0 . \wedge$. & $1 \ldots$ & $v_{\ldots} .$. & 0 & الضابطة & الزمني \\
\hline
\end{tabular}

يتضـح من الجدول السابق أنه لا توجد فروق دالة إحصائياً عند مستوى دلالة (0 . . ) بين متوسطي رتب درجات أطفال المجموعتين التجريبية والضابطة في العمر الزمني. 


\section{كلية التربية للطفولة المبكرة- جامعة بني سويف}

التكافؤ في الذكاء العام: للتأكد من مدي تحقق التكافؤ بين متوسطي رتب درجات أطفال المجموعتين التجريبية والضـابطة في الذكاء العـام استخدمت الباحثتان اختبار مـان ويتتي Mann- Whitney- U Test

$$
\text { جدول (r) (I) (1) }
$$

نتائج اختبار "مان ويتتي" لدلالة الفروق بين متوسطي رتب درجات أطفال المجموعتين التجريبية والضابطة

$$
\text { في الذكاء العام (ن =. (1) }
$$

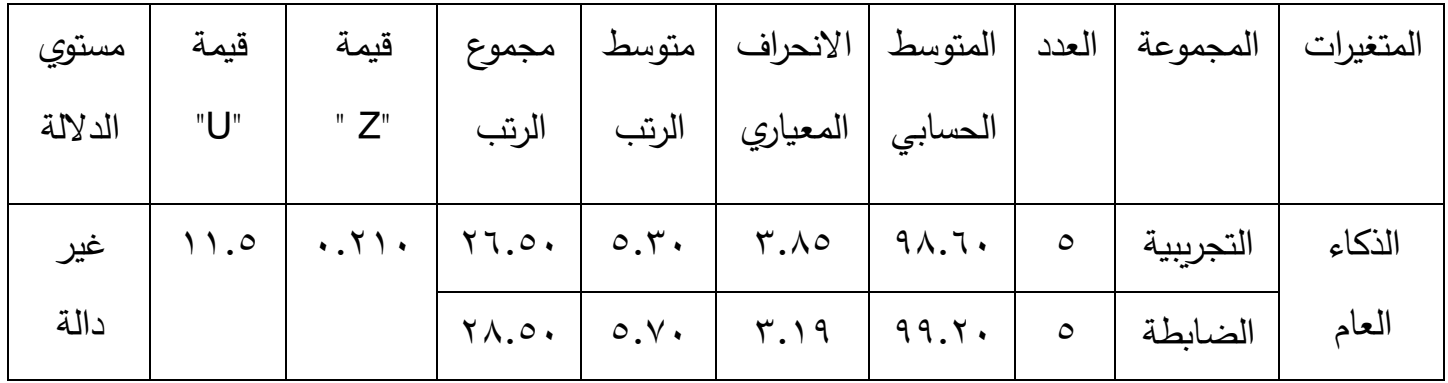

يتضح من الجدول السابق أنه لا توجد فروق دالة إحصـائياً عند مستوى دلالة (0. . ) بين متوسطي رتب درجات أطفال المجموعتين التجريبية والضابطة في الذكاء العام.

ومن خـلال الطرح المتقدم يتضـح التكافؤ بين متوسطي درجات طالبات المجموعتين التجريبية والضابطة في القياس القبلي ل- (العمر الزمني- الذكاء العام- أبعاد التظيم الذاتي ومجموعها الكلي)؛ وعليه يُمكن إرجاع الفروق بين متوسطي درجات طالبات المجموعتين التجريبيـة والضــابطة في القيـاس البعدي لأبعـاد التنظيم الـذاتي ومجموعهـا الكلـي بـين المجموعتين إن وجدت؛ لأثر البرنامج القائم على رياضة الدماغ.

\section{ثمنائج البهث}

يتتـاول هذا الجزء اختبار صـحة فروض البحث وتفسير ومناقشـة النتائج في ضـوء الإطار النظري والدراسات السابقة، وتختتم الباحثتان هذا الجزء بتوصيات الدراسة، والبحوث 


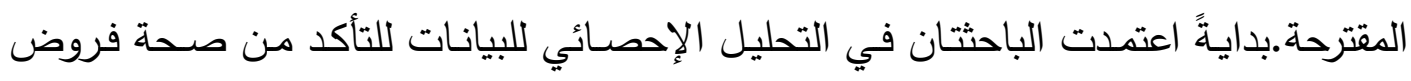
البحث من عدمها على الأساليب الإحصائية الآتية:

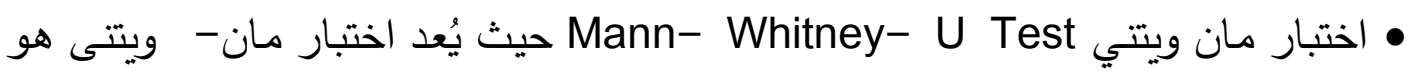

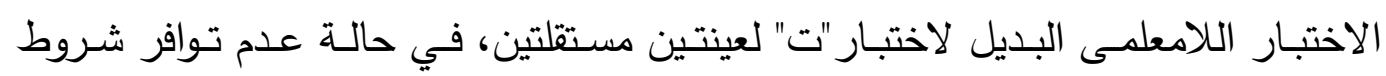

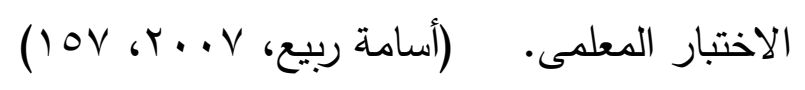

• اختبار ويلكوكسون Wilcoxon حيث يُعد اختبار "ويلكوكسن" لعينتين غير مستقلتين بديلا

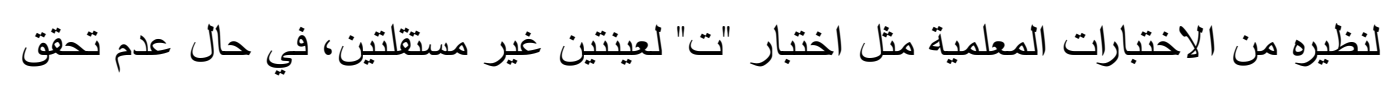

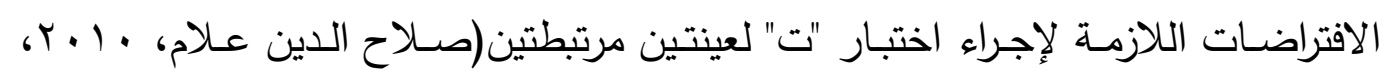
(ro人

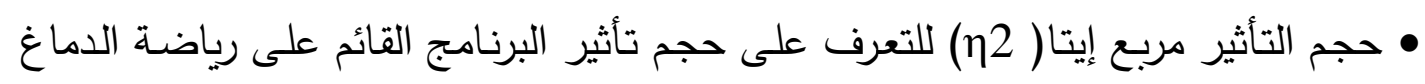

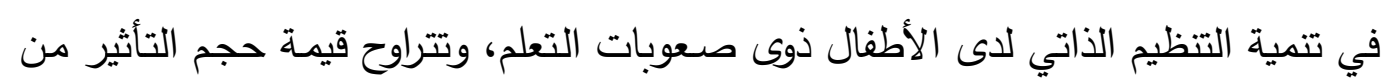

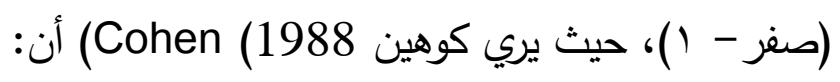

$$
\text { - تعني القيمة ( (. - ) حجم تأثير منخفض. }
$$

- تعني القيمة (0. ·) حجم تأثير مرتفع (Foreman, D., 2009, 59). وقد استخدمت الباحثتان في التحليل الإحصـائي للبيانات حزمـة البرامج الإحصـائية للعلوم الاجتماعية (SPS20) وذلك لإجراء المعالجات الإحصائية، كما يلي:

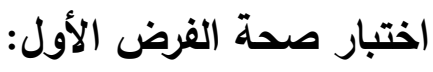

ينص على أنـه "توجد فـروق دالــ إحصـائياً بـين متوسطي رتب درجـات أطفـال

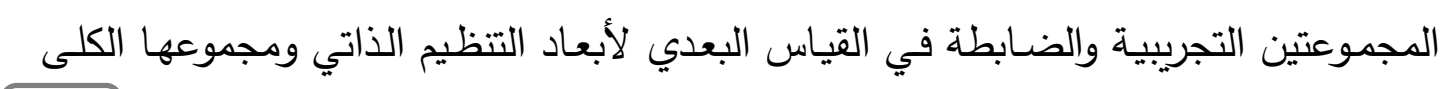
59

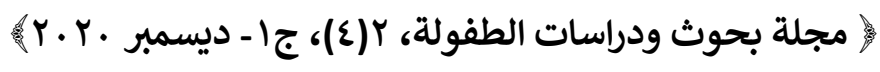




\section{كلية التربية للطفولة المبكرة- جامعة بني سويف}

لصالح أطفال المجموعة التجريبية". ولاختبار صحة هذا الفرض استخدمت الباحثتان اختبار مان ويتني Mann- Whitney- U Test لحساب دلالة الفروق بين متوسطي رتب درجات أطفال المجموعتين التجربيية والضـابطة في القياس البعدي لأبعاد التتظيم الذاتي ومجموعها الكلى، كما قامت الباحثتان بحساب حجم التأثير مربع إيتا (2) للتعرف على حجم تأثير البرنامج القائم على رياضـة الدماغ في تتمية التظظيم الذاتي لدى أطفال المجموعة التجريبية بالمقارنة بأطفال المجموعة الضابطة، والنتائج يوضحها الجدول الآتي:

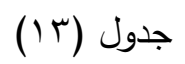

نتائج اختبار "مان ويتتي" وقيمة حجم التأثير لدلالة الفروق بين متوسطي رتب درجات أطفال المجوعتين التجريبية والضابطة في القياس البعدي لأبعاد التظظيم الذاتي ومجموعها الكلى (ن =. ( )

\begin{tabular}{|c|c|c|c|c|c|c|c|c|c|c|c|}
\hline \multicolumn{2}{|c|}{ حجم التأثير (†2) } & \multirow{2}{*}{ مستوي } & \multirow{2}{*}{ قيمة } & \multirow{2}{*}{$\begin{array}{l}\text { قيمة } \\
\text { " Z" }\end{array}$} & \multirow{2}{*}{ مجموع } & \multirow{2}{*}{ متوسط } & \multirow{2}{*}{ الانحراف } & \multirow{2}{*}{ الحسابي } & \multirow[t]{2}{*}{ العدد } & \multirow[t]{2}{*}{ المجموعة } & \multirow[t]{2}{*}{ المتغيرات } \\
\hline الدلالة & القيمة & & & & & & & & & & \\
\hline \multirow[t]{2}{*}{ مرتفع } & \multirow[t]{2}{*}{$. . \wedge \leqslant V$} & \multirow[t]{2}{*}{$\cdots+1$} & \multirow[t]{2}{*}{ صفر } & \multirow[t]{2}{*}{ Y.TVV } & $\varepsilon$. & $\wedge$ &..$v 1$ & TV & 0 & التجريبية & \multirow[t]{2}{*}{ مراقبة الذات. } \\
\hline & & & & & 10 & $r$ & $1 . \varepsilon 1$ & $1 \varepsilon$ & 0 & الضابطة & \\
\hline \multirow[t]{2}{*}{ مرتفع } & \multirow[t]{2}{*}{. .AT } & \multirow[t]{2}{*}{$\cdots+1$} & \multirow[t]{2}{*}{ صفر } & \multirow[t]{2}{*}{ r.TYV } & $\varepsilon$. & $\wedge$ & $1 . \leqslant 1$ & $r \leqslant . \wedge$. & 0 & التجريبية & \multirow{2}{*}{ الألخطيط } \\
\hline & & & & & 10 & $r$ & $1.1 \varepsilon$ & IT.E. & 0 & الضابطة & \\
\hline \multirow[t]{2}{*}{ مرتفع } & \multirow[t]{2}{*}{ 槒. } & \multirow[t]{2}{*}{$\cdots+1$} & \multirow[t]{2}{*}{ صفر } & \multirow[t]{2}{*}{ r.tro } & $\varepsilon$. & $\wedge$ &.$\wedge \varepsilon$ & YV.A. & 0 & التجريبية & \multirow{2}{*}{ السلوكي. } \\
\hline & & & & & 10 & $r$ & r.00 & 10 & 0 & الضابطة & \\
\hline \multirow[t]{2}{*}{ مرتفع } & \multirow[t]{2}{*}{..$\Delta T$} & \multirow[t]{2}{*}{$\cdots+1$} & \multirow[t]{2}{*}{ صفر } & \multirow[t]{2}{*}{ Y.TYV } & $\varepsilon$. & $\wedge$ & $1 . \wedge r$ & r.. . & 0 & التجريبية & \multirow[t]{2}{*}{ تقويم الذات. } \\
\hline & & & & & 10 & $r$ & $1 . \varepsilon \wedge$ & IT.r. & 0 & الضابطة & \\
\hline \multirow[t]{2}{*}{ مرتفع } & \multirow[t]{2}{*}{.$\wedge r q$} & $\ldots 1$ & صفز & r.70Y & $\varepsilon$. & $\wedge$ & $1 . r$. & $1.1 . r$. & 0 & التجريبية & لمجموع الكلى \\
\hline & & & & & 10 & $r$ & r.9V & or.t. & 0 & الضابطة & لأبعاد التتظيم \\
\hline
\end{tabular}




\section{كلية التربية للطفولة المبكرة- جامعة بني سويف}

يتضـح من الجدول السابق أنه توجد فروق دالة إحصـائياً عند مستوى دلالة ( ( .. ) بين متوسطي رتب درجات أطفال المجموعتين التجريبية والضـابطة في القياس البعدي لأبعاد التنظيم الذاتي(مراقبة الذات- التخطيط ووضـع الأهداف- التنظيم السلوكي - تقويم الذات) ومجموعها الكلي لصالح أطفال المجموعة التجريبية.

كما يتضـح من الجدول السـابق أن قيم حجم تأثير (12) البرنـامج القائم على رياضـة الدماغ في تتميـة أبعـاد التتظيم الذاتي ومجموعها الكلي لدى أطفال المجموعـة التجريبيـة

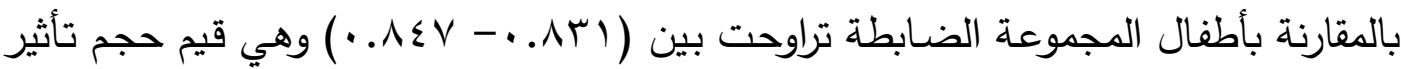

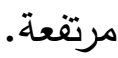

ويوضح الثكل الآتي الأعمدة البيانية لمتوسطي درجات أطفال المجموعتين التجريبية والضابطة في القياس البعدي لأبعاد التنظيم الذاتي ومجموعها الكلي.

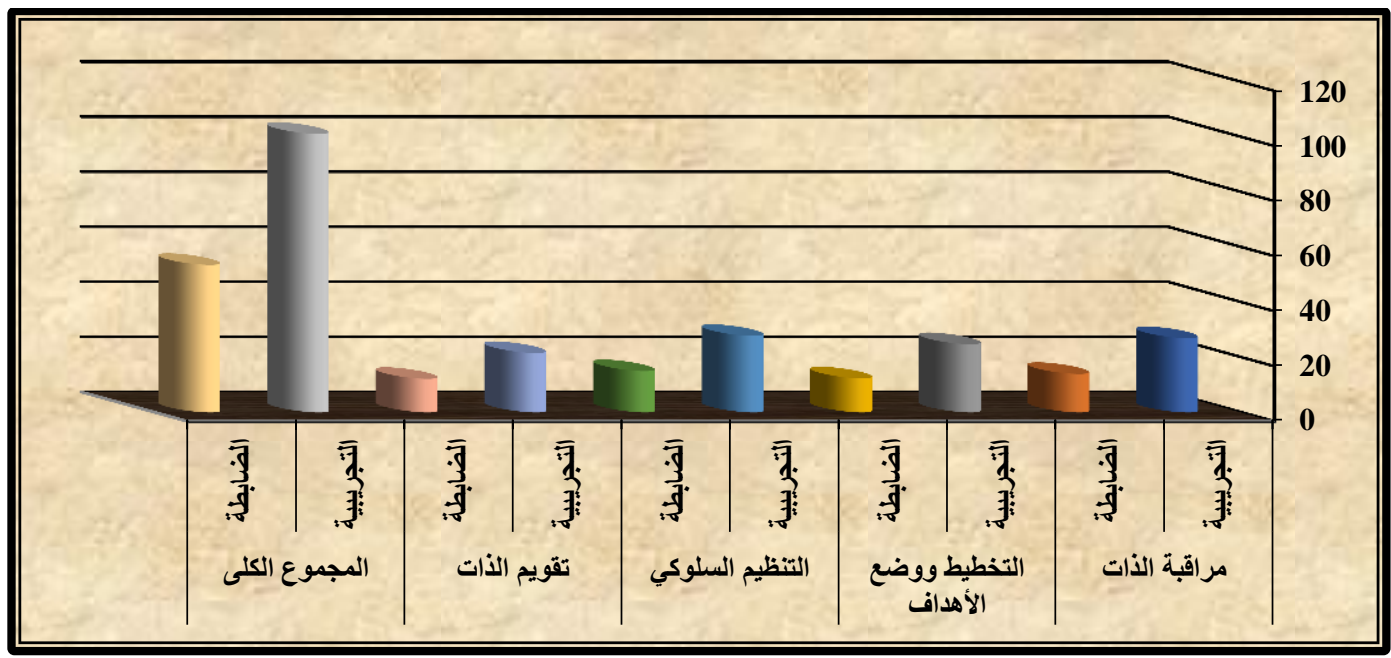

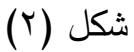

الأعمدة البيانية لمتوسطي درجات أطفال المجموعتين التجريبية والضابطة في القياس البعدي لأبعاد التنظيم الذاتي ومجموعها الكلي 


\section{كلية التربية للطفولة المبكرة- جامعة بني سويف}

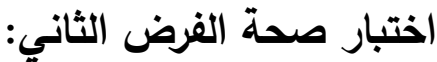

ينص على أنه "توجد فروق دالة إحصائياً بين متوسطي رتب درجات أطفال المجموعة التجريبية في القياسين القبلي والبعدي لأبعاد التظيم الذاتي ومجموعها الكلى لصالح القياس Wilcoxon ( البعدي". ولاختبار صحة هذا الفرض استخدمت الباحثتان اختبار "ويلكوكسون (Signed Ranks Test لحساب دلالة الفروق بين متوسطي رتب درجات أطفال المجموعة التجريبية في القياسين القبلي والبعدي لأبعاد التنظيم الذاتي ومجموعها الكلى، كمـا قامـ الباحثتان بحساب حجم التأثير مربع إيتا (†2) للتعرف على حجم تأثير البرنامج القائم على رياضـة الدماغ في تتميـة التنظيم الذاتي لدى أطفال المجموعـة التجريبية، والنتائج يوضـحها

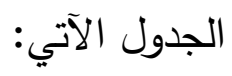

$$
\text { جدول (乏) }
$$

نتائج اختبار ويلكوكسون وقيمة (Z) وقيمة حجم التأثير لدلالة الفروق بين متوسطي رتب درجات أطفال

\begin{tabular}{|c|c|c|c|c|c|c|c|c|c|c|c|}
\hline \multicolumn{2}{|c|}{ 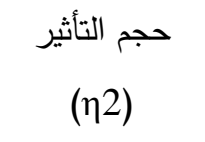 } & \multirow[t]{2}{*}{ مستوى } & \multirow[t]{2}{*}{ " قيمة } & \multirow[t]{2}{*}{ مجموع } & \multirow[t]{2}{*}{ متوسطات } & \multirow[t]{2}{*}{ العدد } & \multirow[t]{2}{*}{ توزيع الرتب } & \multirow[t]{2}{*}{ |الانحراف } & \multirow[t]{2}{*}{ الحسابي } & \multirow[t]{2}{*}{ القياس } & \multirow[t]{2}{*}{ المتغير } \\
\hline الدلالة & القيمة & & & & & & & & & & \\
\hline \multirow[t]{3}{*}{ مرتفع } & \multirow[t]{3}{*}{$.7 \leqslant T$} & \multirow[t]{3}{*}{$\ldots 0$} & \multirow[t]{3}{*}{ r..Pr } & \multirow{3}{*}{$\begin{array}{l}\cdot \\
10\end{array}$} & \multirow{3}{*}{ • } & . & الرتب السالبة & \multirow{3}{*}{$\begin{array}{l}. .19 \\
. .21\end{array}$} & \multirow{3}{*}{$T_{T V}^{T H . T .}$} & \multirow{3}{*}{ البعدي } & \multirow{3}{*}{ مراقبة } \\
\hline & & & & & & 0 & الرتب الموجبة & & & & \\
\hline & & & & & & . & الرتب المتعادلة & & & & \\
\hline \multirow[t]{3}{*}{ مرتفع } & \multirow[t]{3}{*}{$.7 \leqslant r$} & \multirow[t]{3}{*}{$\ldots 0$} & \multirow[t]{3}{*}{ r..rT } & \multirow{3}{*}{10} & \multirow{3}{*}{$r$} & . & الرتب السالبة & \multirow{3}{*}{$\begin{array}{l}1.1 \leqslant \\
1 . \leqslant 1\end{array}$} & \multirow{3}{*}{$\begin{array}{l}11 . \leq . \\
r \leq . \wedge .\end{array}$} & \multirow{3}{*}{ البعبي } & \multirow{3}{*}{ الألخدطيط } \\
\hline & & & & & & 0 & الرتب الموجبة & & & & \\
\hline & & & & & & · & الرتب المتعادلة & & & & \\
\hline مرتفع & $. T \leqslant T$ & $\ldots .0$ & $r . . r r$ & . & · & . & الرتب السالبة & .00 & $1 T . \varepsilon$. & القبلي & التنظيم \\
\hline
\end{tabular}
المجموعة التجريبية في القياسين القبلي والبعدي لأبعاد التنظيم الذاتي ومجموعها الكلى (ن=ه) 


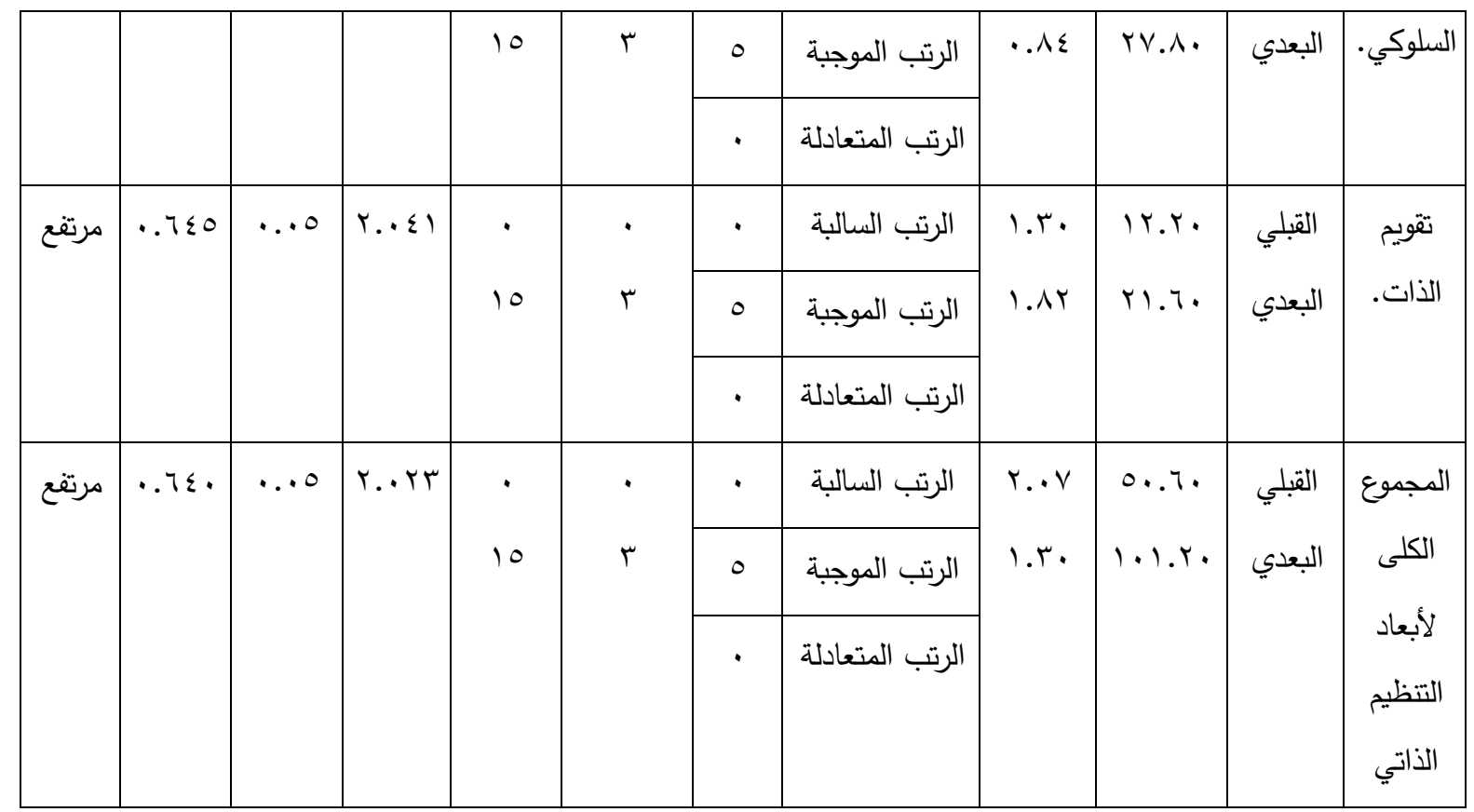

يتضـح من الجدول السـابق أنه توجد فروق دالة إحصـائياً عند مستوى دلالة (0. . ) بين متوسطي رتب درجات أطفال المجموعة التجريبية في القياسين القبلي والبعدي لأبعاد التنظيم الذاتي (مراقبة الذات- التخطيط ووضـع الأهداف- التتظيم السلوكي- تقويم الذات) ومجموعها الكلى لصالح القياس البعدي. كما يتضـح من الجدول السـابق أن قيم حجم تأثير (12) البرنامج القائم على رياضـة الـماغ في تنميـة أبعـاد التنظيم الذاتي ومجموعها الكلي لدى أطفـال المجموعـة التجريبيـة

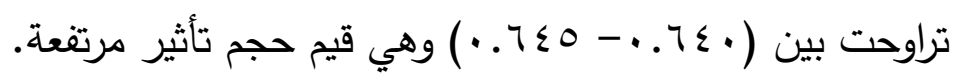
ويوضح الثكل الآتي الأعمدة البيانية لمتوسطي درجات أطفال المجموعة التجريبية في القياسين القبلي والبعدي لأبعاد التنظيم الذاتي ومجموعها الكلى. 


\section{كلية التربية للطفولة المبكرة- جامعة بني سويف}

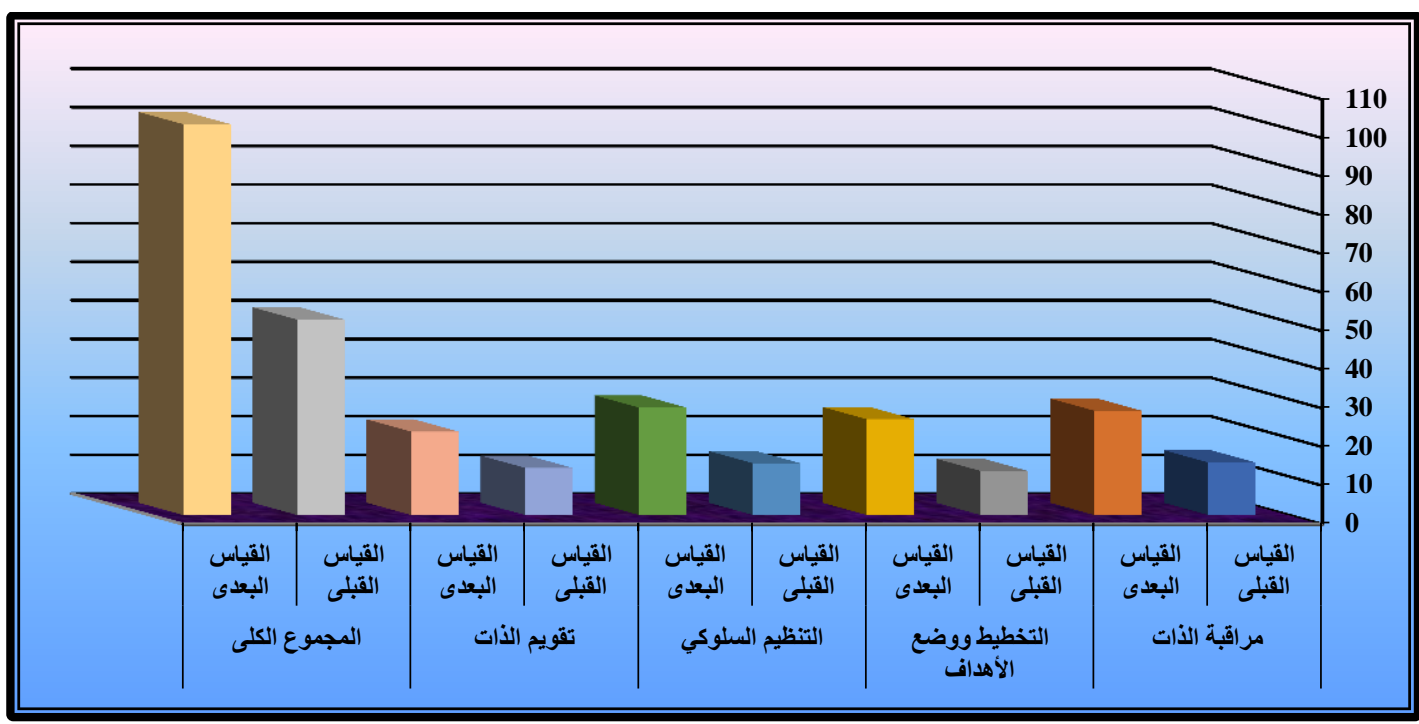

شكل (r)

الأعمدة البيانية لمتوسطي درجات أطفال المجموعة التجريبية في القياسين القبلي والبعدي لأبعاد التنظيم

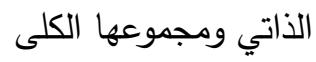

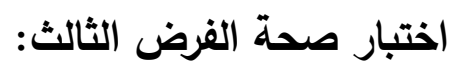

يـص على أنـه " لا توجد فروق دالـة إحصـائياً بـين متوسطي رتب درجـات أطفـال

المجموعة التجريبية في القياسين البعدي والتتبعي لأبعاد التنظيم الذاتي ومجموعها الكلى" . ولاختبار صحة هذا الفرض استخدمت الباحثتان اختبار "ويلكوكسون" ( Wilcoxon Signed (Ranks Test في القياسـين البعدي والتتبعي لأبعـاد التنظيم الذاتي ومجموعها الكلى، والنتائج يوضـحها

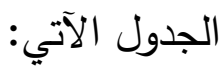




$$
\text { جدول (10) }
$$

نتائج اختبار ويلكوكسون وقيمة (Z) لدلالة الفروق بين متوسطي رتب درجات

أطفال المجموعة التجريبية في القياسين البعدي والتتبعي لأبعاد التنظيم الذاتي ومجموعها الكلى (ن=ه)

\begin{tabular}{|c|c|c|c|c|c|c|c|c|c|}
\hline مستوى الدلالة & $\begin{array}{l}\text { قيمة } \\
\text { "Z" }\end{array}$ & مجموع الرتب & متوسطات & | العدد & توزيع الرتب & الانحراف & الحستيط & القياس & المتغير \\
\hline \multirow{3}{*}{ غير } & \multirow[t]{3}{*}{ אזד. } & \multirow[t]{3}{*}{7} & \multirow[t]{3}{*}{$r$} & $r$ & الرتب السالبة & \multirow{3}{*}{$\begin{array}{l}\cdot v 1 \\
1 . r .\end{array}$} & \multirow{3}{*}{$\begin{array}{c}\text { YV } \\
\text { YY.r. }\end{array}$} & \multirow{3}{*}{ البتبدي } & \multirow[t]{3}{*}{ مراقبة الذات. } \\
\hline & & & & · & الرتب الموجبة & & & & \\
\hline & & & & r & الرتب المتعادلة & & & & \\
\hline \multirow{3}{*}{ غالة } & \multirow[t]{3}{*}{$1 . r \leqslant r$} & \multirow[t]{3}{*}{$r$} & \multirow[t]{3}{*}{1.0} & r & الرتب السالبة & \multirow{3}{*}{$\begin{array}{l}1 . \Sigma \Lambda \\
1 . r .\end{array}$} & \multirow{3}{*}{$\begin{array}{l}r \leq . \wedge . \\
r \varepsilon . r .\end{array}$} & \multirow{3}{*}{ البتبدي } & \multirow{3}{*}{ التخطيط } \\
\hline & & & & · & الرتب الموجبة & & & & \\
\hline & & & & $r$ & الرتب المتعادلة & & & & \\
\hline \multirow{3}{*}{ غير } & \multirow[t]{3}{*}{ } & \multirow{3}{*}{$\begin{array}{l}\text { v } \\
r\end{array}$} & \multirow{3}{*}{$\begin{array}{c}r . \mu r \\
r\end{array}$} & $r$ & الرتب السالبة & \multirow{3}{*}{$\begin{array}{l}. . \wedge r \\
r .11\end{array}$} & \multirow{3}{*}{$\begin{array}{l}\text { YV.A. } \\
\text { YV.r. }\end{array}$} & \multirow{3}{*}{ البتبدي } & \multirow{3}{*}{ السلوكي. } \\
\hline & & & & 1 & الرتب الموجبة & & & & \\
\hline & & & & 1 & الرتب المتعادلة & & & & \\
\hline \multirow{3}{*}{ غير } & \multirow[t]{3}{*}{$1 . r \leqslant r$} & \multirow{3}{*}{ r } & \multirow{3}{*}{$\begin{array}{l}. \\
1.0\end{array}$} & $\cdot$ & الرتب السالبة & \multirow{3}{*}{$\begin{array}{l}1 . A Y \\
1.7 V\end{array}$} & \multirow{3}{*}{$\begin{array}{l}\text { r..T. } \\
\text { r..T. }\end{array}$} & \multirow{3}{*}{ البتبدي } & \multirow[t]{3}{*}{ تقويم الذات. } \\
\hline & & & & r & الرتب الموجبة & & & & \\
\hline & & & & $r$ & الرتب المتعادلة & & & & \\
\hline
\end{tabular}




\section{كلية التربية للطفولة المبكرة- جامعة بني سويف}

\begin{tabular}{|c|c|c|c|c|c|c|c|c|c|}
\hline \multirow{3}{*}{ غير } & \multirow[t]{3}{*}{.941} & $V .0$ & r.o & r & الرتب السالبة & \multirow{3}{*}{$\begin{array}{l}1 . r . \\
r . \wedge 7\end{array}$} & \multirow{3}{*}{$\begin{array}{c}1.1 . r \\
. \\
1 . . r\end{array}$} & \multirow{3}{*}{ التبعدي } & \multirow{3}{*}{ الأبعاد التظيم الكلى } \\
\hline & & \multirow[t]{2}{*}{ Y.O } & \multirow[t]{2}{*}{ Y.O } & 1 & الات ت المهدي & & & & \\
\hline & & & & 1 & الرتب المتعادلة & & & & \\
\hline
\end{tabular}

يتضح من الجدول السابق أنهلا توجد فروق دالة إحصائياً عند مستوى دلالة (0...) بين متوسطي رتب درجات أطفال المجموعة التجريبية في القياسين البعدي والتتبعي لأبعاد التنظيم الذاتي (مراقبة الذات- التخطيط ووضـع الأهداف- التنظيم السلوكي- تقويم الذات) ومجموعها الكلي.

ويوضـح الثـكل الآتـي الأعمدة البيانيـة لمتوسطي درجـات أطفـال المجموعـة التجريبيـة في القياسين البعدي والتتبعي لأبعاد التنظيم الذاتي ومجموعها الكلى.

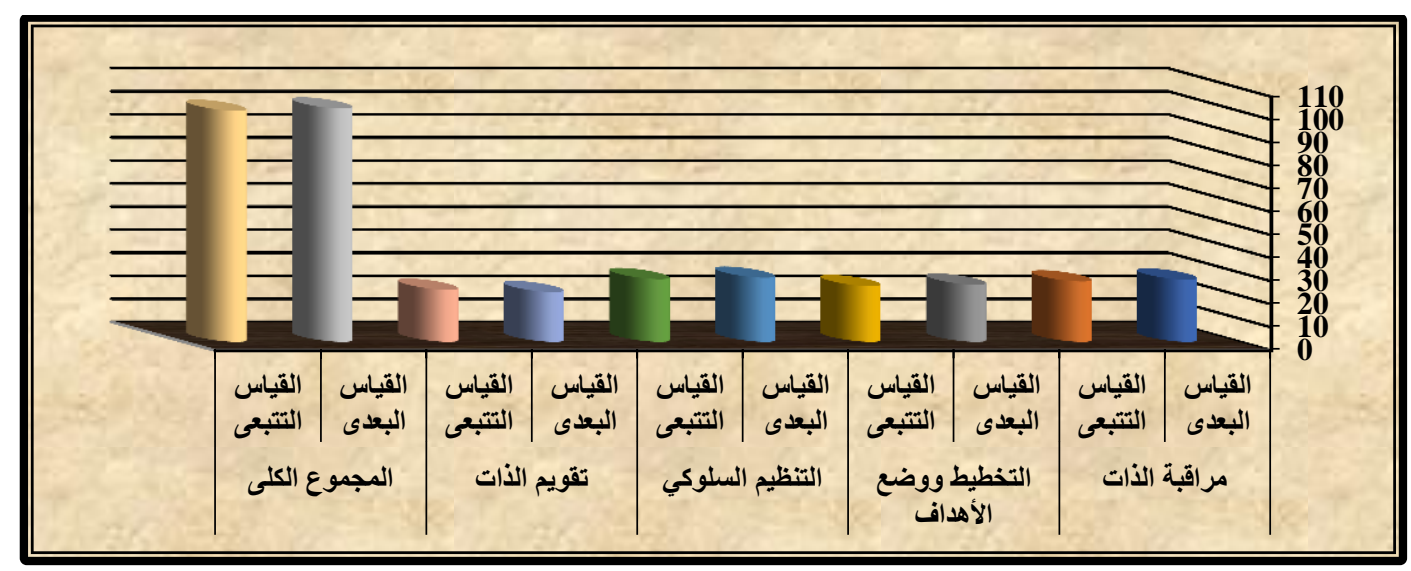

شكل (飞)

الأعمدة البيانية لمتوسطي درجات أطفال المجموعة التجريبية في القياسين البعدي والتتبعي لأبعاد التتظيم

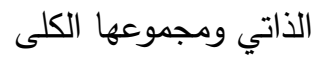




\section{مناقشة النتائج وتقسيرهـا}

أسفرت نتائج الدراسة الحالية عن تحقق صحة الفروض التي افترضتها الباحثتان حيث

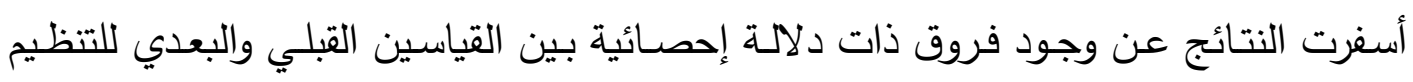
الذاتي لاى أطفال المجموعة التجريبية ذوى صعوبات التعلم في اتجاه القياس البعدي نتيجة

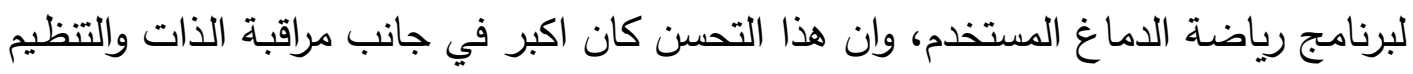

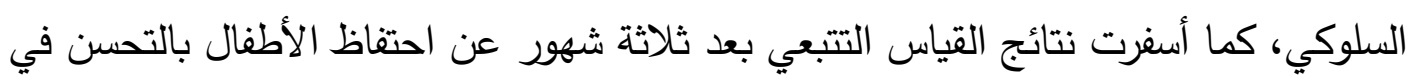

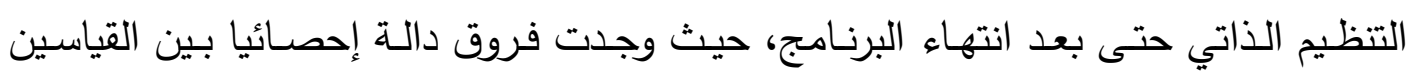

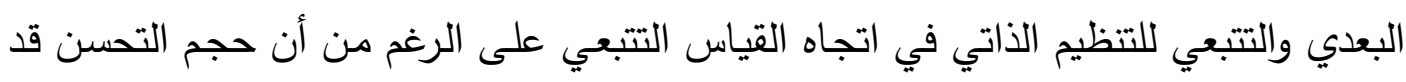
تناقص بشكل طفيف في القياس التتبعي، إلا أن حجم التأثير بقى في نطاق يعد قويا جداء التيا،

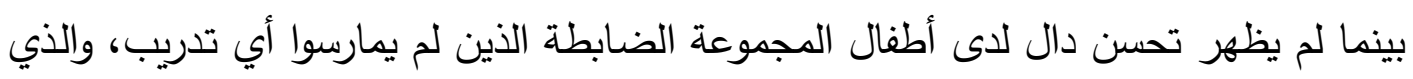

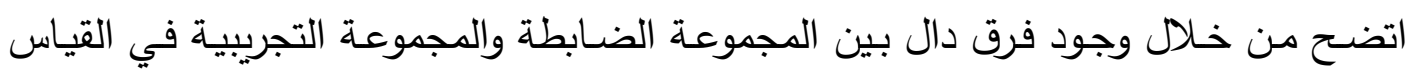
البعدي للتنظيم الذاتي لصالح المجموعة التجريبية.

وقد جاءت هذه النتيجة متفقة مع نتائج العديد من الدراسات والتي توصلت نتائجها إلى

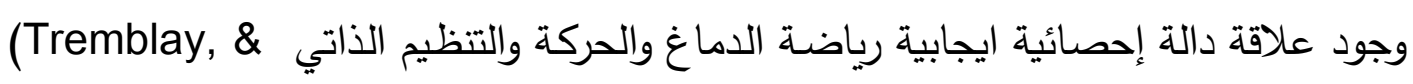
Williams, 2000; Kubesch, et al, 2009; Epema, 2010; Miller, 2010;

.Kolovelonis, 2011)

ويمكن تفسير ذلك في ضوء ما تسهم به رياضـة الدماغ في تدريب الطفل على كيفية

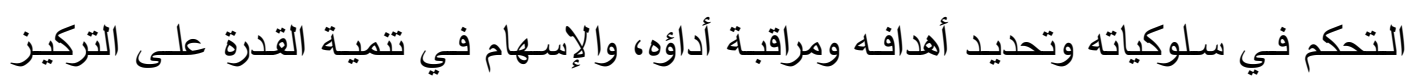
والانتباه وكل هذا ينعكس ايجابيا على مستوى التنظيم الذاتي. ومن هذه الدراسات نتائج دراسة

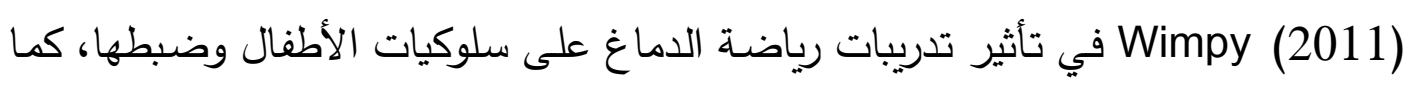
67

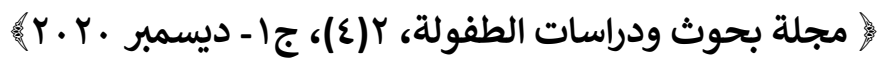




\section{كلية التربية للطفولة المبكرة- جامعة بني سويف}

أشارت الدراسة إلى أن تدريبات رياضة الدماغ تعد احد استراتيجيات التخخل المبكر، أي يمكن التأثير في سلوكيات الأطفال وتحسينها في مرحلة الطفولة المبكرة، وهو ما قامت به الدراسة الحاليـة في تحسين التظظيم الذاتي للأطفـال من مراقبة الذات، والتخطيط ووضـع الأهداف والتنظيم السلوكي والتقويم الذاتي. كما تتضـح العلاقة بين رياضـة الدماغ والتنظيم الذاتي من خلال ما أظهرت نتائج الدراسة الحالية دور رياضـة الدماغ في التتظيم الذاتي وإدارة السلوك (Peterson, 2002; ما يؤثر على الناحية الأكاديمية وهذا مـا أكدت علية كل من Wolfsont, 2002; Thirry et al., 2016) صـحيح ومتسق تعمل على التخفيف مـن التوتر والغضـب والإحباط وإدارة السـلوك وزيـادة الايجابيـة ممـا يسـاعد على تعزيز لتنظيم الذاتي.حيث أن تدريبات رياضــة الدماغ تقلل مـن الاضطرابات السلوكية الموجودة في غرفة التعلم التي تؤثر على المهام الأكاديمية، فرياضـة الدماغ إستراتجية لتعزيز السلوك الايجابي من خلال زيادة الوعي الذاتي وتعزيز الانضباط الذاتي مما يؤثر على تحسين الناحية الأكاديمية.

كمـا أوضـحت نتـائج الدراسـة الحاليـة أن لرياضــة الـدماغ ادوار تسـاعد الأطفـال على التنظيم الذاتي، فهي تساعد الأطفال على التفكير بهدوء، و تحضير وتجهيز الدماغ، حيث أن الطريقة التي يفكر ويتعلم بها الأطفال تتأثر بشكل مباشر بالنشاط الجسدي، كما أنها تعمل على تهدئة المـخ ممـا يسـاعد على تتشيط الأطفال واستعادة انتباههم وتركيزهم وتعزز مـن قدرتهم على التعلم، كما انها يمكن استيعاب الكثير من المعلومات وتتشيط الذاكرة، وهو ما يساعد الأطفال على تتظيم ذواتهم، فاستخدام الحركة في التعامل مـع الأطفال والتدريس بها يشكل جسور تربط بين الجسم والدماغ، فالأطفال يتذكرون المفـاهيم لفترات أطول عندما يتحركون، فتدريبات رياضـة الدماغ تجعل عملية التعلم أكثر كفاءة حيث أنها تشرك الدماغ بأكمله لفهم المفاهيم مما يجعلها من الاستراتيجيات التي تعزز البيئة التعليميـة التي تساعد على التنظيم الذاتي (Lengel, Kuczala, 2010; Kolovelonis, et al, 2011; Flatin, 2012.) 
Sمousand, 2008; كما تتفق نتائج الدراسة الحالية مع نتائج دراسة كل من Mantague, 2008; McFarland, 2009; Clarebout, 2010; Labuhn, Zimmerman 2010; Stoeger, 2011; De Corte, 2011; Wigfield, 2011) والتي أشارت نتائجها إلى أن تحسين التنظيم الذاتي لدى الأطفال ذوى صعوبات التعلم، الناتج

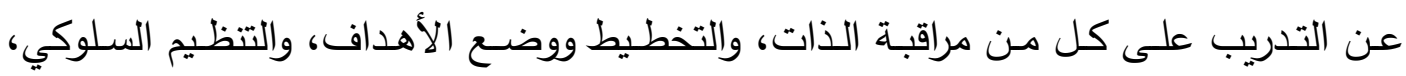
ومراقبة الذات، قد أدى إلى خفض أعراض صعوبات التعلم لديهم، فقد اظهر التقييم تحسن

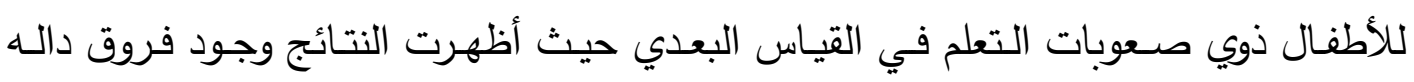
إحصائيا بين متوسطي رتب درجات الهجموعة التجريبية في القياسين القبلي والبعدي للأطفال

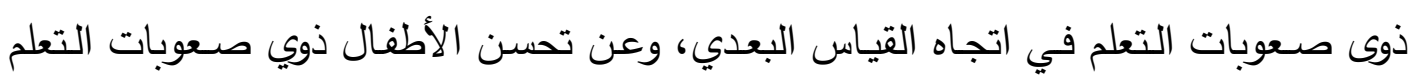
نتيجة تحسن التتظيم الذاتي بالتدريب عليه عنها للى المجموعة الضـابطة، حيث أظهرت النتائج وجود فروق دالة إحصائيا بين متوسطي رتب درجات المجموعتين الضابطة والتجريبية

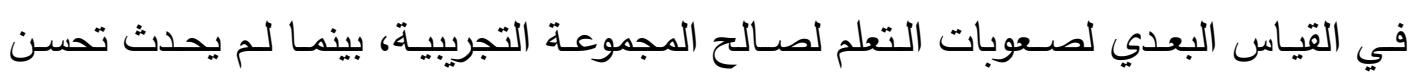

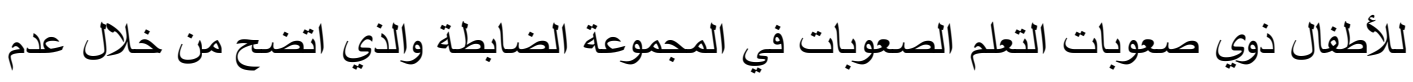
وجود فروق دالة إحصائيا بين متوسطي رتب درجات أطفال الهموعة الضابطة في القياسين القبلي والبعدي لصعوبات التعلم، مما يدعم الافتراض بتأثير تحسن التتظيم الذاتي لدى أطفال

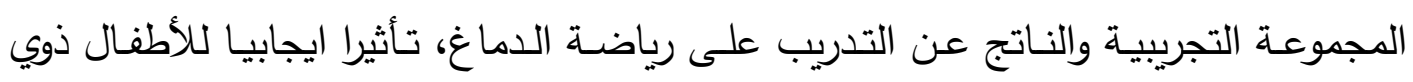
صعوبات التعلم لديهج بينما لم يحدث لاى أطفال المجموعة الضابطة.

ويمكن تنسير النتائج الايجابية إلى نتيجة تدريبات رياضة الدماغ في تحسين التظظيم

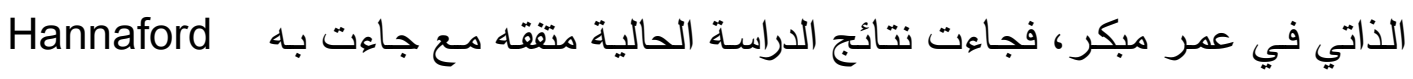
(2005) في التأكيد على دور تدريبات رياضة الدماغ في الحد من أعراض صعوبات التعلم

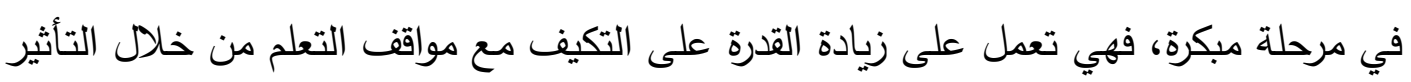
69

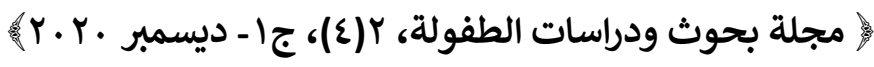




\section{كلية التربية للطفولة المبكرة- جامعة بني سويف}

الايجابي على سلوك الأطفال، كما أن تدريبات رياضـة الدماغ وسيلة لتعزيز وقت الطفل في المهام والأنشطة المختلفة كما تعمل على خلق متعلمين ايجابيين وحيويين، فالدماغ البشرى يحتاج إلى أكسجين وماء لاعم التفكير في عملية التعلم، حيث أن معرفة وتوازن نشاط فصي الدماغ الأيمن والأيسر يزيد من الدافعية للتعلم ومن القدرة على التحكم في التصرفات الذاتية مما قد يعزز الوعي بالذات ويحفز الأطفال ويخفض المشكلات السلوكية وهذا ما يحتاج إلية الأطفال ذوى صعوبات التعلم. وفى هذا الصدد جاءت نتائج الدراسـة الحالية متفقة مـع مـا توصلت إلية دراسة (2012) .Ursache et al إلى التأكيد على أهمية تدريب الأطفال على التنظيم الذاتي في عمر مبكر، حيث يعمل هذا التدريب على تحسين الكفاءة الأكاديميـة وتطوير الجوانب المعرفيـة، وتطوير الذات أيضـا، كمـا أنها تعمل على زيـادة الدافعيـة لدى الأطفال، وتتميـة الإدراك كما تعمل على تطوير علاقة تبادلية بين التفكير والسلوك، وهذا يساعد الأطفال ذوى صعوبات.

ويمكن عزو تلك النتائج إلى أن الدراسة اعتمدت في تجربتها على برنامج تم اختبار تأثيره في دراسـات عديدة أشـارت نتائجها إلى دور تدريبات رياضــة الـدماغ في الحـد مـن صعوبات التعلم عن طريق زيادة الروابط العصبية ووظائف الانتباه وإيقاظ الوظائف الحسية

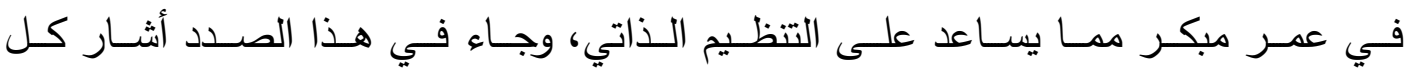
(Hannaford, 2005; Kubesch, et al, 2009; McFarland, et al, 2009) من التي أثارت إلى بعض النقاط التي تعزز هذه النتائج، حيث ترتبط عملية التعلم بعمل القشرة المخية، كما تتطور وتنمو الروابط العصبية للأطفال الذين يشاركون في تجارب خصبة وغنية مثل رياضة الدماغ في عمر مبكر ، ويتقق ذلك مع طبيعة ما تحققه تدريبات رياضـة الدماغ من تتشيط وظائف الدماغ بشكل متكامل ليس ذلك وفقط بل يعمل على الاتصـال الجيد بين الجسم والعقل، مما يعمل على إيقاظ النشاط العقلي وتحفيز الاستعداد للتعلم، وهو ما يحتاج إلية الأطفال ذوى صعوبات التعلم، كما تركز تدريبات رياضـة الدماغ أيضـا على الوظائف 
الحسية، كما تزيد من تدفق الدم إلى المـخ مما يساعد على تتشيط العضلات وتجهيز الدماغ

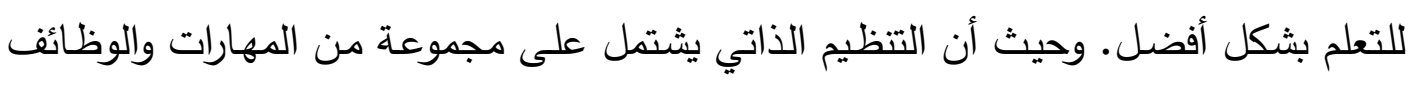

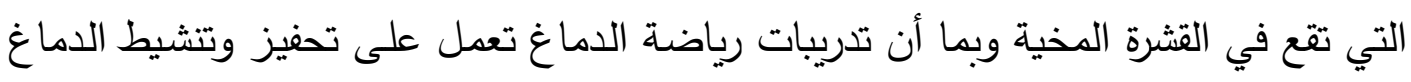

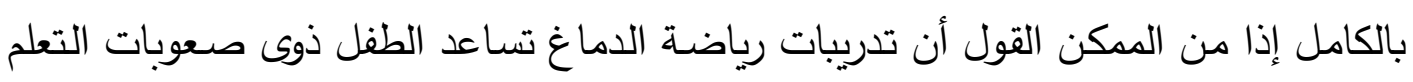
على التتظيم الذاتي.

كما يمكن تفسير نجاح تجربة البحث الحالي في ضوء وجهه النظر التي تثير إلى دور

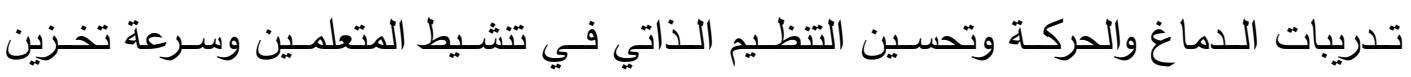
المعلومات وتتشيط الانتباه والذاكرة وتعزيز القدرة على التعلم وتحسين الإنجاز الأكاديمي كما لهابـ

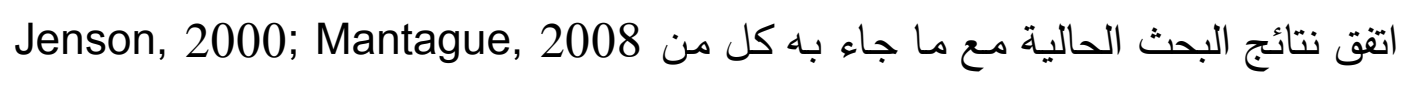
Jيث أشاروا إلى أن لـenson, 2007; Lengel, 2010; (Kenney Comizio, 2016) هناك اتصالات وتبادلات بين الجسم والدماغ، وان للحركة أهميه بالغة في تحسين التنظيم

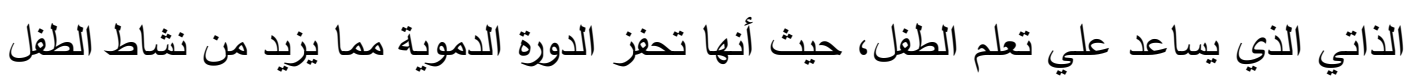

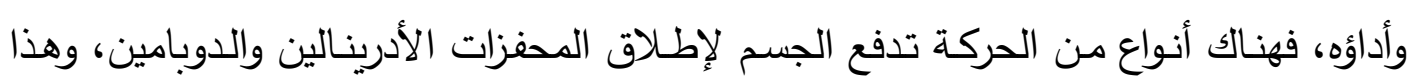

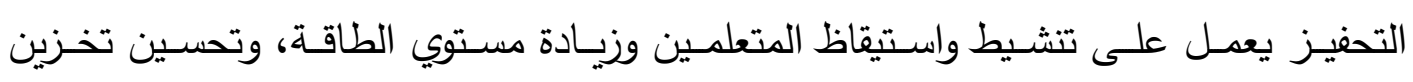

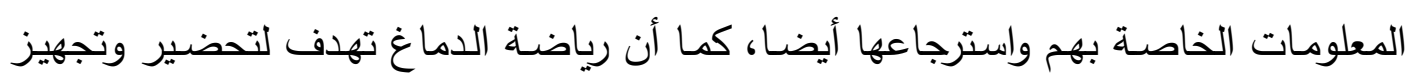

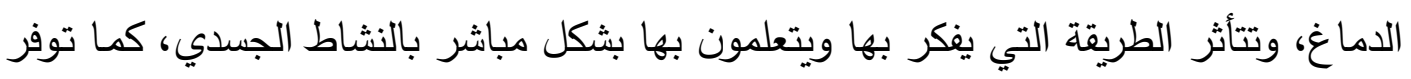

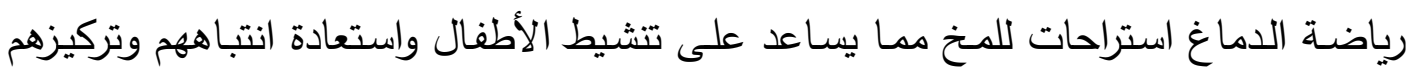
وتحسين مراقبة الذات ووضع الأهداف بصوره خاصة والتتظيم الذاتي بصورة عامة، وتعزز من قدرتهم على التعلم، مما يساعد على استيعاب الكثير من المعلومات وتتثيط الذاكرة. وتعـد احدي العوامـل التـي تــزز دور تـدريبات رياضــة الـدماغ الايجابيـة استهلال

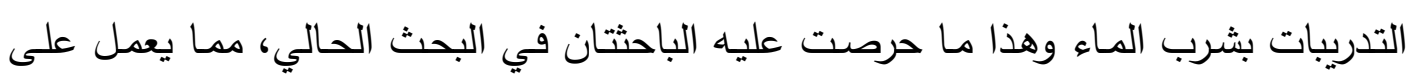
71

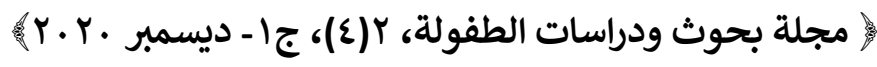




\section{كلية التربية للطفولة المبكرة- جامعة بني سويف}

(Jenson, 2000; الحفاظ على الحيوية والنشاط وزيادة طاقة الجسم، حيت أشارت الأبحاث (إلـي أهميـة شرب المـاء، فيعتبر نقص المـاء السبب الرئيسي للثعور بالتعب خلال النهار ، ويمكن أن يتسبب انخفاض الماء في الجسم في التأثير على التحصيل الأكـاديمي، فيؤثر على الذاكرة قصيرة المـدى والمهارات القرائيـة على سبيل المثال. ومـن العوامل التي ساعدت على نجاح البرنامج الحالي لدى المجموعة التجريبية صغر حجم العينة، وكونها مناسبة لإيجاد الفرصـة لكل منهم لممارسـة تدرببات البرنامج بصوره فردية وجماعية ايجابية، وتقديم التغذية الراجعة له إذا لزم الأمر ، وقد ساعد على نجاح على نجاح ذلك عدم وجود فترات طويلة فاصلة بين الجلسات، فقد كانت مستمرة بشكل يومي، مما يساعد على تحسين التنظيم الذاتي لدى الأطفال ذوى صعوبات التعلم وهذا مـا اتضـح من خـلال أدائهم على مقياس التظيم الذاتي بعد تطبيق البرنامج. كما جاءت نتائج الدراسة الحالية متفقة مـع الدراسات السابقة في أن هناك علاقة تبادلية بين كل من التنظيم الذاتي والأداء الأكاديمي لاى الأطفـال ذوى صـعوبات الـتعلم، فكلمـا تحسـن التتظيم الـذاتي زاد ذلـك مـن تحسـين الأداء (Rock, 2005;Alferink, 2007; Wilkinson, 2008; الأكاديمي ومن هذه الدراسات .Jarvela \& Jarvenoja 2011; Wigfield, et al, 2011)

فزيـادة التنظيم الـذاتي تعمـل على زيـادة الثقــة بـالنفس وتقليـل المشكلات السـلوكية، فيتضمن برنـامج رياضـة الدماغ تدريبات تعمل على زيـادة التحكم الذاتي والثقة بالنفس، مما يساعد الأطفال على الاستقلالية فتزيد مهارات التتظيم الذاتي، مما يؤثر ايجابيا على الأداء الأكاديمي، وذلك من خـلال الانخراط في أنشطة رياضـة الدماغ بطريقة ايجابيـة.كما أكدت دراسة (2018) أن التدريب علي التنظيم الذاتي يزيد من مناخ التعلم الإيجابي والتعامل مع بيئات تعلم مختلفة فالأطفال الذين يتلقون تدريب علي مهارات مراقبة الذات والتخطيط أكثر احتمالا للحصول علي مستويات اعلي من الكفاءة الذاتية الأكاديمية والثقة بالنفس والأداء. 


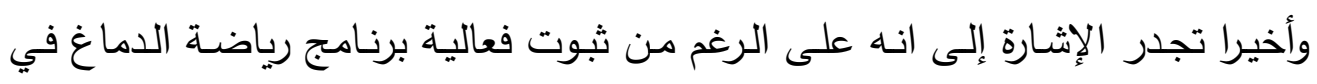

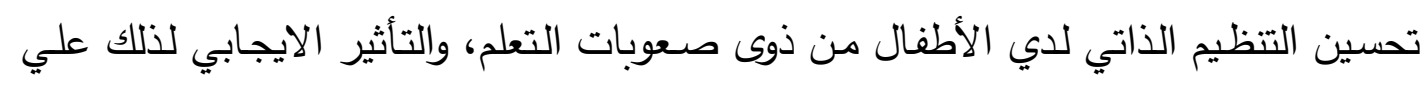

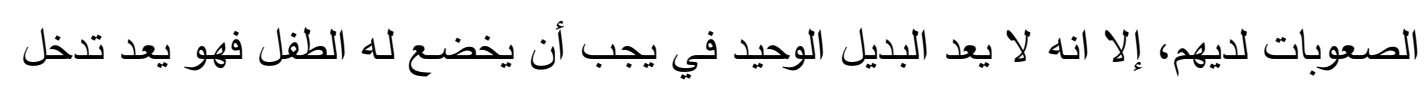

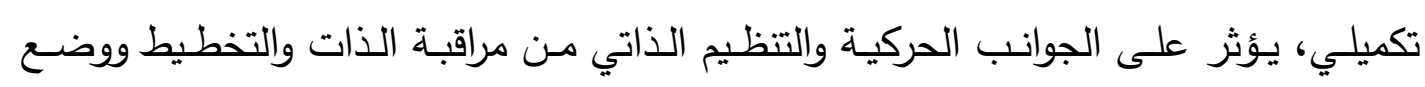

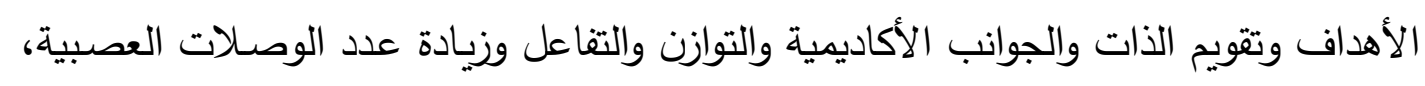

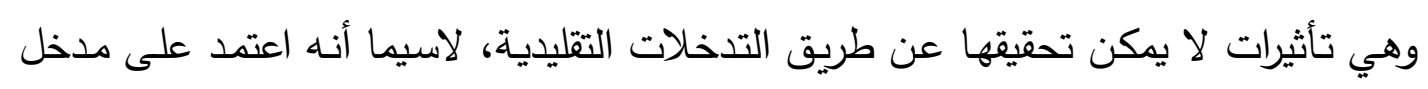
الحركة وهو مدخل محبب ومفضل للأطفال.

\section{توصيات البحث}

في ضوء الإطار النظري والدراسات السابقة هناك مجموعة من التوصيات كما يلي: - الاهتمام بالتدل المبكر لتحسين التنظيم الذاتي وبالتالي خفض أعراض صعوبات التعلم. - توجيه نظر القائمين على العملية التعليمية وأولياء أمور الأطفال ذوى صعوبات التعلم إلى أهميه وفعالية برامج رياضة الدماغ لما لها من أهمية كبيرة للأطفال. - عقد دورات تدريبيه لمعلمي الأطفال ذوى صعوبات التعلم ومعلمي غرف المصادر على كيفيه تطبيق برنامج رياضة الدماغ واستراتيجياته المختلفة.

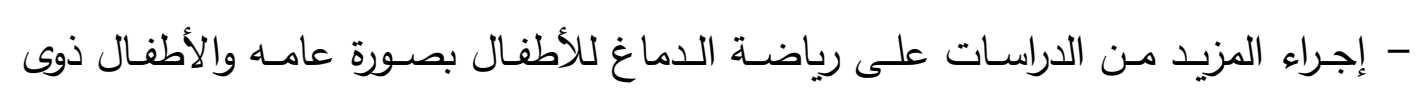
الاحتياجات الخاصة، على عينات مختلفة، للتخفيف من حدة المشكلات السلوكية.

- الاستعانة برنـامج رياضــة الـماغ للأطفـال ذوى صـوبات التعلم في العمليـة التربويـة

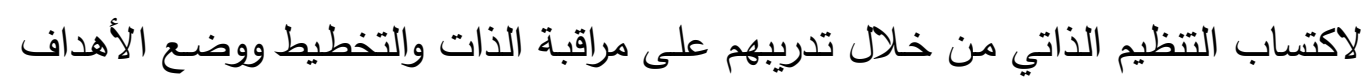
والتنظيم السلوكي وتقويم الذات مما ينعكس على التوافق والتفاعل مع البيئة الدحيطة. 


\section{المراجع}

\section{أولاً: المراجع العربية}

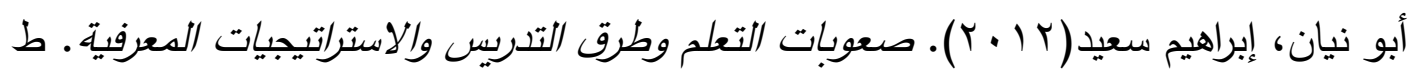
(r) الرياض: دار الناشر الدولي للنشر والتوزيع.

بشير، سعد زغلول (r. ..r). دليلك إلى البرنامج الإحصائي (SPSS). العراق- بغداد: منشورات المعهد العربي للتدريب والبحوث الإحصائية.

الخطيب، جمال، والحديدي، منى(Y ( ب).المدخل إلى التربية الخاصة. عمان: دار الفكر

$$
\text { العربي }
$$

ذكى، أمل عبد المحس (^ . ㄷ). أثر برنامج تدريبي قائم على بعض استراتيجيات التعلم المنظم ذاتيا في الدافعية والتحصيل الدراسي لدى عينة من التلاميذ ذوى صعوبات التعلم. رسالة دكتوراه غير منثورة، كلية التربية، جامعة بنها.

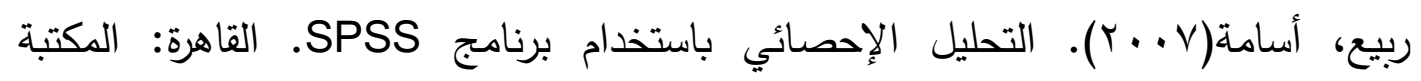
الأكاديمية.

الرمامنة، عبد اللطيف (9 ( ب). مستوى التنظيم الذاتي لدى الطلبة ذوى صعوبات العلم وعلاقته بالتحصيل الدراسي من وجهة نظر معلميهم في مدينة السلط. مجلة دراسات

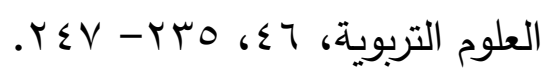

سالم، محمود ، و ذكي، أمل (· ( †). صعوبات التعلم بين النظرية والتطبيق. القاهرة:

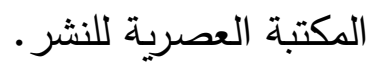

الشخص، عبد العزيز،و جارحي، سيد(11 +r). صعوبات التعلم الأكاديمية- الأساليب والبرامج التربوية والعلاجية. القاهرة: الطبري. 
عبيد، ماجدة(r + (Y). مقدمة في إرشاد ذوى الاحتياجات الخاصة وأسرهم. عمان: دار الصفاء للنشر والتوزيع.

علام، صلاح الدين محمود (·(ب). الأساليب الإحصائية الاستدلالية البارامترية واللابارامترية في تحليل بيانات البحوث النفسية والتربوية والاجتماعية. القاهرة: دار الفكر

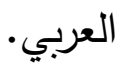

عواد، أحمد أحمد (11) (1). مدخل تثخيصي لصعوبات التعلم لاى الأطفال (اختبارات

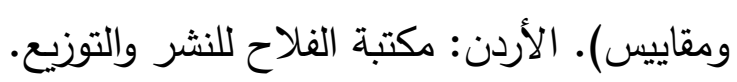

القاسم، جمال( .... (†). أساسيات صعوبات التعلم. عمان: دار صفاء للنشر والتوزيع.

مراد، صلاح( (1 • r). الأساليب الإحصائية في العلوم النفسية والتربوية والاجتماعية. القاهرة: مكتبة الأنجلو المصرية.

مصطفى، حسن(1 +. r). الاضطرابات النفسية في الطفولة والمراهقة: الأسبابالتثخيص - العلاج. القاهرة: مكتبة القاهرة للكتاب.

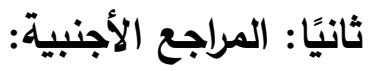

Alferink, L., (2007). Educational Practices- Superstitious Behavior and Mythed Opportunities. The Scientific Review of Mental Health Practice. 5(2). 21- 30.

American Psychiatric Association (2013). Diagnostic and Statical Manual of Mental Disorders. (5th ed). Arlington, VA: American Psychiatric Publishing.

Bandy, T.\&. Moore, K. (2010). Assessing Self- Regulation: A Guide for out - of- School Time Program Practitioners. Washington, DC. Retrieved from www.childtrends.org. 
Berninger, V.,\& Richards, T. (2009). Brain and Learning. in E. Anderman \& L.Anderman (Eds). Psychology of Classroom Learning: An Encyclopedia (Vol. 1, pp. 15- 22). Detroit: MacMillan Reference USA.

Bjork, R. A., Dunlosky, J., \& Kornell, N. (2013). Self- Regulated Learning: Beliefs, Techniques, and Illusions. Annual Review of Psychology. 64. 417- 444.

Brain Gym (2016). Educational Kinesiology Foundation. Retrieved November 6, 2016. From https: //breakthroughsinternational.org/programs/the- brain- gymprogram/

Brown, K.(2012). Educate Your Brain. Canada: Balance Point Publishing.

Butler, D. \&Schnellert, L. (2015). Success for Students with Learning Disabilities: What Does Self- Regulation Have to do With It? To Appear in T. Cleary (Ed.), Self- Regulated Learning Interventions with At- Risk Youth: Enhancing Adaptability, Performance, and Wellbeing. Chapter 5, Washington, DC: APA Press.

Clarebout, G., Horz, H., \& Schnotz, W. (2010). The Relations Between Self- Regulation and the Embedding of Support in Learning Environments. Educational Technology Research and Development, 58(5), 573- 587.

Cleary, T. J., \& Zimmerman, B. J. (2004). Self- Regulation Empowerment Program: A School- Based Program to Enhance Self- Regulated and Self- Motivated Cycles of Student Learning. Psychology in the Schools, 41, 537- 550.

Coch, D., Michlovitz, S., Ansari, D., \& Baird, A. (2009). Building Mind, Brain, and Education Connections: The View From the Upper Valley. Mind, Brain, and Education, 3 (1), 27- 33. 
Dawson, P\& Guare, R. (2009). Smart but Scattered The Revolutionary "Executive Skills" Approach to Helping Kids Reach Their Potential. New York: The Guilford Press.

De Corte, E., Mason, L., Depaepe, F., \&Verschaffel, L. (2011). SelfRegulation of Mathematical Knowledge and Skills. In B. J. Zimmerman, \& D. H. Schunk (Eds.), Handbook of SelfRegulation of Learning and Performance (pp. 155- 172). New York: Routledge.

Dembo. M. \& Seli. H. (2013). Motivation and Learning Strategies Success: a Focus on Self- Regulated Learning. (4th ed). New York: Taylor \& Francis Press.

Dennison, P. \& Dennison, G. (2010). Brain Gym: Teacher's. Ventura, CA Edu- Kinesthetics Inc.

Dennison, P. (2006). Brain Gym and Me- Reclaiming the Pleasure of Learning. Ventura, CA. Edu Kinesthetics.

Ellis, R.\& Newton, N. (2010). How the Mind Uses the Brain: To Move the Body and Image. The Universe. United States of America.

Epema, D. (2010). Movement in the Classroom: The Impact of Brain Gym Activities to Increase on- Task Behavior of Students Identified for Special Needs in an Integrated 1st grade Classroom. (Master's thesis). Available from ProQuest Dissertations and Theses database. (UMI No. 1485795).

Felver, J.(2013). Understanding Children's Self- Regulation: An Analysis of Measurement and Change in the Context of a Mindfulness- Based Intervention. Doctor of Philosophy. Department of Special Education and Clinical Sciences, University of Oregon, Eugene, OR. 
Field, A. (2009). Discovering Statistics Using SPSS. (3rded). London SAGE Publications Ltd.

Fischer, K. (2009). Mind, Brain and Education: Building a Scientific

Groundwork for Learning and Teaching. Mind, Brain, and Education, 3 (1), 3- 16.

Flatin, E(2012). Brain GYM In an Early Childhood Education Preschool Classroom. Master of Scince in Education. Southwest Minnesota State University.

Graham, L.\&Berman, J. (2012). Self- Regulation and Learning Disabilities. Special Education Perspective, 21(2), 41- 52.

Greene, J. A. (2018). Self- Regulation in Education. New York: Routledge.

Greene, J., Deekens, V., Copeland, D., \& Yu, S. (2018). Capturing and Modeling Self- Regulated Learning Using Think- Aloud Protocols. In D. H. Schunk \& J. A. Greene (Eds.), Educational Psychology Handbook Series. Handbook of Self- Regulation of Learning and Performance (p. 323- 337). Routledge/Taylor \& Francis Group.

Gross, J. \&Thompson, A.(2007). Emotion Regulation Conceptual Foundation. In J.J. Gross(Ed), Handbook of Emotion Regulation (pp.3-24). NewYork: Guilford Press.

Hallahan, D., Kauffman, J., \& Pullen, P. (2018). Exceptional Learners: An Introduction to Special Education. (14th ed). USA: Pearson Education.

Hannaford, C. (2005). Smart Moves; Why Learning is Not All in Your Head. (2nd ed).Arlington, VA: Great Ocean Publishers, Inc.

Hannaford, C.(2011). The Dominance Factor: How Knowing Your Dominant Eye, Ear, Brain, Hand \& Foot Can Improve Your Learning(2nded).Library of Congres: Great River Book. 
Housand, A.\& Reis, S.(2008). Self Regulated Learning in Reading Pedagogy and Instructional Setting. Journal of Advanced Academic, 20 (1), 108- 136.

Howard- Jones, P. (2007). Neuroscience and Education: Issues and Opportunities. Retrieved from Teaching \& Learning Research Program website: http:

//www.tlrp.org/pub/documents/Neuroscience\%20Commentary \%20FINAL.

Hurk, M. (2006). The Relation Between Self- Regulated Strategies and Individual Study Time, Prepared Participation and Achievement in a Problem Based Curriculum. Active Learning in Higher Education, 7(2), 155- 169.

Hyatt, K. (2007). Brain Gym: Building Stronger Brains or Wishful Thinking? Remedial and Special Education, 04(2), 117- 124.

Jarvela, S., \&Jarvenoja, H. (2011). Socially Constructed SelfRegulated Learning and Motivation Regulation in Collaborative Learning Groups. Teachers College Record, 113(2), 350- 374.

Jensen, E. (2007). Introduction to Brain- Compatible Learning. (2nd ed). United State: Corwin press Sage Publication Company.

Jenson, E.(2000). Moving with the Brain in Mind Educational Leadership. The Science of Learning, 58(3). 34- 37.

Johnston, P; Wilkinson, K (2009). Enhancing Validity of Critical Tasks Selected for College and University Program Portfolios. National Forum of Teacher Education Journal, 19 (3), 1- 6.

Kenney, L.\& Comizio, R. (2016). 70 Play Activities for Better Thinking, Self- Regulation, Learning \& Behavior. United States of America: PESI Publishing \& Media. 
kirk, S., Gallager, J., Coleman. M., \&Anastaiow, N. (2013). Education Exceptional Children. USA: wadsWorthcengage learning.

Klassen. R. (2010). Confidence To Manage Learning: The SelfEfficacy For Self- Regulated Learning Of Early Adolescents With Learning Disabilities. Learning Disability Quarterly, 33, 19- 30.

Kolovelonis, A., Goudas, M., \& Dermitzaki, I. (2011). The Effect of Different Goals and Self- Recording on Self- Regulation of Learning a Motor Skill in a Physical Education Setting. Learning and Instruction, 21 (3), 355- 364.

Kubesch, S., Walk, L., Spitzer, M., Kammer, T., Lainburg, A., Heim, R.,\& Hille, K., (2009). A 30- Minute Physical Education Program Improves Students' Executive Attention. Mind, Brain, and Education, 1(4), 235- 242.

Labuhn, A., Zimmerman, B., \& Hasselhorn, M. (2010). Enhancing Students' Self- Regulation and Mathematics Performance: The Influence of Metacognition and Learning, 5 (2), 173- 194.

Lakes, K. \& Hoyt, W. (2004). Promoting Self- Regulation Through School- Based Martial Arts Training. Journal of Applied Developmental Psychology, 25(3), 283- 302.

Lane, K., Harris, K. R., Graham, S., Weisenbach, J., Brindle, M., \& Morphy, P. (2008). The Effects of Self- Regulated Strategy Development on the Writing Performance of Second Grade Students with Behavioral and Writing Difficulties. Journal of Special Education, 41(4), 234- 253.

Lengel, T. \&Kuczala, M. (2010). The Kinesthetic Classroom:

Teaching and Learning Through Movement. Thousand Oaks, CA: Corwin.

Lens, W., \& Vansteenkiste, M. (2008). Promoting Self- Regulated Learning: A Motivational Analysis. In D. H. Schunk \& B. J. 
Zimmerman (Eds.), Motivation and Self- Regulated Learning: Theory, Research, and applications (pp. 141- 168). New York: Erlbaum.

Leyva, D.\&Nolivos, V.(2015). Children Family Reminiscing About Emotions and its Relation to Children's Self_Regulation Skills. Early Education and Development, 26, 776- 791.

McFarland, L., Saunders, R., \& Allen, S. (2009). Reflective Practice and Self- Evaluation in Learning Positive Guidance: Experiences of Early Childhood Practicum Students. Early Childhood Education Journal, 36(6), 505- 511.

Miller, D.\&Robertson, D.(2010). Using a Games Console in the Primary Classroom: Effects of 'Brain Training' Programme on Computation and Self- Esteem. British Journal of Educational Technology, (2), 242- 255.

Milligan, K., Badali, P. \& Spioiu, F.(2015). Using Itegra Mindfulness Martial Arts to Address Self_Regulation Challenges in Youth With Learning Disabilities: AQualitative Exploration. Journal of Child and Family Studies, 24, 562- 575.

Mithaug, D.(2002). Teaching Children With Multiple Disabilities to Self- Regulate During Independent Work. Teaching Exceptional Children, 35(1), 22- 27.

Moilanen, L. (2007). The Adolescent Self Regulation Inventory: The Development and Validation of a Questionnaire of Short- Term and Long Term Self- Regulation. Journal of Youth and Adolesscance, 36, 835- 848.

Montague, M. (2008). Self- Regulation Strategies to Improve Mathematical Problem- Solving for Students with Learning Disabilities. Learning Disability Quarterly, 31, 37- 44. 
Monteriro, M.(2015). The Impact of a Mindfulness Based Attentional Skills Training Program on School Related Self- Regulation Skills of Elementary School Children. College of Education, PHD Texas A\&M University- Corpus Christi.

National Research Center on Learning Disabilities (NRCLD) (2013). And Miles to Go: State SLD Requirements and Authoritative Recommendations. DownloadedSeptember28, 2013from: http: //www.nrcld.org/about/ research/states/section4.html.

Official Brain Gym Web Site. (2009). Retrieved February, 16, 2011, from http: //braingym.org/.

Panadero, E., Klug, J., \& Järvelä, S. (2016). Third Wave of Measurement in the Self- Regulated Learning Field: When Measurement and Intervention Come Hand in Hand. Scandinavian Journal of Educational Research, 60, 723- 735.

Pederson, J.(2008). ADHD and Brain Gym. Office of State Superintends of Public Instruction, SpecialEducation, http: //www.newnonizons.org.

Peterson, K. (2002). Brain Gym Intergenerational Mentoring Program Improves Reading and Decreases Problem Behaviors. Brain Gym International.

Reid, R., Harris, K., Graham, S., \& Rock, M. (2012). Self- Regulation Among Students with LD and ADHD. In Wong \& Butler, Learning About Learning Disabilities (4th ed). (pp. 141- 173) Elsevier Academic Press.

Reynolds, C., Vannest .\& Fletcher-Janzen, E. (2014). Encyclopedia of Special Education: A Reference for the Education of Children, Adolescents, and Adults with Disabilities and Other Exceptional Individuals., Vol. 1: E- O, (4th ed). Hoboken, NJ, US: Wiley Publishing. 
Rice. M. \&Carter, R. (2016). Online Teacher Work to Support SelfRegulation of Learning in Students with Disabilities at a Fully Online State Virtual School, Online Learning, 20 (4), 118- 135

Rock, M. (2005). Use of Strategic Self- Monitoring to Enhance Academic Engagement, Productivity, and Accuracy of Students with and Without Disabilities. Journal of Positive Behavior Interventions, 7, 3- 17.

Roll, I., \& Winne, P. H. (2015). Understanding, Evaluating, and Supporting Self- Regulated Learning Using Learning Analytics. Journal of Learning Analytics, 2(1), 7- 12.

Santangelo, T., Harris, K.\& Graham, S. (2007). Self- Regulated Strategy Development: A Validated Model to Support Students who Struggle with Writing. Learning Disabilities. A Contemporary Journal, 5(1), 1- 20.

Spaulding, L., Mostert, M., \& Beam, A. (2010). Is brain Gym® an Effective Educational Intervention?. Exceptionality, 75(1), 18- 30.

Stephenson, J. (2009). Best Practice? Advice Provided to Teachers About the Use of Brain Gym in Australian Schools. Australian Journal of Education, 53(2), 109- 124.

Stoeger, H., \& Ziegler, A. (2011). Self- Regulatory Training Through Elementary- School Students' Homework Completion. In B. J. Zimmerman, \& D. H. Schunk (Eds.), Handbook of SelfRegulation of Learning and Performance (pp. 87- 101). New York: Routledge.

Thirry, K., Bryant, H., Nobles, S., \&Norris. (2016). Tow Years Impact of Mindfulness- Based Program on Preschooler SelfRegulation and Academic Performance. Early Education and Development, 27(6), 805-821. 
Thornton, V., Williamson, R., \&Cooke, B. (2017). AmindfulnessBased Group for Young People with Learning Disabilities: ApilotStudy. British Journal of Learning Disabilities, 45, 259- 265.

Tremarche, P., Robinson, E., \& Graham, L. (2007). Physical Education and its Effect on Elementary Testing Results. Physical Educator, 64(2), 58- 64.

Tremblay, J., Inman, J., \& Williams, J. (2000). The Relationship Between Physical Activity, Self- Esteem, and Academic Achievement in 12- Year Old Children. Pediatric Exercise Science, 12, 312- 323 .

Trentacosta, C., \& Shaw, D. (2009). Emotional Self- Regulation, Peer Rejection, and Anti- Social Behavior: Developmental Associations from Early Childhood to Early Adolescence. Journal of Applied Developmental Psychology, 30(3), 356- 65.

Tuncay, T.(2019). The Effect of Self- Regulation Based Strategic Reading Education on Comprehension, Motivation, and SelfRegulation Skills. International Journal of Progressive Education, 15 (4) $27-46$.

Ursache, A., Blair, C., \&Raver, C. (2012). The Promotion of Self_Regulation as ameans of enhancing School Readiness and early Achievement in Children at Risk for school Failure. Child Development Perspective, 6, 122- 128.

Viglas, M.\&Perlaman, M. (2018). Effects of A Mindfulness- Based Program on Young Children's Self- Regulation prosocial Behavior and Hyperactivities. Journal of Child and Family Studies. 27, 1150- 1161.

Wigfield, A., Klauda, S., \& Cambria, J. (2011). Influences on the Development of Academic Self- Regulatory Processes. In B. J. Zimmerman, \& D. H. Schunk (Eds.), Handbook of self- Regulation of Learning and Performance (pp.33-48). New York: Routledge. 
Wilkinson, L. (2008). Self- Management for Children with HighFunctioning Autism Spectrum Disorders. Intervention in School and Clinic. 43(3), 150- 157.

Wimpy, J. (2011). The Effects of Brain Gym on Student Behavior. PHD, Walden University.

Wolfsont, C. (2002). Increasing Behavioral Skills and level of Understanding in adults.ABrief Method Integrating Dennison's Brain Gym Balance With Piaget's Reflective Processes. Journal of Adult Development, 9(3), 187- 203.

Wong, B. \& Butler, D. (2012). Learning About Learning Disabilities. (4th ed.). Elsevier Academic Press.

Yamada. M., Oi.M., \&Konomi, S, (2017). Are Learning Logs Related To Procrastination? From The Viewpoint Of Self- Regulated Learning. 14th International Conference on Cognition and Exploratory Learning in Digital Age.

Zimmerman, B. \& Schunk, D. (2011). Handbook of Self- Regulation of Learning and Performance. New York: Routledge.

Zimmerman, B.(2000). Attaining Self- Regulation: A Social Cognitive Perspective. In. M. Boekaertis, P, R\&M. Zeidner (EDs), Handbook of Self- Regulation: Theory, Research, and Applications. (pp.13- 39). san Diego: Academie.

Zimmerman, B., \& Cleary, T. (2009). Motives to Self- Regulate Learning: A Social Cognitive Account. In K. R. Wentzel \& A. Wigfield (Eds.), IN Handbook of Motivation at School (pp. 247264). New York: Routledge.

Zimmerman, J. (2008). Investigating Self-Regulation and Motivation. Historical Back Ground Methodological Developments and Future Prospects. American Educational Research Jouranal, 45(1), 166184. 


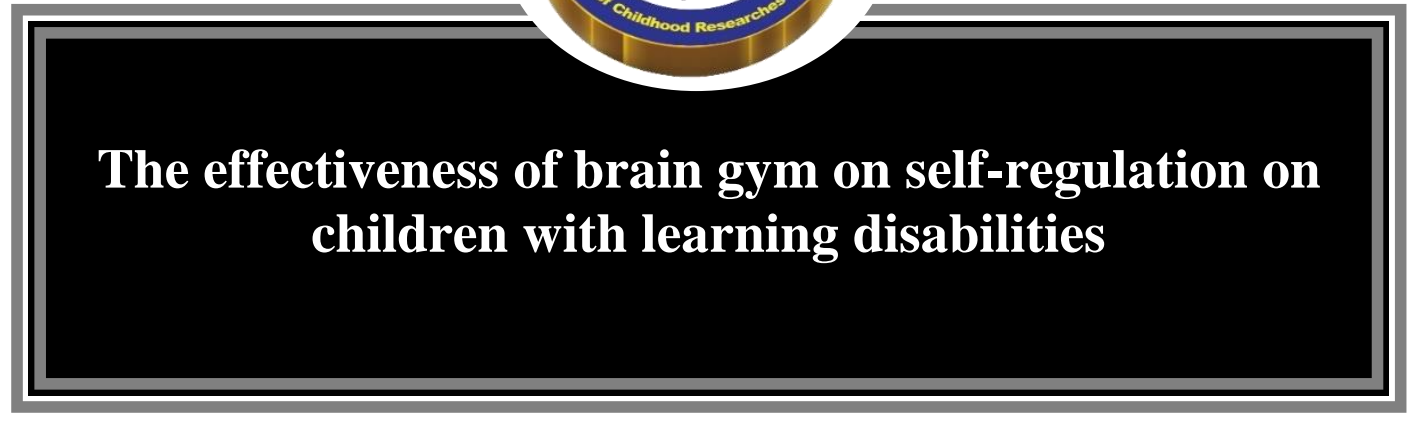

\section{Prepare:}

\section{Ola Mohamed Zaki El Taibani}

Associate Professor -Psychological Sciences Department - Early childhood Education Faculty- Alexandria University

\section{Nashwa Abdelhamid Younis}

Lecturer, Basic Sciences Department Early childhood

Education Faculty- Alexandria University 